\title{
Mind the body : omtrent omgang met lichamelijke klachten en ziekten bij chronische patienten in een sociaal psychiatrische praktijk
}

Citation for published version (APA):

Honig, A. (1989). Mind the body : omtrent omgang met lichamelijke klachten en ziekten bij chronische patienten in een sociaal psychiatrische praktijk. [Doctoral Thesis, Maastricht University]. Rijksuniversiteit Limburg. https://doi.org/10.26481/dis.19891208ah

Document status and date:

Published: 01/01/1989

DOI:

10.26481/dis.19891208ah

Document Version:

Publisher's PDF, also known as Version of record

Please check the document version of this publication:

- A submitted manuscript is the version of the article upon submission and before peer-review. There can be important differences between the submitted version and the official published version of record.

People interested in the research are advised to contact the author for the final version of the publication, or visit the DOI to the publisher's website.

- The final author version and the galley proof are versions of the publication after peer review.

- The final published version features the final layout of the paper including the volume, issue and page numbers.

Link to publication

\footnotetext{
General rights rights.

- You may freely distribute the URL identifying the publication in the public portal. please follow below link for the End User Agreement:

www.umlib.nl/taverne-license

Take down policy

If you believe that this document breaches copyright please contact us at:

repository@maastrichtuniversity.nl

providing details and we will investigate your claim.
}

Copyright and moral rights for the publications made accessible in the public portal are retained by the authors and/or other copyright owners and it is a condition of accessing publications that users recognise and abide by the legal requirements associated with these

- Users may download and print one copy of any publication from the public portal for the purpose of private study or research.

- You may not further distribute the material or use it for any profit-making activity or commercial gain

If the publication is distributed under the terms of Article 25fa of the Dutch Copyright Act, indicated by the "Taverne" license above, 


\section{MIND THE BODY}

Omtrent omgang met lichamelijke klachten en ziekten bij chronische patiënten in een sociaal psychiatrische praktijk 



\section{MIND THE BODY}

Omtrent omgang met lichamelijke klachten en ziekten bij chronische patiënten in een sociaal psychiatrische praktijk

Proefschrift

ter verkrijging van de graad van doctor

aan de Rijksuniversiteit Limburg te Maastricht, op gezag van de Rector Magnificus, Prof. Dr. F.I.M. Bonke, volgens het besluit van het College van Dekanen, in het openbaar te verdedigen op vrijdag, 8 december 1989 om 16.00 uur

door

Adriaan Honig

geboren op 11 oktober 1952 te Utrecht 


\section{Promotores:}

Prof. Dr. H. Philipsen

Prof. Dr. M.A.J. Romme

\section{Beoordelingscommissie:}

Prof. Dr. J.J.C.B. Bremer, voorzitter

Prof. Dr. J.A. Flendrig

Prof. Dr. C.A.L. Hoogduin

Prof. Dr. W. van Tilburg

Prof. Dr. F.H.M. Verhey

\section{CIP-GEGEVENS KONINKLIJKE BIBLIOTHEEK, DEN HAAG}

Honig, Adriaan

Mind the body: omtrent omgang met lichameijike klachten

en ziekten bij chronische patienten in een sociaal

psychiatrische praktijk / Adriaan Honig; ; [ill. wan de

auteur] - Maastricht : Datawyse. - I11.

Proefschrift Maastricht. - Met lit. opg. - Met

samenvatting in het Engels.

ISBN 90-5291-010-3

SISO 606.6 UDC 616.89-052-07(043.3)

Trefw: chronische pationten ; sociale psychiatrie:

somatologic.

Productie: Datawyse Maastricht; druk: Krips Repro Meppel

Financiële ondersteuning bij de uitvoering van het onderzoek:

RIAGG Maastricht

Financiële ondersteuning bij de uitgave van de onderzoeksresultaten:

Duphar Nederland B.V.,

Sanofi Nederland, ICN Pharmaceuticals Holland B.V., Sandoz B.V.,

Lundbeck B.V., RIAGG Maastricht. 


\section{INHOUDSOPGA VE}

pag.

Hoofdstuk 1: Inleiding

1.1

1.2

1.3

1.3 .1

1.4

1.4 .1

1.4 .2

1.4 .3

1.4 .3 .1

1.4.3.2

1.5

1.6

1.6.1

1.6 .2

1.7

1.8

Hoofdstuk 2: Probleemanalyse als onderdeel van de omgang met chronische psychiatrische patiënten in de ambulante geestelijke gezondheidszorg.

Problem analysis: an instrument in the rehabilitation of chronic psychiatric patients in the community

(The International Journal of Social Psychiatry, 33, 4, 303-311, 1987)

Hoofdstuk 3: Miskend of ontkend probleemgebied. Somatische aandoeningen bij ambulante chronische psychiatrische patiënten.

Undervalued or denied problem area. Somatic dysfunctioning of chronic psychiatric patients living in the community (Tijdschrift voor Psychiatrie, 28, 10,676-686, 1986)

Hoofdstuk 4: Het lichamelijk welbevinden van ambulante chronische psychiatrische patiënten. Een onderzoeksprotocol. Physical illness in the chronic community psychiarric patient: a critical review

(Tijdschrift voor Sociale Gezondheidszorg, 66, 181-184, 1988)

Hoofdstuk 5: Lichamelijke ziekten in een ambulante praktijk voor chronische psychiatrische patiënten: behandelingsconsequenties.

Physical illness in chronic psychiatric patients from a community psychiatric unit: the implications for daily practice

(British Journal of Psychiatry, 155, 58 - 64, 1989) 
pag.

Hoofdstuk 6: Herkenning van lichamelijke xiekten bij ambulante chronische psychiatrische patienten met behulp van een klachtenlijst.

Detecting physical disease by questionnaire in chronic community psychiatric patients

(Hospital and Community Psychiatry, in press)

Hoofdstuk 7: De waarde van overeenstemming in het herkennen van lichamelijke zilekten bij ambulante chronische psychiatrische patiënten.

The influence of consensus on the assessment of physical disease in chronic community psychiatric patients

(Psychotherapy and Psychosomatics, in press)

\section{Hoofdstuk 8: Uitleiding}

8.1 Ordening in de chaos.

8.2 Het lichamelijk welbevinden van de ambulante

8.2.1 Epidemiologische gegevens over frequentie, aard en 103

8.3 Miskenning van somatiek.

8.3.1 Miskenning bevordlerende factoren.

8.4 Somatische screeningsinstrumenten.

8.4.1 Een klachtenlijst als middel om lichamelijke ziekten

8.4.2 Overeenstemming als middel om lichamelijke ziekten 114

8.5 Samenhang tussen lichamelijke en andere probleemvelden. $\quad 114$

8.6 Gevolgen voor de dagelijkse sociaal psychiatrische praktijk.

8.7 Bijlagen

Hoofdstuk 9: Algemene conclusies en aanbevelingen.

General conclusions and implications.

Samenvatting.

Summary.

Referenties.

Dankwoord.

Curriculum vitae. 


\section{INLEIDING}

Een proefschrift kan haast niet beginnen zonder dat woorden of casuistiek van een beroemdheid uit het verleden worden aangehaald om het betoog aan te vangen en overtuigingskracht te geven. Hippokrates, Ilich of Freud doen het altijd goed.

Het ligt niet alleen aan mijn aard om deze trend niet te volgen. Vaak ook worden citaten of beroemde casusbeschrijvingen uit hun verband gehaald of een onbedoelde nadruk gegeven (Jansen en Merkelbach, 1988) en gebruikt voor een doel waarvoor zij oorspronkelijk niet waren geschreven. Het feit dat geciteerde auteurs geen weerwoord meer kunnen geven vormt dan slechts een schrale troost.

Ik zou dit betoog dan ook liever beginnen met casuïstiek over het onderwerp van dit betoog, de hulpverlening aan de ambulante chronische psychiatrische patiënt. Aan de hand van een ziektegeschiedenis zou ik de aanleiding en het doel van mijn dissertatie willen verhelderen.

\section{1 "Mind the body": omtrent omgang met lichamelijke klachten en ziekten bij chronische patiënten in een sociaal psychiatrische praktijk}

Ongeveer vier jaar geleden nam ik, als psychiater van een sociaal psychiatrische dienst, de behandeling over van een 27 -jarige alleenwonende, ongehuwde jonge vrouw afkomstig uit een middenstandsmilieu. $\mathrm{Zij}$ was bekend met schizofrenie en hoorde vanaf har $17 \mathrm{e}$ jaar stemmen die haar soms afleiding gaven in haar in toenemende mate lege en geisoleerd bestaan. Bij tijd en wijle waren deze stemmen ook een marteling voor haar. Bij het eerste contact, een huisbezoek, trof ik haar in deze laatste toestand aan. Ze woonde in een kale kamer met kapot geslagen meubelen, zag er slecht verzorgd uit en converseerde hardop met mensen die ik niet waar kon nemen. Zij lag op de sofa naar zij vertelde omdat zij last van rugpijn had. Voorts vertelde zij me niet te hebben uitgenodigd en geen prijs op mijn gezelschap te stellen. Om dit kracht biji te zetten vloog even later met een welgemikte worp een lege fles in mijn richting.

De toestand van patiënte werd onhoudbaar en enige maanden later werd zij door middel van een rechterlijke machtiging opgenomen. Ook klinisch bleek zij weinig gemotiveerd om hulp te aanvaarden. $\mathrm{Zij}$ weigerde mee te doen aan het afdelingsgebeuren of de haar 
ananeboden bezigheden. In de derde maand van haar opname kreeg zij recidief rugklachten en blek ex bij lichamelijk onderzoek aanleiding haar nader somatisch te laten onderzoken middels een opname in een algemeen ziekenhuis. Zij bleek een niersteen ter grootte van een duvenei te hebben en ten gevolge van de hierdoor frequent opgetreden ontstekingen cen onherstelbax beschadigde mier. Deze nier werd operatief verwijderd. Na de operatie werd patiente communicatiever en coöperatiever; het haar aangeboden programma bleek zij beter te kunnen volgen en zij participeerde meer aan her afdelingsgebeuren. Haar wanen en hallucinaties bleven onveranderd bestaan.

\section{Wat leerde mij de ziektegeschiedenis?}

Allereerst de veelheid van de problemen van de patiènte waarmee ik als hulpverlener in de ambulante geestelijke gezondheidszorg werd, en nog steeds word, geconfronteerd. Patiënte was psychisch ziek, eenzaam, geisoleerd, had lichamelijke klachten en hield hulpverlening op een afstand.

De lichamelijke klachten van patiënte had ik destijds wel waargenomen maar deze werden overschaduwd door een veelheid aan andersoortige problemen die mijn direkte aandacht vroegen. Hierdoor gaf ik onvoldoende aandacht aan haar lichamelijke klachten. Ik had daardoor een lichamelijke ziekte gemist; hoe had ik dit kunnen voorkomen, patiëmte was immers niet tot medewerking bereid. Hoe kon ik miskenning van somatiek in de toekomst voorkomen? Hoe vaak is er sprake van lichamelijke ziekte bij deze groep patiënten?

Ook de wraag of opname van patiënte voorkomen had kumnen worden als de lichamelijke ziekte eerder was onderkend, hield mij sterk bezig."

Was er een samenhang tussen haar lichamelijke ziekte en psychiatrische ziektebeeld? Een oorzakelijk verband leek gezien het verloop van de ziektegeschiedenis onwaarschijnlijk, maar hoe zag die samenhang er dan uit?

Met enige weemoed dacht ik an mijn opleidingstijd terug in de meer klassieke ziekenhuis- en inrichtingspsychiatrie waar een aantal probleemvelden van een patiënt tijdelijk titgeschakeld of op een afstand gezet konden worden d.m.v. een opname. De patiënt wordt dan immers uit zijn leefmilieu in een instituut geplaatst. Ik besefte opnieuw dat de ambulante psychiater zijn werk vaak onder minder ideale omstandigheden moet verrichten dan zijn vakbroeders in de kliniek. Ambulant zijn er bijvoorbeeld minder mogelijkheden om een patiënt over langere tijd te observeren; aanvullend onderzoek kan alleen plaatsvinden via derden of via ingewikkelde verwijzingsprocedures. Hetzelfde geldt voor routirive somatische screeningen in het geval dat de betreffende behandelaar geen medicus is. Ook zijn er minder mogelijkheden tot intercollegiaal consulteren dan in het ziekenhuis. 
Waar moet je ambulant nu beginnen in de hulpveriening aan deze patienten? Hoe kan worden voorkomen dat belangrijke informatie over het hoofd wordt gezien? Bovendien ontgaat ons niet zelden de relevantie van de vragen warar de patienten zelf mee komen, alls ze al tot een hulpvraag kunnen komen (Rotteveel e.a., 1988). De routinematige ziekenhuis- en inrichtingspsychiatrische strategieën kunnen in de ambulante praktijk niet worden uitgevoerd, aangezien zij zijn ontworpen voor een door de hulpverlener beheersbare en voor diagnostisering en behandeling speciaal toegeruste ongeving (het ziekenhuis).

Deze ziektegeschiedenis bracht mij ertoe om vanuit de reflecties die ik hier boven heb geschetst vijf onderzoeksvragen te ontwikkelen, die uiteindelijk de basis van dit promotieonderzoek vommen, namelijk:

1. Hoe kan lichamelijk onwelbevinden worden onderkend wit de vele problemen wan de ambulante chronische psychiatrische patiënt?

2. Wat is de aard, ernst en omvang van lichamelijke klachten en ziekten bij ambulante chronische psychiatrische patienten?

3. Hoe vaak wordt bij de ambulante chronische psychiatrische patiënt lichamelije ziekte miskend?

4. Is het mogelijk om een eenvoudig hulpinstrument te ontwikkelen om lichamelijke ziekten op te sporen bij ambulante chronische psychiatrische patienten; een instrument dat gehanteerd kan worden door ook niet strikt medische disciplines?

5. War is de samenhang tussen lichamelijk onwelbevinden en onwelbevinden op andere probleemgebieden wan de ambulante chronische psychiatrische patiënt?

De doelstelling van dit promotieonderzoek die door middel van deze vijf vragen wordt beantwoord is: de ontwikkeling van een omgang met lichamelijke klachten en ziekten van de chronische psychiatrische patiënt in de ambulante sociaal psychiatrische praktijk.

Deze dissertatie is in grote lijnen opgebouwd uit twee onderdelen:

allereerst een inleiding en conclusie (respectievelijk hoofdstuk 1 en 8 ) en voorts een zestal artikelen (hoofdstuk $2 \mathrm{t} / \mathrm{m} 7$ ). 
In de inleiding worden de bovenstande vijf onderzoeksvragen verder witgewerkt.

Deze onderzoekswragen fungeren dus als rode draad voor mijn betoog. In de conclusie (hoofdstuk 8) zal ik de onderzoekswragen beantwoorden met behulp van uit onderzoek verktegen gegewens. Vervolgens zal ik enige aarbevelingen doen aan hulpwerleners in de ambulante geestelijke gezondheidszorg ter verbetering van de omgang met lichamelijke klachten en ziekten van chronische psychiatrische patienten.

De in dit proefschrift opgenomen artikelen zijn voortgekomen uit deze onderzoekslijn. In zowel de inleiding als conclusie zal dan ook regelmatig aan deze genoemde artikelen worden gerefereerd.

Allereerst zullen de vijf genoemde onderzoeksvragen in de nu volgende paragrafen worden uitgewerkt.

\subsection{Ordening in de chaos}

Hoe kan licharmelijk onwelbevinden worden onderkend uit de vele problemen van de ambulante chronische psychiatrische patiënt?

Voor de dagelijkse ambulante psychiatrische praktijk lijkt het meer klassiek medisch georiënteerde model zoals dat wordt gehanteerd in de ziekenhuis- en inrichtingspsychiatrie te restrictief. Met het klassieke medische model bedoel ik het klinische medische model zoals aangegeven door Siegler en Osmond (1974). Dit klassieke medische model heeft een drietal specifieke kenmerken, namelijk:

- De patiènt stakt centraal en wordt opgevat als drager of draagster van symptomen; de patient heeft daarbij specifieke rechten en plichten;

- het zoeken naar een oorzatak of een aantal oorzaken (etiologie), die in lineair causaal (oorzaak-gevolg) of hooguit wederkerig verband staat of staan tot de klachten;

- Dualisme of uitsluiting: een klacht heeft een lichamelijke en/of psychosociale oorzaak.

Een psychologische of psychosociale oorzaak wordt aangenomen aanwezig te zijn bij afwezigheid van een lichamelijke dysfunctie die de klachten voldoende kan werklaren.

Elk model brengt een ordening aan in wat wij waarnemen; elke ordening gaat gepaard met verlies van informatie. Welnu, het verlies aan informatie van het klassieke medische model is voor de dagelijkse ambulante psychiatrie te groot geworden om nog produktief te kunnen zijn. Adler (1984) gaf dit als volgt aan: "Considering the chronic patient as an 
individual adjusted within his life space rather than as a bearer of treatment outcomes has considerable heuristic potential".

Romme e.a. (1981) hadden in het boek "Wat is sociale psychiatrie" reeds een voorstel gedaan om tot een andere meer systematische ordening binnen de ambulante psychiatrische hulpverlening te komen (paragraaf 5.5, p. 83-87 en paragraaf 8.4 .3 , p. 126-132). Hierin gaan zij uit van het systeemmodel als basis om de problemen van ambulante chronische psychiatrische patiènten te ordenen, om na ordening te komen tot een weloverwogen behandelingsplan. Voor dit betoog is het van belang dat ik deze theorie nader toelicht.

De betreffende systeentheorie ontworpen door Von Bertalanffy (1950), moet opgewat worden als een ordenend prinicpe en niet als een verklarend principe. In deze laatste betekenis wordt het wel als een synoniem opgevat voor theorieen waarop gezinstherapie is gebaseerd. Het hier bedoelde systeem beperkt zich niet tot het gezin, maar heeft een veel bredere betekenis. Zoals het klassieke medische model de patiënt als drager van symptomen centraal stelt, zo staat in de systeemtheorie het begrip "open systeem" centraal. Kenmerk van dergelijke open systemen is dat zij het vermogen bezitten zich te kunnen handhaven d.m.v. een voortdurende wisselwerking van de afzonderlijke elementen (ook wel subsystemen genoemd) onderling en van elk systeem met de omgeving, waardoor een dynamisch evenwicht ontstaat. Aan een open systeem kan met andere woorden altijd informatie toegevoegd worden en is aan veranderingen onderhevig. Een patiënt kan als zo'n open systeem worden opgevat, maar is op zijn of haar beurt weer een subsysteem van een groter systeem. Elk systeem is opgebouwd uit een aantal subsystemen of elementen die hierarchisch zijn geordend. Elk element afzonderlijk is opnieuw op te vatten als een open systeem. Engel (1980) populariseerde deze theorie in de zeventiger jaren en beschreef de patiënt als een onderdeel van zo'n open hierarchisch systeem, beginnend bij atomen en molecullen, via orgaansystemen, zenuwstelsel, beleven en gedrag, tot gezin, gemeenschap en uiteindelijk, overigens zeer aktueel, de biosfeer.

Dit model, dat in Nederland goed beschreven is door Milders en van Tilburg (1988), biedt een aantal voordelen:

Allereerst geeft het een samenhang tussen verschillende onderdelen van complexe problematiek, waarvan die van de ambulante chronische psychiatrische patient een voorbeeld is.

Ten tweede kan dit model grensoverschrijdend werken voor wat de professionele achtergrond van verschillende hulpverleners betreft.

Daarmee is dit model goed toepasbaar binnen een multidisciplinair werkend team, zoals dat van een Sociaal Psychiatrische Dienst. 
On de systemtheorie toepastar te maken voor de ambulante geestelijke gezondheidszorg werd binnen de onderzoekslijn "de chronische patient", een samenwerkingswerband tussen de vakgroep Sociale Psychiatrie en de Sociaal Psychatrische Dienst van de RIAGG (Regionale Instelling Ambulante Geestelijke Gezondheidszorg) te Maastricht, een open systeem ontworpen bestaande uit vier elementen; deze elementen worden in dit onderzoek probleengebieden of nivo's genoemd (zie figuur 1). Door middel van praktijk georienteerd onderzoek werd elk nivo binnen de onderzoekslijn "de chronische patiënt" verder uitgewerkt (Romme e.a., 1988).

\section{Deze vier nivo's zijn:}

- orgaannivo, met o.a. lichamelijke klachten en ziekten (nivo 1)

- nivo van het individu, met o.a. individueel psychologische problemen (nivo 2)

- nivo van de kleine groep, met o.a. netwerkanalyse van de direkt betrokkenen; de onder. linge relaties tussen de betrokkenen uit het directe netwerk van de patiënt, alsook hun funkties voor de patiënt (nivo 3)

- mivo van de organisatie van groepen, met o.a. arbeidswerleden, omgang met instanties, deelname aan maatschappelijk verkeer (nivo 4).

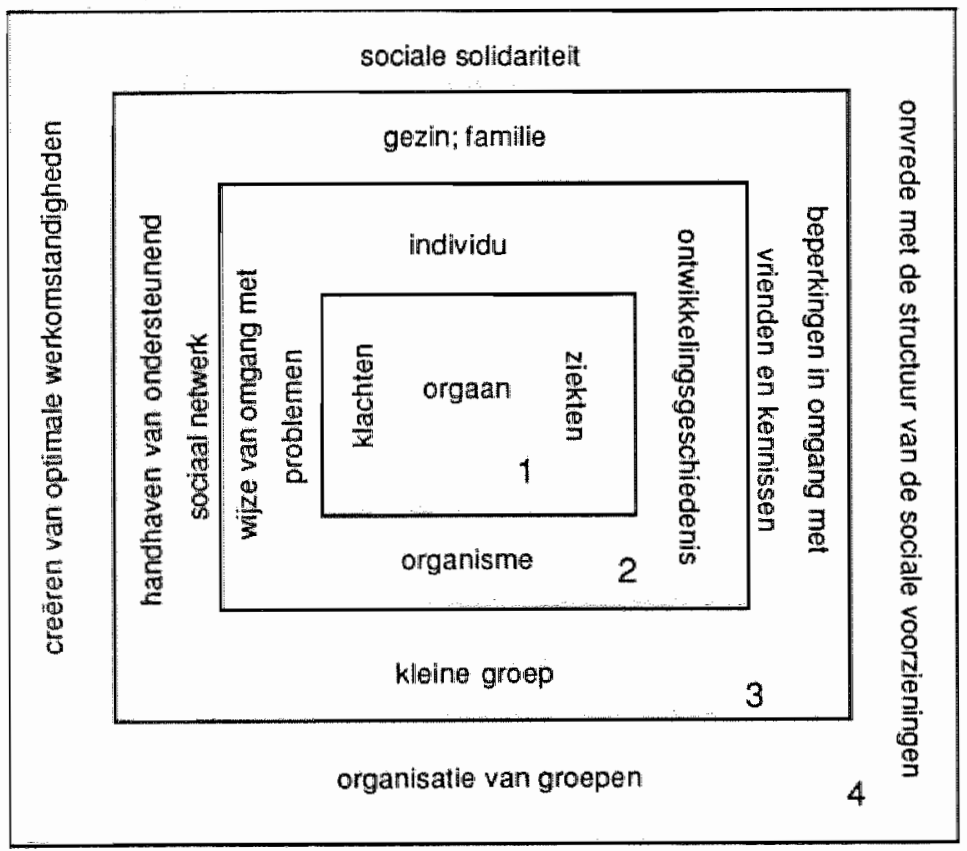

Figuur 1 Systemische probleeminventarisatie (naar Romme e.a., 1981) 
Hiemee was een nieuw kader geschapen warbinmen problemen in de ambullante geestelijke gezondheidszorg aan chronische patienten geordend konden worden. Met eerste wat daarbij nodig was en ontbrak was een praktische uitwerking van dit aangepaste model Met andere woorden, een hulpinstrument dat ordent, behandelingsgeorienteerd is en hanteerbaar voor alle hulpverleners, ongeacht discipline, van een sochal Psychiatrische Dienst.

In hoofdstuk 2 genaamd: "Probleemanalyse als onderdeel van de ongang met chronische psychiatrische patiènten in de ambulante geestelijke gezondheidszorg (Honig e.a., 1987) wordt dit hulpinstrument, de probleemanalyse genaamd, beschreven als middel om ordening in de chaos van en rond de patient te verkrijgen. Ook lichamelijke klachten en afwijkingen kunnen d.m.v. deze semigestructureerde wijze van informatieverzameling onderkend worden. Daamee is een antwoord geformuleerd op de eerste onderzoeksvraag.

Gegeven deze ordening en het op basis daarvan ontworpen hulpinstrument, de probleemanalyse, ontstond bij de onderzoekers die participeerden in de ontwikkeling van deze probleemanalyse de behoefte om elk afzonderlijk geidentificeerde probleemgebied nader te beschouwen. De daaruit voortwloeiende onderzoeken en publikaties zijn onder andere samengebracht in "Research to practice in community psychiary" (Romme e.a.; 1988).

Het gemeenschappelijk doel was, door middel van een systematische inventarisatie de structurele veranderingen op elk nivo van functioneren te kumnen onderkennen, om wervolgens strategieën te ontwikkelen die deze tekorten of gebreken verminderen. Hierdoor kan een nieuw en mogelijk stabieler evenwicht ontstaan tussen de nivo's onderling.

Mijn keuze viel daarbij op het onderzoeken van het eerste nivo: het lichamelijk welbevinden van de ambulante chronische psychiatrische patiënt.

\subsection{Het lichamelijk welbevinden van de ambulante chronische psychiatrische patiënt}

Wat is de aard, ernst en omvang van lichamelijke klachten en ziekten bij ambulante chronische psychiarrische patiënten? 
Terugkerend nar de eercler genoemde ziektegeschtedenis wordt duidelik dat deze patiente lichamelike klachten heeft. $U$ zult zeggen dat ik deze gevalsbeschnjuing heb gekozen om wille van mign betoog. Naturilijk heeft U gelijk maar, zoals uit de onderzoeksresultaten zal blijken, hebben 9 van de 10 ambulante chronische psychiamische patiënten lichamelijke klachten. Wat lichamelijke klachten betrefi womt deze ziektegeschiedenis dus zeker geen uilzondering matr eerder regel.

\subsubsection{Epidemiologisehe gegevens over frequentie, aard en ernst van lichamelijke ziekten}

De eerste stap in het beantwoorden van de in deze paragraaf gestelde vraag is het natrekken van literatuur op dit gebied.

Epidemiologische studies over vóórkomen van lichamelijke ziekte is ruim voorhanden voor wat opgenomen acute en chronische psychiatrische patiënten betreft. Onderzoek toont een duidelijke relatie aan tussen lichamelijke en psychiatrische ziekten (Roessler en Greenfield, 1961; Lipowski, 1967; Eastwood en Trevelyan, 1972). Rooymans (1983) heeft een overzicht gemaakt van studies over lichamelijke ziekten bij psychiatrische patiënten. Die studies betroffen met name klinische en poliklinische populaties.

Het aantal publikaties over somatische stoomissen bij de ambulante chronische patiënt was destijds (1985) te tellen op de vingers van én hand. De beschikbare gegevens gaven wel als trend aan dat lichamelijke ziekten ook bij ambulante chronische psychiatrische patiënten veelvuldig worden geconstateerd (Barnes e.a., 1983; Beresford e.a. 1985). Het vó́rkomen van lichamelijke ziekten bij psychiatrische patiënten ligt tussen de 30 en $60 \%$ zowel klinisch als ambulant. Gemiddeld de helft van de geconstateerde lichamelijke ziekten is aan de verwijzer van de patiènt bekend. Van de gevonden percentages lichamelijke ziekten wordt $40 \%$ beschouwd als oorzakelijk voor het psychiatrische ziektebeeld of dit verergerend (Summers, 1981; Rooymans, 1983; Ananth, 1984). De medische problemen die uiteindelijk atantoonbaar zijn bij psychiatrische patiënten, beslaan het gehele medische spectrum (Rooymans, 1.983; Ananth, 1984) en hebben vaak een lange "incubatietijd" (Hoffman en Koran, 1984). Wat de ernst van de somatische aandoeningen betreft kan gesteld worden dat psychiatrische patiênten gemiddeld op jongere leeftijd sterven dan niet-patiënten, ook na correctie voor suicide en ongevallen (Babigian en Odoroff, 1969; Shinozaki, 1976; Giel e.a., 1978; Sims, 1987).

Concluderend kan uit de literatuurgegevens opgemerkt worden dat lichamelijke ziektes vaak voorkomen, relatief vaak als oorzaak van het psychiatrisch ziektebeeld worden 
gezien en leiden tot een owersterfte van de psychiatrische patient in vergeliking mer de algehelle bevolking.

De bovengenoemde bevindingen en overwegingen gaven aanleiding om de tweede stap ta wagen: de opzet en uitvoering van eem pilotstudie met als doel een eerste indruk te krijgen over de frequentie en ernst van somatische klachten en aandoeningen van ambulante chronische psychiatrische patienten binnen onze eigen Social Psychiatrische Dienst.

De gegevens verkregen uit deze pilotstudie kwamen overeen met de genoemde literatuur gegevens, voor wat betreft frequentie van vó́rkomen van ziekten. Door de wijze warop deze pilotstudie was opgezet kon geen antwoord worden gegeven op de vrag naar oorzakelijkheid van somatische ziekten voor het psychiatrische toestandsbeeld. Het hoge percentage lichamelijke klachten van de patiënten was een nieuwe bevinding.

Deze eerste twee stappen in het onderzoek van het lichamelijk welbevinden van ambulante chronische psychiatrische patiënten worden uitvoerig beschreven in hoofdstuk 3 : "Miskend of ontkend probleemgebied. Somatische aandoeningen bij ambulante chronische psychiatrische patiënten" (Honig e.a., 1986).

\subsection{Miskenning van somatiek}

Hoe vaak wordt bij de ambulante chronische psychiarrische patiënt lichamelijke ziekte miskend?

Het niet onderkennen wan lichamelijke ziekten door hulpverleners in de geestelijke gezondheidszorg wordt genoemd als een belangrijk kenmerk van dit probleemgebied. (Rooymans, 1983; Ananth, 1984).

Deze miskenning is niet alleen een probleem in psychiatrische settingen, mar ook in andere ambulante gezondheidszorgsectoren, zoals de huisartspraktijk (Eastwood en Trevelyan, 1972). Ook in de kliniek worden lichamelijke ziekten onjuist beoordeeld. Ui: een groot opgezet onderzoek in 1980 onder leiding van de Britse chirurg De Dombal, in verscheidene landen gedurende een periode van tien jaar waarbij meer dan 10.000 gevallen van acute buikpijn werden bestudeerd, bleek dat in praktisch alle ziekenhuizen ongeveer de helft van het aantal gepresenteerde gevallen in eerste instantie verkeerd werd beoordeeld. Mede hierdoor kon het gebeuren dat meer dan een kwart, soms meer dan de helft, van het aantal acute appendicitiden reeds geperforeerd was of een abces had gevormd op het moment van opereren. Het aantal negatieve laparotomieën varieerde 
tussen de $20 \%$ en $80 \%$. Eén op de drie gevallen wan mathiniteit als oorzaak van de buikklachten werd niet als zodanig herkend en zelfs naar hüs gestuurd (Krebber, 1988). Miskenning van lichamelijke ziekte komt frequenu voor en is blijkbar nuet beperkt tot psychiaters of huisartsen in de ambulante praktijk, maar ook in de kliniek. Toch lijkt miskenning niet alleen een zuiver medisch diagnositisch probleem. Drie andersoortige problemen kunnen hierbij worden onderscheiden. Definiëringsproblemen, interactionele problemen tussen patiènt en hulpverlener en voorziening gebonden factoren kunnen een rol spelen in het niet herkennen van ziekten door de hulpwerlener. Deze drie factoren zullen nu elk apart besproken worden.

\subsubsection{Definiëringsproblematiek}

Wat de ene hulpverlener een lichamelijke ziekte noemt hoeft niet overeen te komen met de definiêrring van een andere hulpverlener; dit betekent nog niet dat één van de twee hulpverleners een ziekte miskent in de betekenis van over het hoofd zien. Dit definitie probleem is in de literatuur terug te vinden doch slechts zelden opgelost. Sommige auteurs gaan zo ver om afwijkende serum laboratoriumwarden of een verdikking aan de binnenzijde van de schedel in het gebied van het voorhoofd (hyperostosis interna frontalis) als ziekte aan te duiden (Hall e.a., 1980). Een dergelijke wijze van diagnostiseren zal zeker tot hoge percentages miskenning van "ziekte" aanleiding geven. In de psychiatrische literatuur wordt zelden een definitie gehanteerd of criteria voor lichamelijke ziekte gegeven. Dientengevolge is vaak de klinische betekenis van de gevonden somatische afwijkingen onduidelijk. Een eenduidige definiëring van het begrip lichamelijke ziekte is in epidemiologische studies op dit gebied onontbeerlijk, zeker als men onderzoeksresultaten van verschillende studies wil vergelijken. In het onderhavige onderzoek wordt een pragmatische definiering aangehouden zoals werd gebruikt door Eastwood en Trevelyan (1972) en Hoogduin e.a. (1985); van lichamelijke ziekte is in het onderhavige onderzoek sprake in geval van klachten, symptomen of bevindingen die een medische behandeling behoeven of warbij nader medisch onderzoek is geindiceerd ter diagnostisering c.q. uitsluiting van een vermoede ziekte. Hiermee worden dus alleen die lichamelijke stoornissen als lichamelijke ziekte geselecteerd die tot het aanbieden van somatische hulp aanleiding geven. Een ziekte werd voorzien van de aanduiding "niet zeker" wanneer aan de genoemde definiering van ziekte werd voldaan, maar de vermoede ziekte nog nadere diagnostiek behoefde. 
Als reden om psychiatrische patienten niet lichamelik te onderzoeken en damarmee miskenning van somatiek in de hand te werken, worden vooral casuistisch aangehnald in de literatuur: "malodorous", "dirty", "may not cooperate" (Kampmeier, 1977, Hoffman en Koran, 1984), "unattractive and poor" (Adler, 1972). Afgenomen cognitieve functies en psychische retardatie wordlen vak genoemd als een aanzienlijke hinderpaal in het opnemen van een somatische anamnese (Ramsay e.a., 1982a; Ramsay en Engelsmann, 1983), vooral bij langdurende psychiatrische problematiek (Ramsay e.n., 1982b).

In hoeverre deze meningen berusten op vooroordelen of realiteit dient mader te worden onderzocht. Hiertoe kunnen de gedragingen tijdens een lichamelijke screening van onze te onderzoeken patiënten populatie worden geobjectiveerd. Vervolgens kunnen die uitkomsten worden vergeleken met die van een naar leeftijd en geslacht gelijksoortige niet psychiatrische patiëntenpopulatie.

Ook dient geinwentariseerd te worden of ambulante chronische psychiatrische patienten gebruik maken van voor elke Nederlander toegankelijke medische le-lijns-voorzieningen. In welke mate bezoeken ambulamte chronische psychiatrische patienten hun huisarts en is de huisarts op de hoogte van hun lichamelijk (on)welbevinden? Immers, als zij zich nie! medisch laten onderzoeken, wat valt er dan nog te miskennen?

Gegevens hierover ontbreken wolledig en zijn niet alleen van belang om de omvang van het probleem van de miskenning aan te kunnen geven, maar belangrijker nog om de hulpverlening op dit gebied zo mogelijk te verbeteren.

De uitkomsten van beide in deze paragraaf opgeworpen onderzoeksvragen worden besproken in hoofdstuk 5: "Lichamelijke ziekten in een ambulante praktijk voor chronische psychiatrische patiënten: behandelingsconsequenties" (Honig e.a., 1989) alsook in paragraaf 8.4 .1 .

\subsubsection{De rol van ambulante gezondheidszorgvoorzieningen}

\subsubsection{De Sociaal Psychiatrische Dienst}

In tegenstelling tot de ziekenhuis- en inrichtingspsychiatrie zijn de voorzieningen voor somatische zorg in de ambulante geestelijke gezondheidszorg lacumair. Binnen de 
ambulante geesteljke gezondhetdszorginstellingen wordt vel gewerkt in multidisctplinair teamverband. Binmen dergeljke teams wordt ieder teamlid in principe in staat geacht een behandeling te kwmen witvoeren onder de witeindelike verantwoordelijkheid van een psychiater. Lichamelijk onderzoek vindt daarbij doorgaans alleen plaats op indicatie. Routine lichamelijk onderzoek is wel gebnilkeljjk in de intramurale setting. Alleen al de beperkte hoeveelheid beschikbare medische mankracht staat een dergelijk routine onderzoek in de ambulante sector in de weg. Vaak is het daarom aan de sociaal psychiatrische verpleegkundige, de algemeen maatschappelijk werkende of psycholoog wan een dergelijk team om de signalen op te vangen en door te geven die tot een indicatie voor verder lichamelijk onderzoek kunnen leiden.

Aanvullend onderzoek kan niet rechtstreeks door een ambulante psychiater worden verricht. Dit kan alleen via de huisarts wan de patiẻnt worden aangevraagd. De eigen onderzoeksmogellijkheden beperken zich tot de fysische diagnostiek met stethoscoop, reflexhamer, oogspiegel, speld en het wattenstaafje. Zowel voor de stap die leidt tot fysisch diagnostisch onderzoek alls die welke leidt tot aanvulend onderzoek dient dus vrijwel altijd een ander dan de behandelende geestellike gezondheidszorg hulpverlener te worden ingeschakeld. Deze gang van zaken geeft weinig stimulans om signalen wijzend op een lichamelijke dysfunctie, als die al opgevangen worden, adequaat te verwerken.

De geschetste praktijk van een Sociaal Psychiatrische Dienst t.a.v. lichamelijke ziekte was moeilijk te rijmen met de hoge percentages gevonden, causaal geduide, lichamelijke ziekten. Des te meer de wrijwel eenduidige conclusie van onderzoekers op dit gebied om bij psychiatrische patiënten frequent routine lichamelijk onderzoek, alsook aanvullend laboratoriumonderzoek te verrichten.

Op basis van somatische screeningsgegevens leek een routinematig uit te woeren lichamelijke keuring van onze algehele sociaal psychiatrische populatie een onmisbaar onderdeel te zijn van de door de ambulante geestelijke gezondheidszorg te bieden zorg.

Daarmee was zowel om redenen van onderzoek alls van patientenzorg voldoende aanleiding om tot een lichamelijke screening van onze chronische patièntenpopulatie te besluiten.

\subsubsection{De huisartsenpraktijk}

In Nederland zoekt ongeveer $75 \%$ van de bevolking minimaal énmaal per jaar contact met zijn huisarts; het aantal contacten met de huisarts per jaar voor de gemiddelde volwassen Nederlander is \pm 3.5 (Swinkels, 1988). Tachtig tot $90 \%$ van alle aan de 
Nederlandse gezondheidszorg aangeboden problemen, worden geheel binnen de huisartspraktijk afgehandeld (Knottnerus, 1988).

Gelden deze cijfers ook voor de chronische psychiatrische patient due onder behandeling is van de ambulante geestelijke gezondheidszorg? Dit is in het geheel niet onderzocht:

Het is de vraag of de zorg voor de lichamelijke gezondheid van de patient primair bij de huisarts of bij de Sociaal Psychiatrische Dienst ligt. Resocialisatie en reintegratie van de patiënt zou idealiter ook gepaard moeten gaan met een (her)gebruik van gezondheidszorg faciliteiten zoals de gemiddelde Nederlander dat pleegt te doen. Er zou dus zeker vanuit dit standpunt gezien een lans te breken zijn voor een rol wan de huisarts in de lichamelijke gezondheidszorg van de ambulante chronische psychiatrische patient. Dit is alleen mogelijk als bekend is of en in welke mate ambulante chronische psychiatrische patienten gebruik maken van hun huisarts. In een onderzoeksprotocol dient dan ook het aandeel van de huisarts in de algehele hulpverlening aan de patiënt geïnventariseerd te worden evenals de door de huisarts gediagnostiseerde ziekten.

De volgende stap was dan ook het opstellen van een onderzoeksprotocol, beschreven in hoofdstuk 4: "Het lichamelijk welbevinden van ambulante chronische psychiatrische patiënten, een onderzoeksprotocol" (Honig e.a., 1988).

De onderzoeksresultaten van het epidemiologische onderzoek voortvloeiend unt dit protocol zijn beschreven in hoofdstuk 5: "Lichamelijke ziekten in een ambulante praktijk voor chronische psychiatrische patiënten: behandelingsconsequenties", (Honig. e.a., 1989).

\subsection{Somatische screeningsinstrumenten}

Is het mogelijk om een eenvoudig hulpinstrwment te onwikkelen om lichamelike ziekten op te sporen bij ambulante chronische psychiatrische patiënten; een instrument dat gehanteerd kan worden door niet strikt medische disciplines?

Wanneer er over somatiek geschreven wordt gaat alle aandacht naar het inventariseren van lichamelijke ziekten; dit was ook het geval in de vorige paragraaf. Er is weinig aandacht voor de wijze waarop hulpverleners in de ambulante praktijk lichamelijke ziekten kunnen herkennen. Fysisch diagnostisch onderzoek en aanvullend laboratorium onderzoek is het enige instrumentarium dat aangereikt wordt door onderzoekers op dit gebied. Dit 
instrumentarium is weinig bruikbaar binnen een ambulante Sociaal Psychiatrische Dienst aangezien dit zou betekenen dat alle patienten onder behandeling van een Sociaal Psychiatrische Dienst regelmatig lichamelik onderzocht worden door een medicus van zo'n dienst. Juist medici zijn binnen dergelijke veelal multidisciplinair opgebouwde sociaal psychiatrische teams schaars. Zulke teams bestan nomaliter ait én psychiater, enige sociaal psychiatrische verpleegkundigen, een matschappelijk werker en soms een psycholoog. De tijdsinvestering die een regelmatige en routinematige lichamelijke screening zou vergen van de medicus wit zo'n team zou weinig ruimte meer laten voor andere specifieke activiteiten zoals psychiatrische diagnostisering, consultatie aan teamleden en het (doen) uitvoeren van psychiatrische behandelingen. Een dergelijke praktijkvoering laat daarom weinig praktische mogelijkheden voor het verichten van een routine lichamelijk onderzoek. Dientengevolge zou een toetsing waarbij in eerste instantie niet direct een medicus ingeschakeld hoeft te worden uitkomst bieden om toch enige vorm van regelmatige lichamelijke screening te kunnen verrichten. Twee mogelijke wijzen wan toetsing werden ontworpen en onderzocht.

Allereerst een eenvoudige vragenlijst in te vullen door de patiënt zelf. Deze lijst dient gevalideerd te zijn en eenvoudig te interpreteren. Een dergelijke klachtenlijst is gevonden in de Hopkins Symptom Checklist (Luteijn e.a., 1979).

In hoofdstuk 6: "Herkenning van lichamelijke ziekten bij ambulante chronische psychiatrische patiènten met behulp van een klachtenlijst" (Honig e.a., ter perse) worden de bevindingen van deze klachtenlijst als instrument in het onderkennen van lichamelijke ziekten beschreven.

Als tweede wijze van toetsing werd gekozen voor het onderzoeken van die factoren in de interactie tussen patiênt en hulpverlener die een juiste inschatting over de lichamelijke toestand van cen patiènt zouden kunnen bevorderen. Overeenstemming tussen patiênt en hulpverlener is zo"n factor (Kenney en Albright, 1987; de Ruiter en Cohen, 1987).

Het begrip overeenstemming dient enige nadere toelichting. Voor gedetailleerde informatie verwijs ik naar hoofdstuk 7: "De waarde van overeenstemming in het herkennen van lichamelijke ziekten bij ambulante chronische psychiatrische patiënten" (Honig e.a., ter perse). Binnen de geestelijke gezondheidszorg blijkt de mate van overeenstemming tussen patiènt en hulpverlener over de redenen voor hulpzoekgedrag een belangrijke maatstaf voor de mate van succes van het hulpwerleningsproces te zijn (Dormaar e.a., 1988). Analoog hieraan zou men kunnen veronderstellen dat gebrek aan overeenstemming kan leiden tot onvoldoende aandacht voor en daaruit voortvloeiend miskenning van somatiek. 
Een drietal wormen van overeenstemming, voor wat betreft lichamelijk welbevinden, tussen patiënt en hulpverlener kumen worden gemeten $\mathrm{nl}$ :

a. subjectieve overeenstemming; de mate watrin patient en hulpverlener van mening zijn dat ze het eens zijn met elkaar;

b. overeenstemming naar wederzijds pereeptie: de mate waarin patient en hulpverlener cen correcte inschatting maken van de mening van de ander met betrekking tot de somatiek en ongang daamme;

c. inhoudelijke overeensternming: de mate waarin patiènt en hulpverlener het eens zijn met betrekking tot de inhoudelijke omschrijving van de somatische problemen.

Deze eerste twee vormen van overeenstemming zijn te bepalen d.m.v. een vragenlijist, bestaande uit 20 wragen, die afzonderlijk door de patiënt en hulpverlener worden ingevuld (figuur $2 \mathrm{a}$ en $2 \mathrm{~b}$ ).

De derde vorm vereist een dermate hoog vermogen om abstract te kunnen denken dat hiervan voor onze sociaal psychiatrische populatie werd afgezien.

Figuur 2 a geeft een voorbeeld van een vraag zoals die d.m.v. een vragenlijst aan de patiënt wordt voorgelegd.

Figuur 2a

\begin{tabular}{|c|c|c|}
\hline Stelling & Mijn mening & $\begin{array}{l}\text { Hoe denkt U dat Uw hulp- } \\
\text { verlener hierop over U } \\
\text { zall antwoorden? }\end{array}$ \\
\hline Ik ben lichamelijk ziek & $\begin{array}{lllll}1 & 2 & 3 & 4 & 5\end{array}$ & $\begin{array}{lllll}1 & 2 & 3 & 4 & 5\end{array}$ \\
\hline
\end{tabular}

Figuur $2 b$ is een spiegelvraag die aan de hulpverlener wordt gesteld 
Figuar $2 b$

\begin{tabular}{|l|l|l|}
\hline Stelling & Mijn menimg & $\begin{array}{l}\text { Wat denkt U dat Uw } \\
\text { patiènt hierop zal ant- } \\
\text { woorden? }\end{array}$ \\
\hline $\begin{array}{l}\text { Deze patiènt is } \\
\text { lichamelijk ziek }\end{array}$ & 12 & \begin{tabular}{l}
1 \\
\hline
\end{tabular}
\end{tabular}

\subsection{Samenhang tussen lïchaam en geest}

Wat is de samenhang tussen lichamelijk welbevinden en anwelbevinden op andere probleemgebieden van de ambulante chronische psychiatrische patiënt?

In een literatuuroverzicht geeft Rooymans (1983) grofweg aan dat de helft van de psychiatrische patiënten een lichamelijke ziekte heeft, waarvan weer de helft in oorzakelijke relatie staat tot het psychiatrische ziektebeeld. Hall e.a. (1978) en Koranyi (1979) komen uit op ongeveer $10 \%$ van de psychiatrische patiënten met een duidelijk causaal organisch lijden.

De inleidende ziektegeschiedenis laat zien dat bij patiènte een ernstig nierlijden is miskend. Somatische behandeling van deze ziekte gaf aanleiding tot een verbetering van patiêntes subjectief lichamelijk welbewinden. Zij was beter in statat om contact te leggen en deel te nemen aan afdelingsactiviteiten. Het psychopathologisch beeld bleef echter onverminderd bestatan.

Duidelijk is dat er hier geen sprake is van een oorzakelijk of "specifiek" verband (Rooymans, 1974). Maar hoe kan de relatie ussen lichaam en geest dan wel worden beschreven? Is er hier sprake van twee afzonderlijke problemen (lichamelijke en psychologische) of is er wel degelijk sprake van een verband, door Rooymans betiteld als "typisch". Hij geeft hiermee aan dat er wel een zekere mate van correlatie is tussen het lichamelijk en het geestelijk dysfunctioneren maar dat deze relatie niet in alle gevallen opgaat. Dit mag dan een mooi empirisch wetenschappelijk onderscheid zijn, maar het geeft mij nog steeds geen inzicht in de daadwerkelijke relatie tussen lichaam en geest.

In de volgende paragrafen wordt deze relatie nader witgewerkt. 


\subsubsection{Het medische model}

De laatste tien jaar wordt in de literatuur het gebruik van het dualistische medische model benadrukt, zowel in de acute psychiatrie als in de psychiatrie zoals die wordt bedreven im een algemeen ziekenhuis (Sandifer, 1977; McIntyre en Romano, 1977; Guze; 1978; Adler, 1981; Hoffman en Koran, 1984). In dit model staat de patiènt met zijn klachten en symptomen centraal. Deze klachten en symptomen worden geordend in ziektebeelden of syndromen en vervolgens in verband gebracht met een lichamelijke en/of psychosociale oorzaak.

Wanneer de specifieke oorzaak is vastgesteld volgt een specifieke behandeling (antidotum) van de ziekte. Met andere woorden, de samenhang tussen klachten en afwijkende bevindingen an de ene kant en ziekteverwekker aan de andere kant wordt gekenmerkt door oorzakelijkheid; A leidt tot $\mathrm{B}(\mathrm{A} \rightarrow \mathrm{B})$ of door wederkerigheid $(\mathrm{A} \rightleftarrows \mathrm{B})$, Dit model is eenvoudig en overzichtelijk maar is niet toepasbaar in elke situatie.

Laat ik U twee voorbeellen ter verduidelijking geven.

Een 42-jarige werknemer van een middelgroot bedrijf wordt verwezen naar een psychiatrische dienst wegens een voor de eerste maal opgetreden depressiviteit. Zijn anamnese en lichamelijk onderzoek doen een schildklierdysfunctie vermoeden. Dit vermoeden wordt bevestigd door middel van verder aanvullend onderzoek. In de meeste gevallen zal een medicamenteuze behandeling van de dysfunctionerende schildklier de stemmingsstoornis verbeteren of zelfs geheel doen verdwijnen (Wilson en Jefferson, 1985). Het medische model is in dit geval functioneel en effectief.

Laten we nu ditzelfde model toepassen op een chronische depressieve patiënt die eenzelfde klachtenpatroon vertoont. Ook bij deze patiënt blijkt er bij onderzoek sprake te zijn van een dysfunctionerende schildklierfunctie. In dit geval resulteert een medicamenteuze behandeling van de schildklier op zijn best in een lichte verbetering van het depressieve toestandsbeeld (Wilson en Jefferson, 1985). Volgens het dualistische medische model wordt dan de volgende hypothese geformuleerd: "Persons with longstanding hypothyroidism are less likely to show improvement suggesting that chronic deficiency of thyroid hormone leaves a residual C.N.S. deficit" (Wilson en Jefferson, 1985). Met andere woorden, de langdurige stemmingsstoornis wordt veroorzaakt door een langdurig verminderd actieve schildklier. Chronisch tekort aan schildklierhormoon beschadigt het hersenweefsel. Dit laatste voorbeeld illustreert dat het toepassen wan het dualistische medische model bij chronisch psychiatrische problemen een over-simplificatie aanbrengt die niet meer effectief is. Aangetekend moet daarbij worden dat juist omdat het medisch model vaak weinig effectief lijkt bij chronische 
psychiatrische problematiek de neiging ontstaat om het opsporen van lichamelijk dysfunctioneren maar helemaal na te laten.

Bij de groep chronische psychiatrische patiënten is er behoefte aan een praktisch diagnostisch model. Dit model dient simpel te hanteren te zijn zonder de te modelleren problematiek te oversimplificeren waardoor belangrijke probleemgebieden van de patiënt worden veronachtzaamd.

\subsubsection{Het systeemmodel}

In paragraaf 1.2. is de systeemtheorie al genoemd als een bruikbaar model om de complexe problemen van chronische psychiatrische patiënten te ordenen.

Een tweede eigenschap van het (sub)systeemmodel schuilt in de aard van de wisselwerking tussen de elementen van elk systeem waardoor de elementen in een dynamisch evenwicht blijven met elkaar en het systeem met zijn omgeving (steady state).

De aard van de wisselwerking tussen de elementen, in het geval van de Probleemanalyse de vier nivo's van functioneren, is cybernetisch en complementair. Deze begrippen zijn ontleend aan de cybernetica (stuurkunde) die ontstond in de 40er jaren; dezelfde periode waarin het systeemdenken van Von Bertalanffy ontstond. Binnen het kader van de Probleemanalyse zal ik deze wisselwerking beschrijven aan de hand van de cybernetische theorie van Keeney (1983). Elk van de vier nivo's, en op hun beurt de vier nivo's met hun omgeving, maken deel uit van een zogenaamde regelkring, waarbij effecten bijgestuurd worden door terugkoppeling van de norm op elk nivo. Is er sprake van een negatieve terugkoppeling dan blijft de hele structuur in evenwicht; in geval van positieve terugkoppeling raakt het systeem uit evenwicht en zal een nieuwe stabiele structuur moeten worden gevonden.

Figuur 3 geeft dit regelmechanisme schematisch weer. 
Figuur 3: Cybernetisch regelsysteem

STABIEL SYSTEEM

INSTABIEL SYSTEEM

nieuw systeem met nieuw evenwicht?

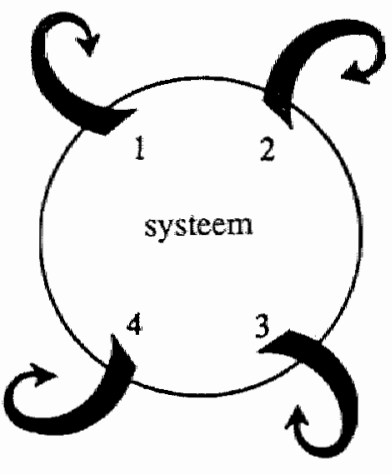

Een systeem met een dynamische maar stabiele structuur, in stand gehouden door negatieve terugkoppelingsmechanismen.

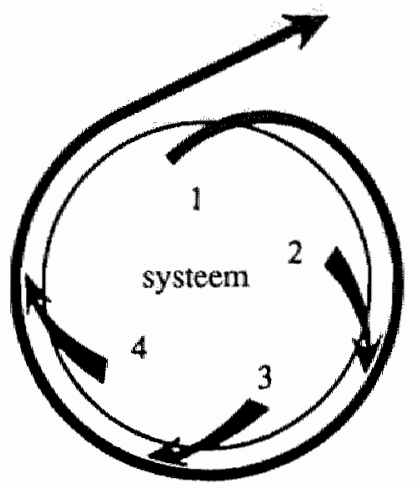

Een systeem met een dynamische maar instabiele structurur. De positieve terugkoppelingsmechanismen versterken de instabiliteit hetgeen kan resulteren in een nieuwe structuur.

$1,2,3$ en 4 verwijzen naar de vier nivo's van functioneren.

Ter illustratie van een dergelijk regelsysteem dient het volgende voorbeeld uit het dagelijks leven.

U zit met uw gezin inclusief hond in de auto op weg naar een zonnige vakantiebestemming. Het weer wordt langzaam beter, de zon gaat schijnen en $U$ raakt al aardig op weg naar de bestemming. Met de stemming stijgt ook de temperatuur in de auto. $\mathrm{U}$ doet het raampje wat open en heerlijke koele wind verkoelt de auto. De negatieve terugkoppeling is in dit geval het openzetten van het autoraam. Het evenwicht blijft 
bewaard de temperatuut in de auto wordt weer aangenaam en $U$ kunt het raam weer sluiten.

Nu raakt $U$ in een lange file: de zon brandt inmiddels op het dak, u opent opnieuw het raam. De buitenlucht is inmiddels even warm geworden als de temperatuur in de auto en omdat de auto ook nog langzaam rijdt, af en toe zelfs stil staat, geeft deze handeling geen verkoeling. De hond in de auto begint fors te hijgen en te kwijlen. De kinderen zijn nu voortdurend met elkaar an het bekvechten, uw vrouw ligt achterover met een hoofdpijn aanval en $U$ ergert zich en zoekt krampachtig naar de mogelijkheid uit de file te geraken. De motor hapert, hilj loopt warm, uw achterligger claxonneert omdat U niet genoeg aansluit bij uw voorligger.

Het openzetten van het autoram heeft de temperatuur niet doen dalen, integendeel, hij stijgt! Van evenwicht is geen sprake meer: wat moet er gebeuren?

In hoofdstuk 8, de witleiding, wordt de rol die lichamelijke ziekte kan spelen binnen het gehele probleemveld van de patiënt met behulp van het systemische model geillustreerd aan de hand van de ziektegeschiedenis uit dit hoofdstuk.

\subsection{Situering van het onderzoek}

Het in dit proefschrift beschreven onderzoek vond plaats in een RIAGG (Regionale Instelling voor Ambulante Geestelijke Gezondheidszorg) die behoudens Maastricht, een middelgrote stad (115.000 inwoners), ook het heuvelland van Zuidelijk Zuid Limburg, ten zuiden van de lijn Meerssen, Valkenburg, Vaals (87.000 inwoners) tot zijn verzorgingsgebied mag rekenen.

Een RIAGG is een onafhankelijke stichting die gefinancierd wordt uit de AWBZ (Algemene Wet Bijzondere Ziektekosten). Deze ambulante instelling kan gezien worden als complementair aan het APZ (Algemeen Psychiatrisch Ziekenhuis) en de PAAZ (Psychiatrische Afdeling van een Algemeen Ziekenhuis).

De RIAGG is opgebouwd uit een aantal afdelingen. De Sociaal Psychiatrische Dienst, een van die afdelingen, is de lokatie van dit onderzoek. Deze afdeling legt zich speciaal toe op de behandeling van ambulante chronische psychiatrische patiënten. De omschrijving van deze patiènten lijkt te verwijzen naar een vrij homogene groep vergelijkbaar met langdurig opgenomen psychiatrische vaak schizofrene patiënten (de Ruiter en Henkelman, 1989). Dit is zeker niet het geval (Romme, 1987; Bachrach, 1988). In tegenstelling tot de 
chronische patiënten zoals wij die uit de kliniek kennen zijn de psychatrische diagnoses van de chronische sociaal psychiarrische patienten heterogeen, evenals hun psychiatrische voorgeschiedenissen, hun secundaire stoornissen en de benodigde psychiatrische zorg. De doelgroep van de Sociaal Psychiatrische Dienst van de RIAGG Maastriclat bestaat voor een deell uit de zogenaamde "draaideur patienten", die regelmatig kortdurend worden opgenomen in een psychiatrisch ziekenhuis. Onze doelgroep patiënten hebben vaak meerdere behandelingspogingen achter de rug, al of niet gepaard gaande met opnames; dagbehandeling of structurering door middel van het aanbieden van een zinvolle dagvulling.

Voor verwijzing naar onze Sociaal Psychiatrische Dienst gelden drie belangrijke criteria: een psychiatrisch toestandsbeeld, stoornissen op andere probleemgebieden dan het individueel psychologische nivo en meerdere behandelingspogingen voor aanmelding. Deze drie criteria zijn ontwikkeld omdat er door onder andere deinstitutionalisering en terughoudend opnamebeleid een vaak moeilijk beinvloedbare groep patiënten ontstond waarvoor voorzieningen geschapen moesten worden.

Misschien is de beste benaming voor deze groep patiënten die van Wing en Morris (1981): "new long term patients". De stigmatiserende term "chronisch" wordt daarmee vermeden. Gegeven de continue inflatie waaraan negatief beladen termen onderhevig zijn is het onvermijdelijk dat op de langere duur ook de benaming "nieuwe lange termijn patiënten" hetzelfde stigma zal gaan dragen als het woord chronisch nu heeft (Bachrach, 1988). Daarom heb ik gekozen voor het handhaven wan de term chronische psychiatrische patiënt.

Om ervan verzekerd te zijn dat alle voor dit onderzoek uit te nodigen patiènten ook daadwerkelijk aan de gestelde chroniciteitscriteria voldeden werd een extra criterium gehanteerd. Alleen die patiënten die gedurende én jaar onafgebroken onder behandeling waren bij onze Sociaal Psychiatrische Dienst kwamen in aanmerking voor onderzoek. Hieraan bleken 218 van de ingeschreven patiènten te voldoen. Via de hulpverleners van de sociaal psychiatrische dienst werd aan deze patiënten gevraagd deel te nemen aan het onderzoek. Het lichamelijk onderzoek werd in de periode november 1986 tot november 1987 uitgewoerd in het lokale academisch ziekenhuis door én en dezelfde internist. Dit onderzoek bestond wit een gesprek met deze internist, een standaard fysisch diagnostisch onderzoek door dezelfde internist, gevolgd door standaard aanvullend bloed en urineonderzoek, alsook een electrocardiogram (ECG). Dit onderzoek kostte elke patiënt ongeveer twee uur. Gedurende de hele procedure vulde zowel patiënt, de hulpverlener, alsook de internist twee vragenlijsten in, te weten een klachtenlijst betreffende lichamelijk 
welbevinden (zie hoofdstuk 6) en een overeenstemmingshijst (zie hoofdstuk 7). Elke patidut werd tevens gevraagd toestemming te geven om gegevens te verkrijgen wan zijn of haar huisarts. De uitslagen van het lichamelijk onderzoek werden na enkele weken door de direct betrokken onderzoekers mondeling besproken (P. Pop, intemist en A. Honig, sociaal psychiater). De bevindingen en conclusies werden spoedig daarop zowel mondeling medegedeeld aan de betreffende hulpverlener en zijn/haar patiënt, alsook schriftelijk aan de huisarts van de patientit.

\subsection{Voorbeschouwing}

In dit hoofdstuk heb ik getracht $U$ een duidelijk beeld te schetsen wan de omvang van het onderhavige probleemveld: de omgang met lichamelijke problemen van ambulante chronische psychiatrische patiênten. Dit betrof zowel de vraag hoe lichamelijk onwelbevinden bij deze patiëntencategorie wordt herkend als ook wat de mogelijkheden zijn om dit onwelbevinden te verminderen. Ik heb $U$ daarbij aan de hand van de beschreven casus proberen duidelijk te maken dat het soms moeilijk is om dit onwelbevinden op te merken en er iets mee aan te kunnen vangen. Mede gezien de zeer bescheiden beschikbare hulpmiddelen voor verdere diagnostiek.

De door mij opgeworpen vragen zullen in de komende hoofdstukken systematisch worden onderzocht en zo mogelijk worden beantwoord. Wanneer $U$ deze hoofdstukken bekijkt zult $U$ bemerken dat de hoofdstukken twee tot en met zeven in artikelvorm geschreven zijn. Deze artikelen zijn reeds gepubliceerd, of worden dat binnenkort.

Proefschriften worden slechts in beperkte kring gelezen en zijn slechts moeizaam verkrijgbaar buiten de universiteit waar het proefschrift ontstond. Het was mijn bedoeling mijn bevindingen zo snel mogelijk en zo breed mogelijk met anderen te delen. Het moeizame pad van artikelen schrijwen en aanbieden aan tijdschriften ter publikatie lag dan voor de hand. Het merendeel van deze artikelen is gepubliceerd in de wetenschappelijke voertaal, het Engels. Om eenheid tussen deze artikelen te behouden zijn alle artikelen in dit proefschrift in het Engels afgedrukt. Daar waar Nederlandse artikelen in het Engels zijn vertald is de Nederlandse tekst zoveel mogelijk gevolgd. In de reeds gepubliceerde artikelen zijn alleen de talal- en telfouten hersteld.

Het opnemen van artikelen in dit proefschrift heeft geleid tot voor sommige lezers mogelijk storende herhalingen in hoofdstuk 2 tot en met 7, zoals de beschrijving van de onderzoeksopzet en -populatie. Hiervoor bied ik U bij woorbaat mijn excuses aan. 
Waar mogelijk worden afkortingen en vakjargon vermeden en wordt een ninder formele schrijfstijl gehanteerd om de toegankelykheid van dit proefschrift voor werkers in de sociaal psychiatrische praktijk te vergroten. Bij het lezen van hoofdstuk 2 tot en met 7 zal U opvallen dat in de opvolgende artikelen de ideeen van de auteurs over de omvang van en de omgang met lichamelijke klachten en ziekten geleidelijk aan veranderen tot de in hoofdstuk 8 genoemde definitieve conclusies. Dit aanschouwelijk gemaakte proces van meningsvorming hangt nauw samen met het schrijven van artikelen in de elkar opvolgende fasen van het onderzoek.

Tenslotte worden in hoofdstuk 9 aanbevelingen gedaan aan hulpverleners in de ambulante geestelijke gezondheidszorg om tot een betere omgang met en screening van lichamelijke ziekten te komen.

Dit proefschrift heeft als titel "Mind the body". Deze titel heb ik gekozen om zijn dubbelzinnigheid. Het geeft enerzijds het dualisme aan dat het "lichaam en geest" probleem oproept; anderzijds is het een oproep aan hulpverleners in de geestelijke gezondheidszorg om meer aandacht te geven aan de omgang met lichamelijke problemen van hun patiënten. 


\section{PROBLEM ANALYSIS: AN INSTRUMENT IN THE REHABILITATION OF CHRONIC PSYCHIATRIC PATIENTS IN THE COMMUNITY}

Probleemanalyse als onderdeel van de omgang met chronische psychiatrische patiënten in de ambulante geestelijke gezondheidszorg

A. Honig, S. Radstake, M.A.J. Romme, M.G.G.J. Breuls

The International Journal of Social Psychiatry, 33, 4, 303-311, 1987

\section{SUMMARY}

In the light of governmental policy in European countries to enhance and reinforce community psychiatric services, the need to introduce a more systematic approach in the treatment of chronic psychiatric patients by the community psychiatric services is currently being stressed. In this paper the problem analysis (P.A.) is described. It is a practical, treatment-oriented instrument which methodically compiles information on chronic patients and their systems. The systematic acquisition and examination of such information provide clues to a rational rehabilitation plan, one that can be carried out by a multidisciplinary community psyciatric service. Such an approach has the added advantage of making education and research in the field feasible. 


\section{INTRODUCTION}

Inadequate care of chronic psychiatric patients discharged into the community a lack of direction in formulating psychiatric rehabilitation policy are critical comments at both Government level (House of Commons Social Services Committee, 1985) and by workers in the field (Dingwall, 1987). Despite this criticism reduction of psychiatric inpatient facilities coupled with a further development of community psychiatric services is still a main Governmental policy in European countries. (Dutch Dept. of Science, Public Health and Culture 1984). What such a community service should embody is still a source of dispute.

In community psychiatry a systematic, methodological treatment model for chronic patients is not yet available. The literature on this subject deals either with epidemiological surveys of prevalence, incidence, and the course of certain psychiatric illnesses (Brown \& Harris, 1978; Strauss \& Carpenter, 1977), or with the desirable structure and organization of community psychiatric services for the chronic patient (Bachrach, 1983).

Considerably less attention is paid to actual treatment, although certain aspects have, indeed, been examined and reported on (Test \& Stein, 1978; Leff et al., 1982). Some conceptual frameworks of the chronic mentally ill were elaborated on in Great Britain by Wing \& Morris (1981) and in the U.S.A. by Adler (1984). Both frameworks, however, though carefully thought out, lack a practical protocol.

Up until now, a systematic and practical inventory, assessing the main problem areas of the chronic patient, has not been available. Consequently, knowledge of this group of patients has been limited and rather inaccessible to education and research. The Department of Social Psychiatry of the State University of Limburg, in cooperation with the community psychiatric services of Maastricht, the Netherlands, has designed such a systematic inventory which is usable in the management of the chronic psychiatric patient living in the community.

\section{PROBLEM ANALYSIS (P.A.)}

In order to systematically gather information and explore the problems of chronic psychiatric patients living in the community, the authors created a semi-structured inventory covering 3 main aspects: 
1. the psychiatric history of the patient;

2. 4 levels of functioning of the patient, and

3. the competence of the patient.

The P.A. has been designed as a practical, treatment-oriented instrument, with manageability by all workers in a multi-disciplinary community psychiatric team as one of its major goals. Information can be contributed from anyone the therapist thinks fit, ranging from referting hospital, family members and neighbours to the local policemen on the beat. The P.A. does not function as a research instrument or a rating scale; rather it is an invertory with open-ended questions, which can be completed within 3 months of regular patient care. In this paper we will elaborate on the 3 above-identified components and present sample questions.

\section{The psychiatric history}

The formost reason for obtaining information about a patient's psychiatric history should be to enable the therapist to learn from the experience of that history and thus to develop a new strategy which is more likely to succeed than previously. With chronic patients in particular, it is important to obtain a clear insight into those factors which have contributed to the process of chronicity. Patient-specific traits (i.e. primary handicaps due to the actual illness process), therapy-specific traits $s_{*}$ and traits concerning the interaction between patient and therapist are among the relevant factors.

To illustrate this with an example; in reviewing long psychiatric histories, the main trait of many subsequent treatments can be described as "more of the same". The patient only switches from one therapist to another, while time and again the same strategy is employed, leading to the same problems found in the previous treatment efforts. Additional literature on "staff burn-out" (Intagliate \& Baker, 1983) emphasizes the importance of long-term case management traits.

\section{4 levels of functioning}

The authors chose a systematic approach, similar to that of won Bertallanfy (1950) to the description of the problems of the patient and his system. This approach was used as an explanatory principle but also as an organizational principle. This theory organizes 
systems in order of complexity and comprehensiveness, Starting at the level of atoms and moving through cells, organs, individuals to family, subculture and finally society (Engel, 1980). Each system affects and is influenced by other systenx in a thierarchical manner.

Our model based on this theory is cybernetic and operates in one of two ways: either by providing negative feedback between the various systems in a stable structure or by providing positive feedback which can amplify minor dysfunctions and cause instability and the possible development of a new structure.

Engel elaborated on systems theory in a different setting and described a case history by means of this theory (Engel, 1980).

In community psychiatric practice, Romme et al. (1981) described 4 levels of functioning within this systematic framework which are used in the current version of the P.A. These are the somatic level, individual level, microsocial level and the mesosocial level.

Figure 1: levels of functioning

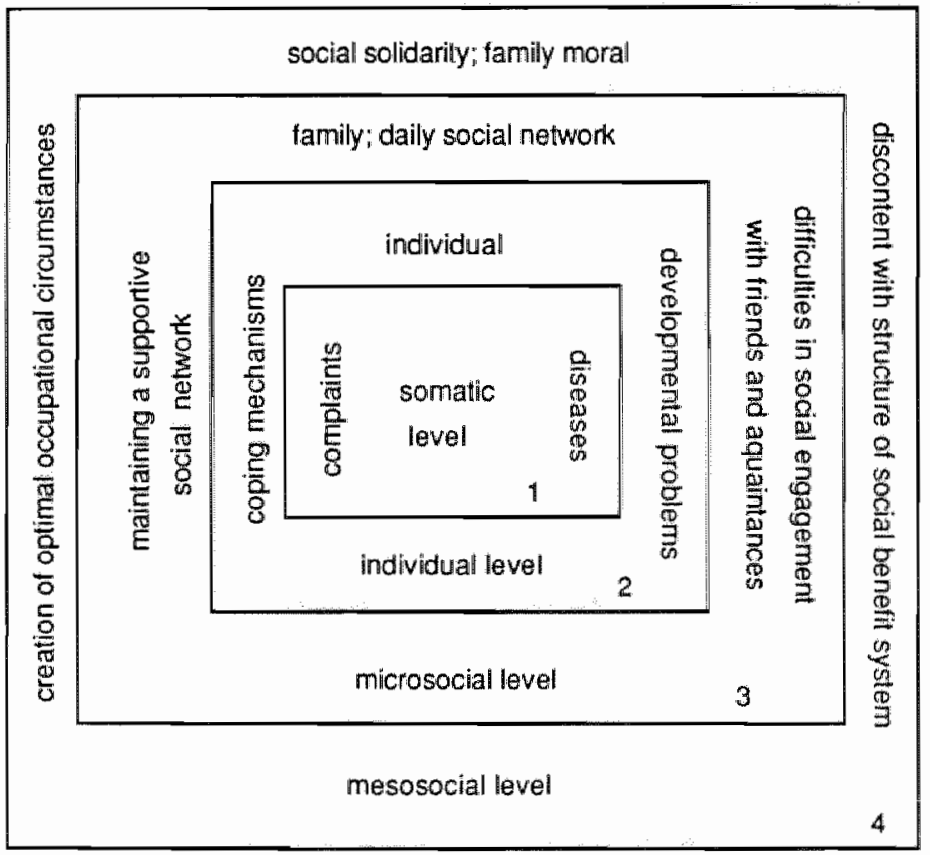


At each level of functioning a certain explanatory principle was arbitrarily chosen. The princples chosen were those most often applied by our team of community psychiatric workers and researchers. They also allowed space for the descripition of individual philosopthies or views at every level of functioning. This was done in order to have the P.A. correspond with the views and philosophies of those working with it. A therapist might, for instance, not work with Erickson's developmental model ( 2 nd lewel) but rather with a behavioural developmental model. The P.A. offers such alternatives.

The accumulation of information per level of functioning is as follows:

\section{Level 1: The somatic level}

At the somatic level, physical complaints and illnesses are the focus of attention. The therapist is asked to describe these complaints and illnesses and, at the same time, determine their origin. If this is not clear, the therapist is then asked to note what steps be is planning to take in order to clarify the cause of dysfunction at this level (This often involves an affirmation or exclusion of physical dysfunctionsy. Such steps may involve obtaining information directly from the patient or consulting with the patient's G.P. or specialist.

Questions at the somatic level include:

- if symptoms are of an orgamic mature, is there any reason to pay attention to them in your therapy?

- if a functional disorder has been diagnosed, do you intend to treat this disorder on the somatic level (e.g. with relaxation training, psychotropic drugs)?

\section{Level 2: The individual level}

At the individual level, our focus shifted to a systematic description of psychopathology on the one hand, and to the detection of possible developmental disturbances on the other. The most important and obvious justification for this choice is the frequency of psychopathology and developmental disturbances found in our patient group.

In the definition of psychopathology, a classification according to the diagnostic criteria from DSM III (American Psychiatric Association, 1980) Axis II and II was chosen. The therapist is first asked to describe psychopathology, psychiatric syndromes and a personality disorder, if present. Approximately $20 \%$ of our chronic community 
psychiatric patients prove to be mentally handicapped, and the P.A. must also take this assessment of mental handicap into consideration.

The second part of the description at the individual level refers to possible developmental disorders. It is accompanied by a guideline for taking a biographic history by means of a short description of the developmental stages described by Erickson (1963).

\section{Level 3: The microsocial level}

At the microsocial level, the primary issue is the identification of problems in the interaction between the patient and his social network. Here, the problem analysis focuses on 3 elements:

1. a factual description of the family in the broadest sense of the word. Most often this will involve the tradional family; however, in the case of singel persons living in boarding houses, fellow occupants might form the actual "family".

2. A description of the most prominent interaction patterns within the involved family.

3. A description of the social network of the patient i.e. those who have an important role in the maintenance of the patient's social equilibrium or the fulfillment of certain needs of the patient. People falling into this category may range from the G.P. to the policeman on beat.

\section{Family description}

Gathering information on major role models for the patient is necessary because these people may play an important role in many community psychiatric strategies. Giving direct support in times of crisis, providing shelter, and securing a job for a patient are examples of community psychiatric strategies.

\section{Interaction patterns}

Here we use the concepts used in communication theories and family therapy. The therapist is asked to give a description of the family in interactional terms. An explanation of the P.A. is given in the form of an observation scheme, as proposed by Cleghorn $\&$ 
Levir (1973) and Boeckhorst (1980). A modified scheme allows the therapist to conie to some conclusions as to the structure of the patient's system, relationships within that system, main themes and dogmas of the family, delineation, and conflict regulation of a system. It is not our intention to initiate family therapy. Our intention is, however, to help the therapist focus on families of the chronic patient. One might, for instance, attempt to detect stereotype, and rigid interactions or a high level of "Expressed Emotion" (EE) (Leff et al., 1982), which might suggest a possible treatment plan. A question typically asked is:

- What is the hierarchical position of the various members within the particular system?

- Who for instance, is the leader of the system, and what is the patient's relationship to this person?

\section{Social network}

Because the social network surrounding many chronic patients often becomes diminished and is taken over by therapists and their services (Speck \& Atmeave, 1973), an exact analysis of the social networks of our patients is vital. Therefore network strategies play an important role in community psychiatry.

We use the classification in sectors by Erickson (1975) for a systematic description of these networks. The classification includes a kinship sector, a friendship sector and a service and caregiving sector. We take this classification a step further by dividing the functions which people in each sector fulfil into affective needs, identification needs, material needs, and social obligations. This part of the P.A. includes a short explanation of each of the above-mentioned classifications. Two illustrative questions from this section are:

- Which of the patient's relatives keep in contact with him? What is the significance of these contacts for the patient Have there been any changes in this sector?

- Which of the following figures representing authority does the patient interact with: his employer, the local police officer, his physician? Have there been any changes in this sector? 


\section{Level 4: The mesosacial level}

The degree to which a patient is able to function in his community depends not only on the social problems he has but also on his particular position.

Social changes and traumas principally influence the patient's mental health in a subjective way and have consequences that are significant on the somatic, individual, and microsocial levels.

This leads to P.A. questions such as:

- Which important events have occured in the life of this patient?

- What were the psychological consequences of these events for the patient (e.g. pathological mourning, paranoid reaction)?

- What were the social consequences of these events for the patient (e.g. social isolation, budgetary problems)?

The authors' impression is that the relationship between the moment the above-mentioned events occurred and the beginning of the help-seeking behaviour is very important, particularly since the consequences of social problems are only felt in the long run. Therefore, the next P.A.-question to be asked is:

- Do the events described earlier and their consequences have any relationship to the onset of the help-seeking behaviour? If so, describe this relationship and note if you are in agreement with your patient.

This part of the P.A. ends with the question:

- Which consequences do you want to act upon and how?

Special attention is focussed here on the possibility of compensating for losses suffered (often the loss of work and the loss of structure and meaning in one's life) and on the possbility of promoting the social interests of the patient.

\section{The competence of the patient}

We define competence as the ability to act when confronted with stimulus. In the P.A., a distinction is made between role competence, coping competence, and competence in the "sense of control". Role competence is defined as the ability to adequately fulfil a social role; coping as a form of competence which refers to the way in which people handle problems. Competence, in the sense of control, is defined by the possibility of feeling 
able to control a given situation, parallel to the internal/external locus of control theory (Rotter, 1966).

Some of the findings of our problem descriptions on the 4 levels involve a form of competence (e.g. the level of intelligence, the presence of a handicap). The following are examples of questions related to the above defined forms of competence:

- In what important role does the patient exhibit a dysfunction?

- Is there a fixed pattern evident in the handling of problems, or is there a flexible style of handling problems?

- Does the patient show a sense of competence in, and mastery of, his life, well-being in his environment, and concern with the overall outcome of his life?

\section{P.A. intake notes}

Once the P.A. is completed and discussed in the team a working hypothesis is formulated consisting of considerations as to the main problems and the mechanisms causing lasting instability. A treatment programme with goals in both short and longer term is thereafter designed.

An example of such a final formulation and treatment plan is given in figure 2 .

\section{FOUR YEARS OF EXPERIENCE WITH THE P.A.}

A criticism which can be levelled at P.A. is that it is a method of assessment already in use by many in - and out-patient services and not more useful than standard psychiatric, social and functional assessments. The general notion of a multi-level descriptive scheme and a treatment oriented record has been thought of as already integrated in daily practice. What, in effect, is new in this approach? 


\section{P.A. intake note}

Name: Mrs. J. Brown

D. $0.13: 17-2-50$

Marital statws: divorced

Referring agent: local Psychiatric Hospital, acute admission ward.

G.P.: Dr. Engel
Pallent number:

87.32 .206

Therapist: Haveis

Date of ntmke: 232,8 ?

Date: $15-6-87$

Reason for referral: frequent compulsory admissions: non attendance O.P. Clinic: non compliance with medication.

Reason for client to seek help: wants rehousing; wants to be discharged from hospital.

Short summary of psychiatric history: 5 admissions during last 3 year with a recurrent acule psychosis, accompanied by drifting- and sexually disinhibited behaviour.

Therapies: compulsory admission with antipsychotic medication; rapid remissions 1 year ago; intividual contacts for $6 / 12$ with social worker.

Main dysfunctions on levels of functioning:

somatic levell

hypertension regulated by medication as prescribed by G.P.

Tension headaches. approx. twice weekly.

Individual level

Only child: uneventful upbringing difficulty in maintaining lasting intimate relationships except with her only child, a son of $18 \mathrm{y}$. old.

DSM III: Axis I atypical psychosis

Axis II none

Microsocial level

Living with son in a small lerraced councill house. No family contacts; contact with a former female colleague. Confides in son as if a partner. Negative contacts only with neighbours.

Mesosocial levell

Living on socjal benefit: Ist episode of illness occurred following the break up of a relationship of 1 year standing with a former employer. Employed as a receptionist till the 2 nd episode of IIness. Good

relationship with G.P.

\section{Formulation:}

A 37 year old divorcee, living on social benefit with her 18 y. old son. She has a 3 year history of recurrent psychotic episodes, leading to a rapid decline of her social network, expulsion from the neighbourhood and unemployment.

Unability to maintain lasting and rusting retationships, diminishing complance with treatment.

\section{Treatment goals and means:}

a. short term

working on a therapeutic relationstip with bouth patient and sori. Increase of compliance by offering depot neuroleptimedication via Gi.P. (consultation by ootherapist).

b. longer term prolonging periods of none psychotic state restoring social networks and employment facilitation of a romal leawing thome process of her son.

\section{Co-therapist (if necessary): Dr. Adler}


Four years of experience with the instrument in routine rehabilitation care was obtained. The implementation of the P.A. in the community psychiatric service of Maastricht resulted in

- creating order for the therapist in the chaos of problems the patient and his system presents

- focussing therapists on life domains and problem areas of the patient which were until then not recognised or given attention

- a systematic recording of, and communication on, often very complex rehabilitation problems

- the formulation of a well founded rehabilitation programme.

On the other hand the P.A.

- is time and energy consuming ( 2 to 4 hours spread over a 3 month period)

- sometimes evokes feelings of insecurity, especially when level of functioning of patients are assessed on which the therapist involved assumes lack of factual as well as professional background

- reduces the possibility of a free and personal overall formulation of the rehabilitation problems the patient presents.

As far as training and research purposes are concerned the P.A. proved to be very useful. Trainees in the rehabilitation of chronic psychiatric patients irrespective of professional background, experienced the P.A. as a useful and systematic tool in their assessment of patients.

The P.A. also resulted in 4 research projects and publications involving somatic, social network, sociological as well as psychopathological aspects in the rehabilitation of chronic psychiatric patients.

\section{REFERENCES}

Adler, D.A., Drake, R.E. \& Stern, R., 1984, Viewing chronic mental illness: a conceptual framework, Comprehensive Psychiatry, 25:2, 192-207

Bachrach, L.L., 1983, Planning services for chronically mentally ill patients, Bulletin of the Menninger Clinic , 47, 163-188

Bertalanffy, L. von, 1950, An outline of general system theory, British Journal of Philosophy of Science, 134-165

Boeckhorst, F., 1980, Observatie en analyse van triadische interactiepatronen in gezinnen, T.V. Psychotherapie, jaargang 6, nr. 3: 140 e.v.

Brown, G.W. \& Harris, T., 1978, Social origins of depression, London: Tavistock Publications

Cleghorn, J. \& Levin, S., 1973, Training family therapists by setting learning objectives, American Journal of Orthopsychiatry, 43: 3, 439-446 
Department of Science, Public Health and Culture, 1984, Statement on Mental Health

Dingwall, J.M., 1987, Psychiatric Rehabilitation, Bulletin of the Royal College of Psychiatrists, vol 11, 158-160

Engel, G.L., 1980, The clinical application of the biopsychosocial model, American Journal of Psychiatry, 137: 5, 535-544

Erickson, G.D., 1975, The concept of personal network in clinical practice, Family Process, 14:4, 487-496

Erickson, E.H., 1963, Childhood and Society, New York: W.W. Norton \& Co.

House of Commons Social Services Committee, 1985, Second report from the session 1984/5-Community Care, vol. 1, London, HMSO

Intagliata, J. \& Baker, F., 1983, Factors affecting case management services for the chronically mentally ill, Administration in Mental Health, vol. 11,2

Leff, J. et al., 1982, A controlled trial of social intervention in the families of schizophrenic patients, British Journal of Psychiatry, 141, 121-134

Romme, M.A.J., Kraan, H. \& Rotteveel, R., 1981, What is Social Psychiatry? Samsom, Alphen a.d.Rijn

Rotter, J.B., 1966, Generalised expectancies for internal vs. external control of reinforcement, Psychological Monographs, 80, 7-28

Speck, R.V. \& Attneave, C.L., 1973, Family Networks; a new approach to family problems, New York: Vintage Books

Strauss, J.S. \& Carpenter, W.T., 1977, The prediction of outcome in schizophrenia III, Archives of General Psychiatry, 34, 159-163

Test, M.A. \& Stein, L.I., 1978, Community treatment of the chronic patient; a research review, Schizophrenia Bulletin, vol. 4, 3, 350-364

Wing, J.K. \& Morris, B., (eds), 1981) Handbook of Psychiatric Rehabilitation Practice, Oxford University Press 


\title{
UNDERVALUED OR DENIED PROBLEM AREA
}

\section{SOMATIC DYSFUNCTIONING OF CHRONIC PSYCHIATRIC PATIENTS LIVING IN TIIE COMMUNITY}

Miskend of ontkend probleemgebied

Somatische aandoeningen bij ambulante chronische psychiatrische patiënten

\author{
A. Honig, A.D.M.A.C. Escher, M.A.J. Romme, M.G.G.J. Breuls
}

Tijdschrift voor Psychiatrie, 28, 10, 676-686, 1986

\section{SUMMARY}

Epidemiological data regarding physical diseases of chronic psychiatric patients living in the community are scarce and incomplete, while somatic diseases and complaints in the described population prove to be high. The pilot study described in this study confirms the high prevalence of physical illness and complaints. Research into the factors involved in undiagnosed physical diseases in chronic community psychiatric patients is long overdue. A standard protocol for the evaluation of physical health is unavailable. Somatic screening facilities for psychiatrists working with chronic ambulatory psychiatric patients in the Netherlands are insufficient.

The introduction of a problem inventory designed to systematically collect information regarding the 4 levels of functioning - physical, individual, microsocial and mesosocial of the chronic psychiatric patient living in the community can facilitate an integrative view of somatic problems in the context of the patient's other problems. The problem analysis offers clues to treatment and to a rehabilitation plan in this chronic population. As far as the somatic dysfunctioning of the patient is concerned, a pragmatic approach has been postulated here in which the actual process of somatic diagnosis is described as a specific task of the psychiatrist; the integration of somatic disturbances however, is seen as a specific task of the patient's therapist, regardless of his professional background. This hypothesis is illustrated by 4 case histories. A research project is in progress to define the quantity and quality of physical disease and to develop community psychiatric strategies in the management of physical dysfunctioning of chronic ambulatory psychiatric patients. 


\section{INTRODUCTION}

Psychiatrists frequently do not feel competent enough to come to any definite conclusions as to how to handle somatic complaints and dysfunctions of their patients (McIntyre and Romano, 1977; Patterson, 1978). Nevertheless, psychiatrists are physicians and, therefore, one expects them to have the competence to deal with somatic complaints and dysfunctions and to be able to reach at least some tentative diagnosis. It is also presumed. that they are capable of integrating somatic complaints and dysfunctions into a treatment plan. Yet, their medical training is insufficient to enable them to perform this difficult task (Kohle et al., 1982; Pérez et al., 1985). Thus, in his day-to-day dealings with somatic complaints of psychiatric patients, a psychiatrist must turn to his own experience, or to that of others, often by examining the relevant literature.

The Department of Social Psychiatry of the University of Limburg has, in cooperation with the community psychiatric service of Maastricht, the Netherlands, collected data on various aspects of chronic psychiatric patients living in the community. Information was gathered systematically using an inventory called "problem analysis" (P.A.). This inventory was applied to a group of 100 randomly selected chronic psychiatric patients and includes data on a psychiatric diagnosis according to DSM III criteria, a description of each patient's social network, social/demographic data and somatic complaints and dysfunctions. In all of these patients, the frequency of somatic complaints and dysfunctions, as well as the integration and handling of these somatic complaints and dysfunctions of the therapists involved was explored.

The literature available on the somatic problems of chronic psychiatric patients living in the community, together with our research and experiences, is described and illustrated in 4 case histories.

\section{IDENTIFYING SOMATIC DYSFUNCTIONING}

A clear, positive correlation between somatic dysfunctioning and psychiatric illness has long been recognized (Roessler and Greenfield, 1961; Eastwood and Trevelyan, 1972). The high mortality rate within this patient population indicates the severity of somatic dysfunctioning. The mortality of the chronic psychiatric in-patient, adjusted for suicide and accidents, is higher than for the general population (Babigian and Odoroff, 1968; 
Shinozaki, 1976; Giel et al., 1978; Rooymans, 1983). Quantative epidemiological studies on somatic dysfunctioning of psychatric patients show that $30 \%$ to $60 \%$ of all psychiatric in- and out-patients suffer with some somatic dysfunctioning (Rooymans, 1983; Ananth, $1984)$.

Rooymans also states that, on the average, half of the diagnosed somatic dysfunctioning is overlooked by the physicians involved. One might presume that failing a somatic diagnosis results from insufficient knowledge or a lack of interest in somatic dysfunctioning on the part of the physician-psychiatrist. Undervaluation of somatic dysfunctioning is, however, not only present in the psychiatric caseload but also in thase of GP's (Eastwood and Trevelyan, 1972). Somatic dysfunctioning is not confined to neurological disturbances, as the close association between psychiatry and neurology might lead one to believe. Epidemiological data on the quality of somatic dysfunctioning show that the nature of these dysfunctions covers all medical areas.

A vast amount of literature is available on the somatic dysfunctioning of the chronic psychiatric in-patient; unfortunately very little is available on the chronic psychiatric patient living in the community. Barnes et al. (1983), in a one-time somatic screening of a chronic community psychiatric population, found $26 \%$ somatic dysfunctioning. As a result of this screening, $13 \%$ of the described population received some form of new treatment. Beresford et al. (1985) refered $25 \%$ of his population for further somatic examination after a one-time blood and urine analysis.

The number of somatic complaints and level of dysfunctioning found in a sample of 100 randomly selected patients attending the community psychiatric service of Maastricht was higher. Of these patients, 70 turned out to have somatic complaints, and 30 a previous somatic diagnosis. These data were obtained without a routine physical examination or laboratory investigation. The somatic diagnose had been made by therrapists other than those involved in the community psychiatric service. It is highly plausible that the percentage of somatic dysfunctioning would have been even higher if a somatic screening had taken place (Ananth, 1984).

From these rather sketchy literature data, plus that which we ourselves obtained, the conclusion can be drawn that somatic dysfunctioning represents a quantatively undervalued problem area within community psychiatric services. Practical problems exist at local level, such as the absence of on-site somatic laboratory facilities; access to such facilities is possible only via the patient's GP or a hospital-based specialist, making 
adequate care for chronic psychiatric patients difficult at best. Another local probllem is that until only recently (1986) psychiatrists of community psychiatric services bud no government authorization to prescribe medication:

Should the chronic psychiatric patient living in the community have a regular physical check-up and, if so, how often? Does taking a regular somatic history or a somatic complaint questionnaire (Luteijn, 1979) offer a good alternative? Should this patient population be submitted to a routine blood and urine analysis, as well as to an ECG? Is calling in data from the GP or hospital involwed sufficient? The answers to these questions and a clear protocol for an adequate somatic screening of this population is long overdue.

\section{INTEGRATION OF SOMATIC DYSFUNCTIONING}

Over the last decade, emergency and hospital psychiatry have used the dichotomous medical model (Sandifer, 1977; McIntyre and Romano, 1977; Guze, 1978; Rooymans, 1979a, 1979b; Adler, 1981; Hoffman and Koran, 1984). According to this model, complaints of patients are ordered in terms of symptoms and syndromes, which are thereafter labelled as somatic or psychological in origin. If, by means of this linear-causal method of categorization, it becomes clear that somatic dysfunctioning is present, a treatment is then initiated. When such a linear-causal theory is applied, a percentage of somatic dysfunctioning of $50 \%$ or higher is found and labelled as causative of the psychiatric dysfunctioning (Hall et al., 1980).

Let us illustrate with an example. A man living in the cornmunity without any medical or social help becomes depressed. Physical examination reveals a severe thyroid dysfunction. In most cases, pharmacological treatment of the thyroid gland ameliorates the depression or even cures the affective disorder completely (Wilson and Jefferson, 1985). Let us now use the same example in a chronic depressed patient. A pharmacologicall treatment of the thyroid dysfunction results in only a slight decrease in depression (Wilson and Jefferson, 1985). According to the dualistic medical model, the following unproductive hypothesis is formulated (Wilson and Jefferson, 1985): "Persons with long-standing hypothyroidism are less likely to show improvement, suggesting that chronic deficiency of thyroid hormone leaves a residual C.N.S. deficit". In the psychiatric practice of chronic patients, the medical model is not sufficient and often not succesful. 
Recent American and English publications describe other more applicable conceptual frameworks. Adler (1984) recognizes the inadequacy of the dichotomous medical model when he says: "Considering the chronic patient as an individual adjusted within his life space rather than as a bearer of treatment outcomes has considerable heuristic potential". He describes 9 life domains which might influence the well-being of the individual, among them living gituation, performance behaviors, the socio-cultural environment, and social costs. However, the way in which these life domains can be evaluated, or when dysfunction within these life domains are present, is not described. Adler's concept is certainly very appealing but lacks a practical elaboration. Identical shortcomings exist in the concept of Wing and Morris (1981), who focused on the intertwining of medical and social handicaps for which they recognize 3 causes: psychiatric dysfunctions, social dysfunctions, and reactions to these psychiatric and social dysfunctions.

In order to meet the need for a practical elaboration of an applicable framework for the chronic psychiatric population, the authors have developed an inventory which can evaluate dysfunctions on the various lifedomains of the clinical psychiatric patient living in the community.

\section{THE MAASTRICHT MODEL}

Over the past 5 years, the Department of Social Psychiatry of the University of Limburg, in cooperation with the community psychiatric service of Maastricht, the Netherlands, has developed a systematic inventory for the treatment and management of the chronic psychiatric patient living in the community.

The inventory does justice to the complexity of the problems the patient faces every day and offers starting points for a treatment plan.

Von Bertalanffy's system theory (1950) is used as a planning principal for the basis of this inventory. His theory offers a frame of reference within which data from various sciences are integrated. It presupposes that our environment and the living organisms within it are hierarchically arranged in systems. Each system is defined as a collection of elements, each of which can be described in terms of material and energy. Between each system and its environment exist barriers which are more or less permeable. Interchange between a system and the environment is subjected to certain rules, details of which will 
not be discussed here. In a hierarchy of living systems, various levels of hunononing oun be recognized, as figure 1 demonstrutes

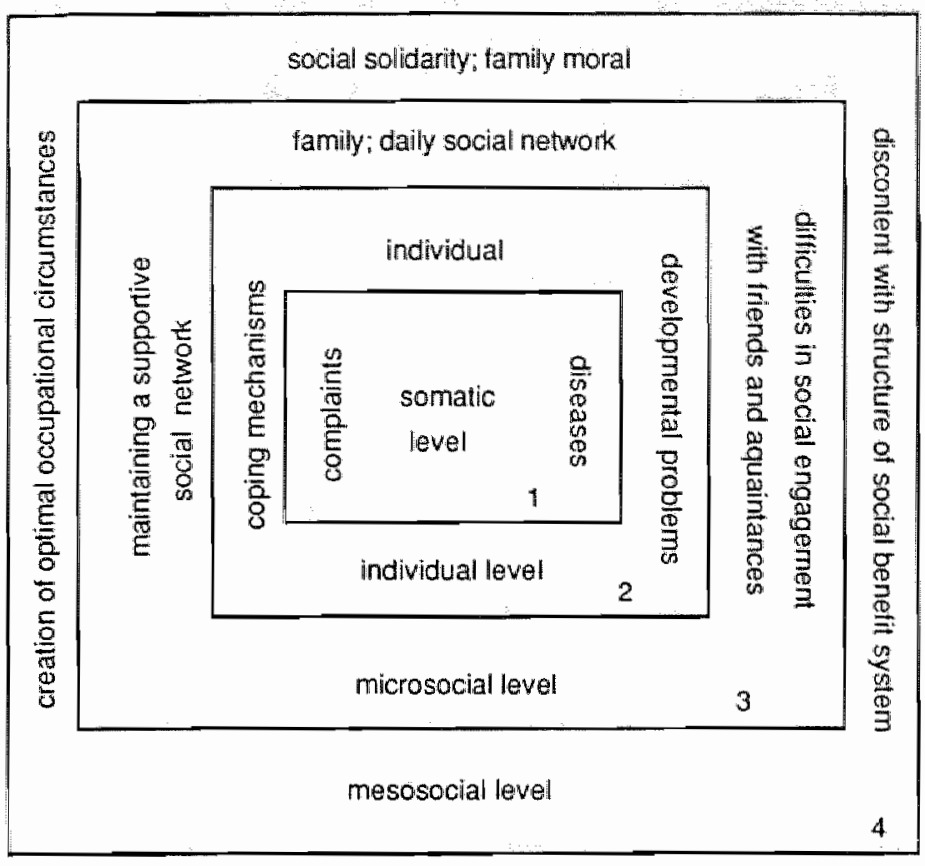

Figure 1 (adaptation from Romme et al., 1981)

According to Von Bertalanffy's theory regarding the chronic ambulatory psychiatric patient 4 levels of functioning are described: (1) the somatic level, (2) the individual level, (3) the microsocial level, and (4) the mesosocial level. The P.A. is the practical elaboration of this theory, evaluating the functioning of patients at these 4 levels. In other words, the P.A. describes the overall functioning of the patient in question. It can be used as a tool to evaluate not only the functioning at each level, but also relate the 4 levels to one another. On the basis of the inventory, a treatment plan can be formulated. Thus, the inventory is useful in daily practice in integrating various problem areas of the patient as well as in the management of warious problems of the patient.

Using the P.A., 100 chronic psychiatric patients living in the community were reviewed. The way in which the somatic level is intertwined with the other 3 levels is described, as is the manner in which the community psychiatric therapists handle the somatic problems and dysfunctions of their patients. 


\section{POPULATION AND SETTING}

Due to certain organizational reasons, the commumity psychiatric service of Maastricht only treats patients with a longstanding psychiatric history with disturbances at more than one level of functioning (Romme et al., 1981). In order to define the nature and severity of the psychiatric disturbances of these patients, diagnoses according to the DSM III Axis If and II (part of the 2nd level) were made for each patient by two different psychiatrists. No agreement could be reached as to the diagnosis for 13 patients and so these diagnoses were deferred.

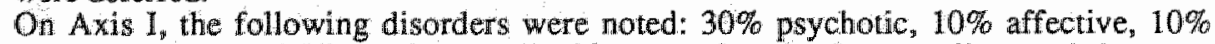
substance abuse and $5 \%$ psycho-organic. $20 \%$ were found to be mentally retarded.

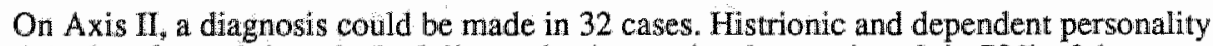
disorders formed the principal diagnosis. As previously mentioned, in $70 \%$ of the cases somatic complaints were noted and $30 \%$ of the total population had been diagnosed with a somatic dysfunction. These dysfunctions were diagnosed by therapists other than those in the community psychiatric service and most frequently by either the patient's GP or a specialist. From the above mentioned reference, the role of somatic complaints and dysfunctions within the overall dysfunctioning of the patient was described.

\section{SOME CASE HISTORIES}

\section{Somatic dysfunctioning as a main focus}

The patient is a 35-year old divorced man, a merchant by trade and father of a teenage girl. He has lived with his elderly mother ever since his divorce a year ago. The patient was diagnosed a few years ago as having osteosarcoma. He has undergone a resection of one of his legs up to the knee. His life expectancy is two years at the most.

A year prior to his referral to our community psychiatric service, this man becomes more and more addicted to pain-killing drugs. These drugs reportedly cause a confusional state and increased isolation. During that time he is often admitted to the psychiatric ward of a general hospital. He feels restricted and threatened by his illness. He demands more and more attention and medication. After a while, his feelings of hopelessness cause his fanily (and friends) to reject him, leading to still more isolation. The patient is referred to the community psychiatric service where a P.A. is done. It results in the following approach. Together with the patient, the therapist draws up a realistic list of goals which the man would like to have fulfilled in the last period of his life. Gradually his behavior begins to change. He is able to diminish his intake of medication and, thereby, the need to be admitted to the hospital. His social isolation decreases and he even restores contact with his daughter. He is able to start a new relationship with a woman and finds a 
temporary job with his brother's firm. Gradually, he comes to a certain acceptance of his fate.

Analysis: somatic complaints can reflect the coping capacity of the patient considerably. A terminal illness may disturb the balance at all levels of functioning. As a consequence, the patient may find himself in an intolerable stalemated position. At the individuallevel, a DSM III diagnosis of histrionic personality disorder and substance abuse is made. At the microsocial level, a severe disruption of family ties, especially with his wife, mother and daughter, has taken place. He is no longer functioning in any social role; he is without a job and he has lost contact with his colleagues. His relationship with the local hospital has become strained and an expulsion process is under way. The rehabilitative therapy has been concentrated at levels 2 and 3 , the initiation of acceptance of his terminal illness and the reconstruction of his social network. With successful rehabilitation at these levels, the terminal illness (dysfunction on the 1 st level), his life and future becomes bearable and eventually acceptable.

\section{Somatic dysfunctioning as a signal}

The patient is a 45-year old, moderately retarded, married man with an adult son. For the past nine years he has been on social benefit because chronic abdominal complaints and depression prevent him from working. He has had a stomach resection twice. This patient is completely idle and isolated all day long. He sleeps poorly and has complained of a loss of appetite for years. His psychiatrist prescribes antidepressants, his specialist in internal medicine antacids. He only leaves home for his out-patient appointments. His wife doess all the talking. She explains that his stomachaches are due to "nerves". "The patient himself expresses his will to get better but otherwise keeps silent. During his eleventh year of treatment, he takes an overdose. After his discharge from the hospital, his wife has a breakdown. She becomes depressed and is admitted to the hospital.

When the wife returns home, a role reversal between the couple takes place. She turns into a somewhat troubled woman. He changes from a passive, handicapped man into an active caring husband. His physical complaints diminish considerably. He decides to gradually stop his antidepressants and is able to break his social isolation. A new equilibrium develops in which the couple help each other and need only minimal directive therapy. 
Analysis: this patient is suffering from long-term dysfunctions an level 1 (stomach complaints, disturbed sleep, and lack of appetite) and level 2 (depression). He receives specialized treatment for the complaints at both these levels. A severe disruption at the 3rd level (illness of the spouse) is needed for the patient to reverse his role from needy patient to active, responsible, participating husband. Major changes at the 3rd level diminish dysfunctions at the other levels.

Existing somatic dysfunctioning may sïgnal dysfunctioning at other levels. Somatic complaints refer not only to demonstrative somatic disorder, but also to an unsatisfactory social role or pattem of living. The signal persists as long as this pattern or role persists.

\section{Parallel problems}

This patient is a moderately retarded, 34-year old divorced woman. Since the birth of her son, 10 years ago, she has been known to have recurrent episodes of panic, accompanied by chaotic and destructive behavior. Social, and especially relational, problems are often the precipitants. As a result, she has often been admitted, under various diagnoses, to mental institutions for prolonged periods of time. The patient has, for the past three years, been living on her own with her son and boyfriend, following a rehabilitation period in a hostell. With the aid of a structured, directive therapy program, she is able to continue to live in the community and is only admitted twice for brief periods of time. She describes multiple physical complaints which are partly labelled as hyperventilation. Very recently her psychiatrist diagnosed a lumbar disc prolapse. He referred her and she underwent a succesful disc prolapse operation.

Analysis: this patient shows dysfunctions at all 4 levels of functioning. Long-term community-based treatment facilitates a more stable functioning at level 3 (living as a family with son and boyfriend), as well as at level 4 (reintegration into the community). A somatic dysfunctioning may be a problem parallel to dysfunctions at other levels with no direct relationship. Attention and care - in this case, for a somatic dysfunction - may lead to less risk of disruption at other levels of marginal functioning. The coping capacity of a patient can thus be enhanced by facilitating the process of somatic treatment. 


\section{Somatic dysfunctioning as an alibi}

This patient is a 40 -year old married woman without children. At the age of twenty, she develops anti-social behavior, the initial cause of her psychiatric referral. The psychiatrist later diagnoses this woman with epileptic fits of hysterical origin. A subsequent EEG shows a diffuse irritative, non-specific pattern. Anti-epileptic medication does not result in a change in this woman's behavior. Her behavior continues to be intolerable for those around her and so she is compulsory admitted to a chronic ward in a mental institution. After a period of 10 years spent in this institution, the woman decides to discharge herself against her therapists advice and is referred to the community psychiatric service. She marries a fellow patient. A renewed neurological examination does not reveal any signs of epilepsy. Her anti-epileptic medication is consequently stopped. She presently holds a part-time job, runs her own household, and manages her finances successfully.

Analysis: it is difficult to draw any conclusion as to the origin of the behavior problems of this patient 20 years ago. Diagnosed with poorly regulated epilepsy with thysterical overlay, she has been removed from the community for 10 years. Too much emphasis on a somatic dysfunction like epilepsy may lead to a one-sided and restrictive treatment regime. As little attention has been given to problems at the other levels of functioning, chances of a successful recovery are minimal.

\section{CONCLUSION}

The P.A. is a useful instrument, integrating physical dysfunctions with other problem areas of the chronic ambulatory patient. The systemic accumulation of dysfunctions of various origins lead to useful cues for further treatment and rehabilitation; especially those problems which are frequently overlooked can now be included in a rehabilitation plan. Somatic dysfunctioning is one of those often overlooked problem areas. The patient's therapist irrespective of his professional background is able to discriminate physical complaints by means of the P.A. and is the very person to integrate somatic problems in the overall dysfunctioning of the patient. Physical diagnostic procedures should be dealt with by the psychiatrist. Therefore, if by means of the problem inventory a physical disease is suspected, the community psychiatrist should be consulted. 


\section{REWERENCES}

Adler, D.A. (1981). The medical model and psychiatry"s tasks. Hospital and community psychlatry, vol. 32,6,387-392.

Adler, D.A., R.E. Drake and R. Stern (1984), Viewing chronic mental illness: a conceptual framework. Comprehensive Psychlarry, vol, 25, 2, 192-207.

Ananth, J. (1984), Physical illness and psychiatric disorders. Comprehensive Psychiatry, vol $25,6,586-593$.

Babigian, H.M., and C.L. Odoroff (1969). The mortality experience of a population writh psychiatric illness. Am. J. Psychlatry, 126, 470-480.

Barnes, F.B., et al (1983), Medical illness in chronic psychiatric outpatients. Gen. Hosp. Psychiatry, 5, 191-195.

Beresford, T.P., et al (1985), Clinical laboratory data in psychiatric out-patients. Psychosomatics, vol. 26, $9,731-744$.

Bertalanffy, L. von (1950), An outline of general system theory. Brit. J. Philos. of Science.

Eastwood, M.R., and M.H. Tevellyan (1972), Relationship between physical and psychiatric disorder. Psychol. Medicine, 2, 363-372.

Giel, R., et al (1978), Mortality in the long-stay population of all Dutch mental hospitals. Acta Psychiatr. Scand. 57, 361-368.

Guze, S.B. (1978), Nature of psychiatric illness: why psychiatry is a branch of medicine. Comprehensive Psychiatry, 19, 4, 295-307.

Hall, R.C.W., et al (1980), Physical illness manifesting as psychiatric disease. Arch. Gen. Psychiatry, 37, 989-995.

Hoffman, R.S. and L.M. Koran (1984), Detecting physical illness in patients with mental disorders. Psychosomatics, vol. 25, 9, 654-660.

Köhle, K., et al (1982), Integration of the psychosomatic approach with internal medicine: development of concepts and preliminary results of evaluation of doctor-patient interaction. Psychother. Psychosom., 38, 221-230.

Luteijn, F., et al (1979), Enige ervaringen met een klachtenlijst (HSCL). Ned. $T$. Psychol., 34, 167-179.

McIntyre, J.S. and J. Romano (1977), Is there a stethoscope in the house (and is it used). Arch. Gen. Psychiatry, 34, 1147-1151.

Patterson, C.W. (1978), Psychiatrists and physical examinations: a survey. Am. J. Psychiatry, $135,967-968$.

Pérez, E.L. and J. Rassell (1985), Extent of teaching of psychosocial medicine in Canadian medical schools. Psychosomatics, 26, 10, 820-822.

Roessler, R., and N.S. Greenfield, Incidence of somatic disease in psychiatric patients. Psychosomatics Medicine, 23, 413-419.

Romme, M.A.J. et al (1981), Wat is sociale psychiatrie. Samsom, Alphen aan den Rijn, 126-132.

Rooymans, H.G.M. (1979a), Psychiatrie als medisch specialisme I. Ned. Tijdschr. Geneeskunde, 123, 10, 380-383.

Rooymans, H.G.M. (1979b), Psychiatrie als medisch specialisme II. Ned. Tijdschr. Geneeskunde, $123,11,411-416$.

Rooymans, H.G.M. (1983), De verwevenheid van somatische en psychische ziekten I. Somatische ziektebeelden bij psychiatrische patiënten. Ned. Tijdschr. Geneeskunde, 127 , $51,2323-2327$.

Sandifer, M.G. (1977), The education of the psychiatrist as a physician. Am. J. Psychiatry, 134, 1, 50-53.

Shinozake, H. (1976), An epidemiological study of deaths of psychiatric inpatients. Compr. Psychiatry, 17, 425-436.

Wilson, W.H. and J.W. Jefferson, Thyroid disease, behavior and psychopharmacology. Psychosomatics, 26,6 . 
Wing, J.K. and B. Morris (eds.) (1981), Handbook of psychatry rehabilitanon practice. Oxford, University Press. 


\section{PHYSICAL ILLNESS IN THE CHRONIC COMMUNITY PSYCHIATRIC} PATIENT: A CRITICAL REVIEW

Het lichamelijk welbevinden van ambulante chronische psychiatrische patiënten.

Een onderzoeksprotocol.

A. Honig, P. Pop, A.D.M.A.C. Escher, H. Philipsen, M.A.J. Romme

Tijdschrift voor Sociale Gezondheidszorg, 66, 181-184, 1988

\section{SUMMARY}

Somatic care in community psychiatry, especially for chronic patients is only in its infancy. It is not clear whether the responsibility for this problem area lies with the patient's general practitioner (G.P.) or with other services. In the literature, high percentages of physical complaints and illnesses are reported along with high percentages of missed diagnoses by the referring agent or therapist. An inaccurate definition of physical illness might well account for these high percentages. The misinterpretation of available somatic data may also occur as a result of the same inaccurate definition of physical illness. Thus, minor physical abnormalities, disabilities, and abnormal diagnostic test findings may, in fact, account for high percentages of "physical illness". Consequently, the meaning of data on missed diagnoses becomes unclear. The question then arises of whether the high percentages of physical illness and missed diagnoses reflect inadequate care or perhaps an effort to promote the classical medical model in community psychiatry. The need for further research in this area is stressed in order to verify the above criticism. 


\section{INTRODUCTION}

Half of the patients in psychiatric care suffer from a physical illness, a quarter of which are thought to have causal relationships with the presenting psychiatric disease.

The referring agent or therapist involved is, in the majority of these cases, unaware of the coexisting physical illness.

This is the alarming conclusion of wirtually all researchers in the field (Koranyi, 1979; Hall et al., 1980; Hoffman \& Koranyi, 1984; Ananth, 1984). What is the psychiatrist's attitude towards the management of physical illness? According to Rigby and Oswald (1987), psychiatrists in training have enough trouble performing their routine physical examinations adequately. Patterson (1978) concluded from a survey among psychiatrists that they evaluated their own skills in the actual performance and interpretation of a routine physical check-up to be inadequate.

Community care for the chronic patient - the focus of this review - in general does not provide an adequate evaluation of physical well-being, although in a few American states, like Oregon and California (Maricle et al .,1987), some legislative measures have been taken to establish routine physical screening facilities. Many community psychiatric centers still lack basic facilities for carrying out a routine physical check-up. Moreover, community psychiatry, unlike clinical in-patient psychiatry, has no routine protocol for the screening of physical illness.

Community psychiatry often operates with multidisciplinary teams. Within such a team, individual members assume more responsibility for direct patient care and management than do their clinical counterparts. Just how community psychiatric nurses, psychologists, and social workers from such a team should approach the physical complaints and symptoms of their patients remains an open question.

How is it possible that a problem which is regarded by researchers as vast and causally related to the presenting psychiatric problems, as well as to the patient's physical wellbeing, is still largely ignored by those responsible for the organization of care and for the training of therapists themselves? Why haven't those involved in the daily care of these patients responded to the suggestion of such a potential causative, and thereby possibly also curative, factor in the problems they are presented with? Obviously, the daily practice of community psychiatry does not confirm the conclusions of researchers in this field.

A critical review of generally accepted research methods and management aspects of physical well-being, especially of the chronic community psychiatric patient, is 
appropriate in order to determine whether research data might be giving a distorted view of practitioners in this field.

\section{PHYSICAL WELL-BEING}

Chronic community psychiatric patients often express both psychological and physical complaints (Honig et al., 1986; Maricle et al., 1987). How a therapist views the physical well-being of his patients depends upon the theoretical model with which he operates. The traditional medical model is still the most popular. This model operates by means of exclusion. If no causal organic abnormality can be detected for a physical complaint, a psychological or social origin is assumed. Within such a model, a psychological or social treatment approach for physical complaints of patients referred to a community psychiatric center is logical and defendable. "The consequence, however, is that physical complaints are given a psychological and/or social connotation and are thereby disregarded. Hence, patients with physical complaints often feel meglected. In community psychiatric care of chronic patients, the medical model does not suffice to explain the very complex problems in various life domains (Adler, 1984). The more recent biopsychosocial model (Engel, 1977) is better equipped to cope with these complexities. However, this involves a reorientation of one's own current thinking as a therapist. Engel's system theory views illness as a disruption of the biopsychosocial equilibrium. Taking this as a starting point, it is necessary to review all of the variables involved in this equilibrium as well as the relationships between these variables.

The Academic Unit of the Community Psychiatric Service (RIAGG) in Maastricht, the Netherlands developed a problem inventory (Honig et al., 1988). By means of this inventory, one is able to systematically gather information regarding various life domains. We distinguish four such life domains or levels (Fig. 1.):

1. the physical level

2. the individual level

3. the mesosocial level

4. the macrosocial level 
Figure 1:

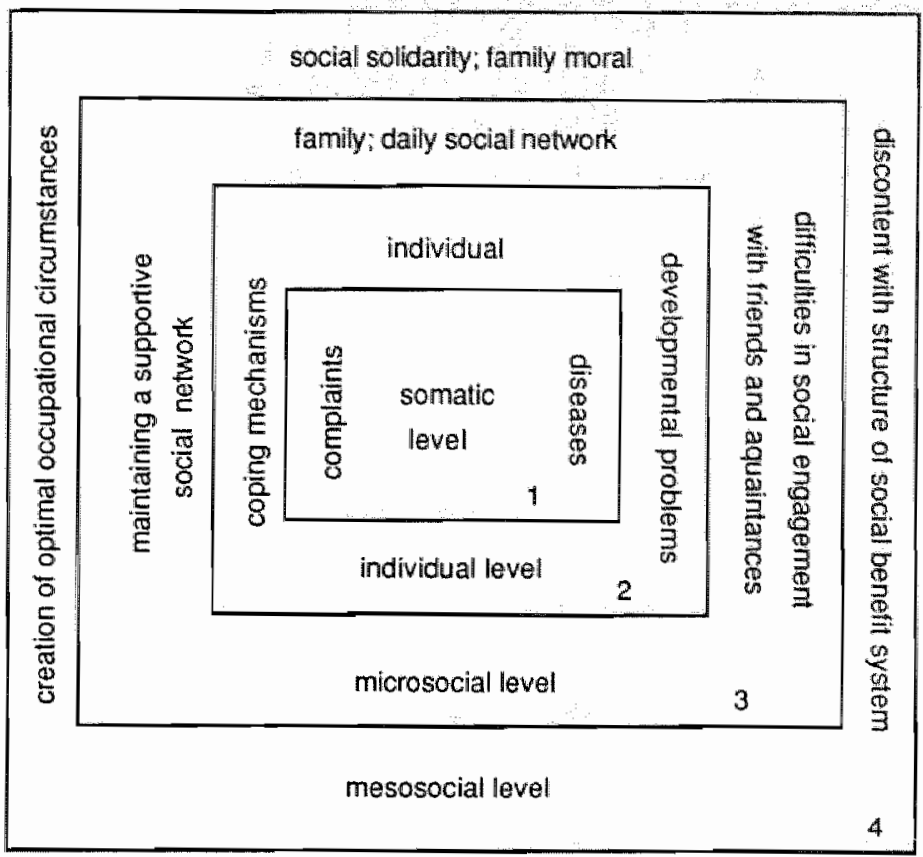

The relationships between and among these four levels are unlike those in Engel's reciprocal model, cybernetic and complementary in origin (Keeney, 1983). The levels are considered to be in equilibrium when they relate to each other by means of a positive feedback loop.

The cybernetic principle is already well accepted in human hormonal regulation models. An example is the thyroid hormone (thyroxine), which is released following the excretion of thyroid stimulating hormone (TSH). The release of this hormone, in turn, depends on the level of thyroid hormone in plasma. A high thyroid hormone concentration results in a decrease of TSH release, a low concentration in an increase. In this way, this hormone system remains in equilibrium. The linear causality which is customary in the medical model $(A \rightarrow B)$, as well as the reciprocal relationships $(A \vec{\sim})$ ) used by Engel $(1977)$, are thereby abandoned, as they lead to exclusion rather than inclusion.

Evaluation of dysfunctions on the somatic level by means of this systematic, cybernatic model is effective since dysfunctioning on this level influences and is influenced by the other three levels. The experiential aspects of physical dysfunctioning are the main focus. 
This is in contrast to the medical model, in which the presence or absence of a somatic abnomality is crucial.

\section{THE CONCEPT OF DISEASE}

Disease. What does it mean? Ever since Hippocrates, the concept of disease has remained a vague notion. To quote Dubos, "The difficulty in defining disease is implicit in the very structure of the word itself" (Dubos, 1968). This statement does not only refer to mental disease but also to medical disease (Clare, 1976). Consequently, the percentages of diseases detected by various researchers in this field depend very much on which definition of disease is applied. In general, the broader the definition of disease, the higher the percentage of disease found. Similarly, the narrower the definition, the lower the percentage disease diagnosed.

In epidemiological research, a clear definition of disease is often omitted. Some authors, however, have tried to define disease according to such criteria as severity of disease (Eastwood \& Trevelyan, 1972) or according to the consequences of the diagnosed disease for an active medical treatment (Hoogduin et al.,1985). Whenever a limited defunition of disease is applied, considerably lower percentages of disease are found.

Reviewing the physical illnesses found in psychiatric populations, one comes across such diseases as lipoma of the back, undescended testicle, hyperlipidemia, atrophy of one kidney, hemorrhoids, hyperostosis interna frontalis, etc. (Hall et al., 1980; Maricle, 1987).

In short, a clear consensus on a definition for physical disease is not present. Sickness, ailment, condition, handicap, and abnormal finding on further examination, are used interchangeably and sometimes (mils)taken for disease.

Details of to the process leading up to a disease diagnosis are, on the whole not unavailable. Furthermore the more laboratory tests one performs, the more false positive abnormal findings one will statistically find. Researchers in the United States in particular apply very extensive series of routine laboratory tests, including computer tomography and sleep EEG (Hall et al, 1980; Hoffman \& Koran, 1984) to diagnose up to $80 \%$ of physical diseases within their psychiatric populations. 
Another problem in coming to a somatic diagnosis is the time factor. A single physieal screening cannot always confirm or exclude a certain disease. A single detection of high blood pressure, for example, is not sufficient to diagnose hypertension. Consequently, during a single physical screening; often only a probable diagnosis can be made. Unfortunately, this degree of uncertainty is hardly ever indicated when percentages of disease are given.

A practical and relevant definition of disease for research purposes should therefore include a physicall illness:

A. for which a patient needs medical treatment and/or

B. is suspected; the patient needs a regular check-up in order to confirm or exclude he suspected somatic disease.

Another important consideration is the difference between physical disease for which a clear physical dysfunction can be diagnosed and the so-called "functional diseases" for which no physical abnormality can be detected but which are every bit as disturbing for the patient.

\section{THE CONCEPT OF MISDIAGNOSIS}

The earlier described semantic problem involving the concept of physical disease clearly extends to the concept of misdiagnosis. In a literature review, Ananth (1984) reported that, on the average, half of the physical diseases diagnosed by researchers go unnoticed to either the therapist or the refening agent.

The definition of a misdiagnosis remains unclear, as the researcher, therapist, and/or referring agent may apply different definitions of disease. Conclusions, however, are not vague at all. "Counselors may choose to take segmental and restricted responsibility for the well-being of their 'clients', but medical specialists and psychiatrists cannot assume a similar posture towards their patients" (Koranyi, 1979).

Hence, the high percentages of misdiagnoses are used to promote the medical model in psychiatry and reserve the handling of the possible physical screening procedures exclusively for the psychiatrist. Papers like Sandifer's "The education of the psychiatrist as a physician" (1977) and Guze's "Why psychiatry is a branch of medicine" (1978) illustrate this tendency. The concept of misdiagnosis, as applied in the literature, could 
therefore be misleading. There are a number of things besides missing a plyysical disease that could be misinterpreted as a misdiagnosis, anong them:

1. the therapist is aware of the physical disorder but, knowing the course of the disorder he does not diagnose a disease, (e.g., a serologic scar from a previous syphilitio infection);

2. the therapist applies another definition of physical disease; and

3. the patient refuses any physical screening procedure;

4. the patient uses available G.P. care inadequately.

For an adequate measurement of misdiagnosis in terms of missing a physical disease in this population, one needs to gather information from the G.P., therapist, and medical screener involved. A clear and common definition of physical disease must be agreed to by all concerned, including a judgment on the certainty and severity of the alleged disease. The percentage would then reflect "misdiagnosis" in the true sense of the word, and the percentages found could very well be much lower than those generally accepted.

\section{MISDIAGNOSING FACILITATING FACTORS}

In the literature, additional factors are mentioned which may be related to failing to establish a physical diagnosis. These factors include the interaction between patient and therapist and specific traits of the patient. These factors will now be discussed.

\section{The interaction between patient and therapist}

When physical disease is screened and described in the literature, the emphasis is generally placed upon epidemiological and organizational aspects of the detection of physical complaints and diseases. Little attention is given to the interaction which should normally precede a diagnostic process, that is, the agreement and degree of consensus of opinion between patient and therapist as to the presence, attribution, and severity of the presenting physical complaint(s). This step is crucial in the process leading up to a satisfactory screening and therapy (Dormaar, 1983). 
Lack of agreement and/or consensus may well lead to inadequate care and, conseguently, to inadequate somatic evaluation. In general, three forms of agreement can be discriminated between patient and therapist:

1. subjective agreement - similarity in the subjective assessment of the other person's opinion on a specific subject. "I think he has the same wiew as I have",

2. agreement on mutual perception - patient and/or therapist give(s) a correct assessment of the other's perception. "His opinion is such; it is contrary to mine"; and

3. factual agreement - the assessment of a factual similar opinion. "He thinks this way and so do I".

These three forms of interaction can be measured by means of a questionnare which is completed separately by both patient and therapist (Fig. 2).

Figure 2. A sample from the agreement questionnaire.

Questionnaire for patient:

\begin{tabular}{|c|c|c|}
\hline statement 1 & my opinion & $\begin{array}{l}\text { How do you think your } \\
\text { therapist will answer this } \\
\text { question? }\end{array}$ \\
\hline $\begin{array}{l}\text { I am physical- } \\
\text { ly ill }\end{array}$ & 12345 & $\begin{array}{lllll}1 & 2 & 3 & 4 & 5\end{array}$ \\
\hline
\end{tabular}

Questionnaire for therapist:

\begin{tabular}{|c|c|c|}
\hline statement 1 & my opinion & $\begin{array}{l}\text { How do you think your } \\
\text { patient will answer this } \\
\text { question? }\end{array}$ \\
\hline $\begin{array}{l}\text { This patient } \\
\text { is physically } \\
\text { ill. }\end{array}$ & 12345 & 12345 \\
\hline
\end{tabular}

1. 2345 refers to graded scale: 1 = complete agreement

$$
5=\text { complete disagreement }
$$




\section{Specific patient traits}

Stigmatizing remarks often made regarding chronic psychiatric patients but seldom systematically investigated which can hinder a somatic screening include:

1. deteriorated cognitive functions, psychological regression, affective deterioration

(Ramsay et al., 1982; Ramsay and Engelsman, 1983);

2. prolonged psychiatric history (Ramsay et all, 1982b); and

3. the impression chronic psychiatric patients tend to make on others, such as:

"malodorous", "dirty", "may not cooperate" (Kampmeier, 1977; Hoffman \&

Koran, 1984), and "unattractive and poor" (Adler, 1972).

In a recent study (Maricle et al., 1987), 43 out of 100 chronic community psychiatric patients indeed declined a medical screening.

A systematic evaluation of these often reported clinical observations is needed in order to set up strategies for an adequate somatic screening of this population. A physician not otherwise involved in the management while screening these patients might well be able to form a more systematic and less anecdotal opinion regarding communicativeness during the interview. He may also be able to systematically gather information on other possible patient traits like memory regarding medical and psychiatric history, physical hygiene and cooperation with the screening procedures.

\section{PROPOSED RESEARCH PROJECT}

The Academic Unit of the Community Psychiatric Service in Maastricht has, in view of the literature and our criticism regarding the applied methods and interpretation of data, set up a research project. This project involves 150 chronic community psychiatric patients. In addition to somatic screening, extensive data will be gathered from both the patient's G.P's and the community psychiatric case managers. Interactional variables between patient and therapist will also be investigated. 


\section{CONCLUSIONS}

Data presented in literature on the chronic community psychiatric patient reveal bigh percentages of physical complaints and diseases as well as high percentages of missed physical diseases. Physical disease is a concept which is hard to define and often open to various interpretations. Only seldom is a definition of, or some criteria for, physical disease given. In cases where this effort has been made, a considerably lower percentage of physical disease is reported, on the average, $20 \%$ less. A definition of misdiagnosis also remains unclear. It appears that the high percentages of physical disease and misdiagnosis generally reported in the chronic community psychiatric patient are being used as an argument to promote the medical model in psychiatry.

This paper raises criticism on generally accepted research methods and outcomes in this field. Physical disease, however, remains an important problem area when one considers the increased death rate for psychiatric patients as compared with that for the general population (after correction for suicide and accidents) (Sims, 1987). Therefore, while this paper is certainly not a plea for "psychiatry unlimited" (Ananth, 1984) it does call for a multidiscipinary management of physical health in such a way that the relationship between therapist and patient is improved and that no unnecessary attention is deflected from other important problem areas of the chronic community psychiatric patient.

Recommendations for a research protocol on the physical well-being of chronic community psychiatric patients are given and include:

1. a clear definition of physical disease as well as of functional disease;

2. a classification of the detected diseases using an international classification of diseases;

3. an indication of severity, duration, and certainty of diagnosis; and

4. a limited standard physical screening procedure, including a standardised physical examination (Summers et al., 1981), basic hematological and biochemical tests, an ECG, and syphilis serology, preferably performed by a physician who is otherwise not involved in the daily care of the patients.

Somatic care in the community psychiatric service, especially for the chronic patient population is still lacking in many aspects. A clear statement of the G.P.'s or Community Psychiatric Service's responsibilities with regard to this problem is not available. A research project such as that described above may clarify the role of physical disease in this patient population. This could result in more adequate physical care of patients by 
community psychiatric workers. Somatic fixation and denial on the part of both therapist and patient could thereby be prevented.

\section{LITERATURE}

Adler, D.A., 1984, Viewing chronic mental illiness: A conceptual framework, Comprehensive Psychiatry $25,192-207$

Adler, G., 1972 Helplessness in the helpers, British Joumal of Psychology, 45, 315-326

Ananth, J., 1984, Physical Illness and Psychiatric Disorders, Comprehensive Psychiatry, 25, 1984, 586-593

Clare, A, 1976, Psychiatry in dissent, Travistock Publications London,

Dormaar, M., 1983, Overeenstemming als proces variabele in onderzoek over psychotherapie en geestelijke gezondheidszorg, (Agreement as process variable in psychotherapy research and mental health care), unpublished manuscript, University of Limburg, Department of Social Psychiatry, The Netherlands

Dubos, R., 1968, Man, medicine and environment, Pall Mall Press London,

Eastwood, M.R. and Trevelyan, M.H., 1972, Relationship between physical and psychiatric disorder, Psychological Medicine, 2, 363-372

Engel, G.L., 1977, The need for a new medical model: a challenge for biomedicine, Science, $196,129-136$

Guze S.B., 1978, Nature of psychiatric illness: why psychiatry is a branch of medicine, Comprehensive Psychiatry, 19,295-307

Hall, R.C.W., Gardner, E.R., Stickney, S.K., LeCann, A.F.,

Popkin, M.K., 1980, Physical illness manifesting as psychiatric disease,

Archives of General Psychiatry, 37, $989-995$

Hoffman, R.S. and Koran L.M., 1984, Detecting physical illness in patients with mental disorder, Psychosomatics, 25, 9, 654 - 660

Honig, A., Escher, A.D.M.A.C., Romme, M.A.J., Breuls, M.G.G.J., 1986, Miskend of ontkend probleemgebied; somatische aandoeningen bij ambulante chronische psychiatrische patiënten, (Undervalued or denied problem area, somatic dysfunctioning of chronic psychiatric patients living in the community), Tijdschrift voor Psychiatrie, 28, 676-686

Honig, A., Radstake, S., Romme, M.A.J., Breuls, M.G.G.J., 1988, Problem analysis: an instrument in the rehabilitation of chronic psychiatric patients in the community, International Journal of Social Psychiatry, 33, 303 - 311

Hoogduin, C.A.L., Haan, E. de, Terluin, B., 1985, Somatische aandoeningen bij opgenomen psychiatrische patiënten, (Somatic illness in psychiatric in-patients) Tijdschrift yoor psychiatrie, $27,105-114$

Kampmeier, M.H., 1977, Diagnosis and treatment of physical disease in the mentally ill, Annuils Internal Medicine $86,1977,637-645$

Keeney, B.P., 1983, Aesthetics of change, New York, Guildford Press,

Koranyi, E.K., 1979, Morbidity and rate of undiagnosed physical illnesses in a psychiatric clinic population, Archives of General Psychiatry, 36, 414-419

Maricle, R.A., Hoffman, W.F., Bloom, J.D., Faulkner, L.R.,

Keepers, G.A., 1987, The prevalence and significance of medical illness among chronically mentally ill outpatients, Community Mental Health Journal, 23, 2, 81-90

Patterson, C.W., 1978, Psychiatrists and physical examinations: a survey, American Journal of Psychiarry, 135, $967-968$

Ramsay, R.A., Krakowski, A.J., Rydzynski, Z., Jarosz, M.,

Engelsmann, F., Ananth, J., 1982a, International comparison of the prevalence of psychosomatic disorders in schizophrenic patients, Psychotherapy and Psychosomatics, $38,206-220$ 
Ramsay, R.A., Ananth, J., Engelsmann, F., Krakowshl, A.J,

Wittkower, E.D., Ghadirian, A.M., 1982 b, Schizophrenia and psyohosomatic illuess, Journal of Psychosomatic Research, 26, $33-42$

Ramsay, R.A. and Engelsmann, F., 1983, Epidemiology of psychosomatic disorders in schizophrenic patients: methodological issues, Psychotherapy and Psychosomatics, 40, $148-157$

Rigby, J.C. and Oswall, A.G., 1987, An evaluation of the performing and recording of physical examinations by psychiatric trainees, British Joumal of Psychiatry, $150,533-535$

Sandifer, M.G., 1977. The education of the psychiatrist as a physician, American Journal of Psychiatry, 134, 50-53

Sims, A., 1987, Why the excess mortality from psychiatric illness? British Medical Joumal. Dutch edition, $412 \mathrm{I}-412 \mathrm{II}$

Summers, W.K., Munoz, R.A., Read, M.R., 1981, The psychiatric physical examination - Part I: Methodology, Joumal of Clinical Psychiatry, 42, 95 - 98 
PHYSICAL HLLNESS IN CHRONIC PSYCHIATRIC PATIENTS FROM A COMMUNITY PSYCHIATRIC UNIT: THE IMPLICATIONS FOR DAILY PRACTICE

Lichamelijke ziekten in een ambulante praktijk voor chronische psychiatrische patiënten: behandelingsconsequenties

A. Honig, P. Pop, E.S. Tan, H. Philipsen, M.A.J. Romme

British Journal of Psychiatry, 155, 58-64, 1989

\section{SUMMARY}

The prevalence, significance of physical diseases, and health care-seeking behavior were examined in a sample of 218 chronic psychiatric patients from an urban community psychiatric unit. Only $14 \%$ declined a medical screening. Fifty-three percent of the respondents had one or more probable or certain physical diseases warranting further medical attention. The majority of the diseases found were minor and typical of primary care problems. A severe (i.e., life-threatening) disease, was present in $7 \%$ of the respondents. Eighty-seven percent of the patients visited their $\mathrm{GP}$ at least once a year. The implication is made that a frequent consultation with primary care specialists and health care-seeking behavior be noted and included in any evaluation of the medical needs of chronic patients in community psychiatric care. 


\section{INTRODUCTION}

Half of the patients in psychiatric care suffer from one or more physical illnesses, a quarter of which are thought to have causal relationships with the presenting psychiatric disease. The referring agent or therapist involved is, in the majority of these cases, unaware of the coexisting physical illness.

This is the alarming conclusion of virtually all researchers in the field (Koranyi, 1979; Hall et al., 1980; Hoffman \& Koran, 1984; Ananth, 1984) and these data are not limited to acute and chronic psychiatric inpatients. Data on chronic community psychiatric patients - the focus of this report - are quite similar (Barnes et al., 1983; Beresford et al., 1985).

If these research data are in fact accurate, one would have to conclude that physical disease poses a formidable problem, one that is often denied in daily community psychiatric practice. This, in turn, would mean that chronic community psychiatric patients are deprived of needed medical care and are prone to undetected and severe physical diseases.

Problems interpretating previous research data in relation to ambulatory care are discussed and incorporated in the present study. The findings of an investigation into the presence of physical disease, patients' medical health care-seeking behavior, and previously undiagnosed disease in chronic community psychiatric patients are also reported. Finally the clinical implications are discussed.

\section{PHYSICAL DISEASE AND RESEARCH}

\section{Definition problems in research}

Physical disease is a concept which is hard to define and often open to various interpretations. To quote Dubos, "The difficulty in defining disease is implicit in the very structure of the word itself (Dubos, 1968). This statement does not only refer to mental disease but also to medical disease (Clare, 1976).

In research is only seldom a definition of, or some criteria for, physical disease given. In cases where this effort has been made, a considerably lower percentage of physical disease is reported, on the average, 20\% less (Eastwood and Trevelyan, 1974; Hoogduin et al., 1985).

"Diseases" such as lipoma of the back, undescended testicle, hyperlipidemia, atrophy of 
one kidney, hyperostosis interna frontalis etc. (Hall et al, 1980; Maricle, 1987)

illustrate this definition problem. Terms such as "sickness", "ailment", "condition", "handicap", and "abnomal finding on further examination", are all used interchangeably and sometimes taken for disease.

The majority of diseases often go undiagnosed. The label "misdiagnosis" however, may not be applicable at all. For example, a general practitioner (GP)

could well be aware of a physicall disorder but, knowing the course of the disorder, not diagnose a disease (e.g., a serological scar from a previous syphilitic infection), while another therapist, not knowing the previous history, may diagnose a luetic infection on a one-time positive serology. A therapist may also apply another definition of physical disease, or a patient may refuse any physical screening procedure while in community psychiatric care. In the avallable literature, these possibilities are not accounted for but rather are regarded as misdiagnoses.

Unfortunately not all cues can be fully interpreted following a once only check-up. A detected high bloodpressure for instance with otherwise no abnormalities during the examination does not justify a diagnosis of uncomplicated hypertension. A follow-up is needed to confirm or exclude the suspected diagnosis.

Whether further medical treatment is necessary very much depends on the severity of the disease diagnosis. However, only Eastwood and Trevelyan (1972) and Kreitman et al. (1966) give a severity rating; certainty on the diagnosis is never given.

\section{Community psychiatry and medical care}

Community psychiatric care for the chronic patient does not, in general, provide for a protocolized evaluation of physical health. Many community psychiatric centers lack basic facilities and medical manpower for carrying out a routine physical check-up. This was also the case with the unit referred to in the present study.

Community psychiatry often operates in multidisciplinary teams. Within such a team, individual members tend to assume more responsibility for direct patient care and management than do their hospital counterparts. The responsibilities of community psychiatric nurses, psychologists, and social workers from such a team in the management of physical complaints and symptoms of their patients is not well defined (Davidson et al., 1988). 
Unlike inpatient psychiatry, there is, in community psychiatry a certain overlap with other directly accessible health care services, such as general practice. Clear responsibility for the physical health monitoring of chronic psychiatric patients cannot be clamed by any ambulatory service and is, in general, pragmatically left to the better judgment of the patients themselves. Whether chronic community psychiatric patients actually use the ambulatory medical resources available to them has not been determined. Adequate utilization of available resources can however, be of importance to their actual physical well-being.

\section{Chronic community psychiatric patients}

Stigmatizing remarks that are often made regarding chronic psychiatric patients are seldom systematically investigated and are sometimes given as an excuse to decide against a physical screening. Reasons mentioned in the literature include: deteriorated cognitive functions, psychological regression, and affective deterioration (Ramsay et al., 1982a; Ramsay and Engelsman, 1983); a prolonged psychiatric history (Ramsay et al., 1982b); and the impression chronic psychiatric patients tend to make on others, such as "malodorous", "dirty", "may not cooperate" (Kampmeier, 1977; Hoffman \& Koran, 1984), and "unattractive and poor" (Adller, 1972). In a recent study (Maricle et al., 1987), 43 out of 100 chronic community psychiatric patients indeed declined a medical screening. These presumptions need to be investigated further in orcler to be able to adapt services to these patients' traits and handicaps.

\section{METHOD}

In view of the abowe-mentioned definition problems, traits inherent to community psychiatry, and possible patient traits, a research project was set up to measure the prevalence of well-defined physical disease as well as functional illness. For research purposes, physical disease was defined as the manifestations for which a patient needs medical treatment and/or further medical investigations.

Each physical disease was rated according to severity, certainty of diagnosis, and duration of disease. A physical disease which was regarded as being liable to "threaten or shorten life" was placed in the category "severe" and all the others were placed in the category 
opinions on the presence of such a disease. The vasage of medical and mentall health care were also measured.

Using a 5-point scale, the screening specialist in internal medicine rated all patients on communicativeness during the interview, memory regarding medical and psychiatric history physical hygiene, and cooperation during the screening procedures. These data were then compared with those of a matched, newly admitted sample of patients to an intemal medicine outpatient clinic of an urban teaching hospital serving the same population.

All patients $(n=218)$ who, at that time, had been receiving treatment for at least one year in a CPU for chronic psychiatric patients at an urban community mental health service in Maastricht, the Netherlands, were asked to participate in the study.

After giving informed consent, each participating patient received an evaluation including an examination by the internal medicine specialist. This evaluation consisted of a brief, oral general medical history, focusing on past and current symptoms, plus a standardized physical examination as proposed by Summers et al. (1981).

Laboratory studies, incliding a 20-item automated chemistry panel (SMA-20), a complete blood count (CBC) with differential, an erythrocyte sedimentation rate, a serological test for syphilis (TPHA), thyroid stimulating hormone level (TSH), serum-free thyroxine, urineanalysis, and an electrocardiogram (ECG), were obtained for each patient. In addition, the CPU therapist was asked to supply both a medical diagnosis and a diagnosis according to DSM III, grouped in nine main categories, for all patients.

\section{RESULTS}

\section{Demographics}

Of the 218 patients, $156(72 \%)$ participated in the evaluation; in the other cases, the patient or the therapist or both actively or passively declined the medical evaluation over the 12 - month study period.

The average age of the participants was 45.5 years (range $=23$ to 62 years; mode $=42$ years). The group consisted of 56 men $(36 \%)$ and 100 women $(64 \%)$. The majority of men ( $43 \%$ ) were unmarried; $41 \%$ were married. Forty-five percent of the women were married; $30 \%$ were divorced. Most participants were currently living with their family or partner (44\%); $30 \%$ lived alone. Only $8 \%$ were currently employed. 
A psychotic disorder was diagnosed in 48 patients, and an affective disorder was diagnosed in 50. Twenty-four patients exhibited anxiety disorders and 53 personality disorders. Substance abuse disorders were found in 7 patients; organic mental disorders in 4, and 12 had some other DSM III diagnosis. In 6 patients, no certain diagnosis could be agreed upon. Thirty-three patients were also noted as having a borderline intellectual functioning (IQ = 74-84).

The average duration of the treatment to date was 4 years (range $=1-31$ years). The number of lifetime psychiatric hospitalizations, as documented in the medical record or specifically identified by the patient, was 1.7 ; the range was $0-33$. The number of admissions to a medical ward during the research year was 15. Sixteen patients were admitted to a psychiatric wand once or more during the research year. Eighty-nine patients (57\%) were currently being treated with psychotropic medication; $32(20.5 \%)$ received some type of antipsychotic medication, 22 an antidepressant, 14 a lithium preparation, and 46 received anxiolytic medication on a regular basis.

\section{Frequency of visits to a CPU therapist and GP}

In the year preceding the medical examination, the CPU therapists reported an average of 18 contacts with their male patients (range $=3-39$; median $=3$ ) and 25 with their female patients (range $=3-204$; median $=4$ ).

GPs were contacted, on the average, 4.5 times yearly by the male patients and 6.6 times yearly by the female patients. Sixteen percent of the male patients and $13 \%$ of the female patients did not attend the GP surgery at all during the research year. Nationwide, the frequency of GP visits for males is 2.9 and for females 4.1 per year (C.B.S., 1986).

\section{Prior medical history}

Forty-three patients (28\%) reported, prior to the study, having a known medical condition that was being treated either by their GP or a medical specialist. According to the CPU therapist, 51 patients (33\%) were known to have a physical disease. In 49 patients (31\%) the GP diagnosed a physical disease. Table 1 delineates the range of conditions. 
Table 1

Frequency of physical diseases using the international definition of printiry care (ICPC, 1985)

\begin{tabular}{|c|c|c|c|c|}
\hline PHYSICAL DISEAISE & Patient & $\begin{array}{l}\text { CPU } \\
\text { therapist }\end{array}$ & GP & $\begin{array}{l}\text { Specialist in } \\
\text { internal } \\
\text { medicine }\end{array}$ \\
\hline General and Unspecific & 2 & 3 & 2 & 10 \\
\hline Infectious diseases & 1 & 0 & 0 & 1 \\
\hline Multiple trauma & 0 & 1 & 0 & 1 \\
\hline Adverse effect medical & & & & \\
\hline agent proper use & 0 & 1 & 1 & 8 \\
\hline Other & 1 & 1 & 1. & 0 \\
\hline \multicolumn{5}{|l|}{ Blood, blood-forming organs, } \\
\hline Iymphatics, spleen & 1 & 1 & 1 & 0 \\
\hline Digestive system diseases & 5 & 7 & 6 & 15 \\
\hline Eye and ear diseases & 1 & 2 & 5 & 2 \\
\hline Circulatory system diseases & 12 & 17 & 17 & 32 \\
\hline \multicolumn{5}{|l|}{ Hypertension with secondary } \\
\hline complications & $\mathbb{1}$ & 0 & 2 & 2 \\
\hline Other & 5 & 10 & 7 & 15 \\
\hline Musculoskeletal diseases & 11 & 5 & 9 & 13 \\
\hline Osteoarthritis of spine & 4 & 0 & 2 & 0 \\
\hline Back pain with radiating symptoms & 1 & 1 & 1 & 5 \\
\hline \multicolumn{5}{|l|}{ Rheumatoid arthritis and allied } \\
\hline conditions & 3 & 2 & 1 & 0 \\
\hline Other & 3 & 2 & 6 & 8 \\
\hline Neurological diseases & 5 & 6 & 3 & 6 \\
\hline Migraine & 3 & 3 & 0 & 0 \\
\hline Other & 2 & 3 & 3 & 6 \\
\hline Respiratory diseases & 7 & 5 & 8 & 7 \\
\hline Chronic bronchitis/bronchiectasis & 6 & 5 & 7 & 7 \\
\hline Other & 1 & 0 & 1 & 0 \\
\hline Skin diseases & 1 & 6 & 6 & 3 \\
\hline \multicolumn{5}{|l|}{ Endocrine, metabolic and nutritional } \\
\hline diseases & 8 & 8 & 9 & 15 \\
\hline Morbid obesity & 0 & 1 & 2 & 3 \\
\hline Diabetes mellitus & 4 & 2 & 3 & 6 \\
\hline Hyperthyroidism & 2 & 1 & 1 & 1 \\
\hline Other & 2 & 4 & 3 & 5 \\
\hline Urinary system diseases & 4 & 5 & 3 & 6 \\
\hline Syphilis male/female & 0 & 1 & 2 & 2 \\
\hline Other diseases & 1 & 0 & 1 & 1 \\
\hline
\end{tabular}

Thirty-two patients $(20.5 \%)$ reported using a prescribed medication for non-psychiatric purposes; 24 (15\%) used prescribed medication for both medical and psychiatric purposes. For 65 patients (42\%), only psychotropic medication was prescribed. 


\section{Current CPU treatment}

The mean length of the current treatment was 4 years (range $=1-31$ years). Fifty-ight patients $(37 \%)$ were in treatment for $3-4$ years, and 35 patients $(22 \%)$ for $5-6$ years. Forty-three percent of the participants were, at the time, being treated by medically trained therapist (i.e. consultant psychiatrist, registrar in psychiatry, or community psychiatric nurse), meaning that over half of the population was not seeing a medically trained therapist on a regular basis.

\section{Physical complaints}

One hundred and thirty-seven patients (88\%) described at least one physical complaint on a self-report questionnaire which the patients completed prior to their medical examination.

According to the CPU therapist, 130 patients (83\%) described one or more physical complaints at the time of the examination. The GP noted one or more physical complaints in $120(77 \%)$ of the patients during their last visit in the research year.

One hundred and thirty patients ( $83 \%$ ) expressed one or more physical complaints when asked by the specialist in internal medicine. This number increased to 149 patients (96\%) during history-taking (Table 2).

Table 2

Physlcal complailints and diseases

\begin{tabular}{lcccc}
\hline & Patient & CPU therapist & GP & specialist in I.M. \\
& & & & \\
\hline Physical complaint & $88 \%$ & $83 \%$ & $77 \%$ & $83 \%$ \\
(one or more per patient) & $n=137$ & $n=130$ & $n=120$ & $n=129$ \\
\hline Physical disease & $28 \%$ & $33 \%$ & $31 \%$ & $53 \%$ \\
(one or more per patient) & $n=43$ & $n=51$ & $n=49$ & $n=82$ \\
\hline Severe physical disease & & $6 \%$ & $4 \%$ & $7 \%$ \\
(one or more per patient) & & $n=9$ & $n=6$ & $n=11$ \\
\hline
\end{tabular}


Physical examination findings provided new information on over half of the patients (Table 3). On 27 occasions, physical examination findings resulted in a diagnosis of physical disease. In 4 cases, suspicion of physical disease during history-taking was rejected following physical examination. These figures indicate the clinical medical importance of a routine physical examination.

Table 3

\begin{tabular}{ll}
\hline Physical examination findings \\
\hline Finding & Number \\
Elevated blood pressure & 14 \\
Weight - 10\% high limit & 20 \\
Any P.E. Low limit & 4 \\
Any neurological (excl. neurological) & 56 \\
No conformation of abnormality as & 8 \\
suspected following history-taking & 4 \\
No abnormal finding & 73 \\
\hline
\end{tabular}

Laboratory abnormalities judged by the specialist in internal medicine as aspecific and not warranting further evaluation were present in 108 patients (69\%). Due to laboratory testing a diagnosis was established on 28 occasions. As a result of the laboratory test information on one patient, a previously suspected disease was rejected.

\section{Physical disease}

Forty-three patients reported having some physical disease; according to the CPU therapist and GP, the number of patients with one or more physical diseases was 51 (33\%) and $49(31 \%$ ), respectively (Table 2). Physical diseases were diagnosed by the specialist in internal medicine based on findings in the sequence history-taking, physical examination, and a fixed set of laboratory studies on each patient.

The specialist in internal medicine diagnosed physical disease in 82 patients (53\%); on all diagnoses, complete agreement was reached by both the specialist and the research managing CPU psychiatrist (A. Honig). Table 4 delineates the 63 newly diagnosed physical diseases. 


\section{Table 4}

Newly diagnosed physical diseases

\begin{tabular}{|c|c|c|}
\hline Disease & $\begin{array}{l}\text { Number } \\
\text { of cases }\end{array}$ & Disease \\
\hline
\end{tabular}

Adv. effect of medical agent

proper use

Infectious disease

Hiates (diaph.) hernia

Cirrhosis/other liver disease

Other disease digestive system

Diseases of the eve

Chronical ischemic heart disease

Chronic bronchitis

Atopic dermatitis

Uncomplicated hypertension

Other diseases circulatory system

Morbid obesity

Diabetes mellitus

Other endocrinological

metabolic and nutritional diseases
Back pain with

radiating sympt.

Traumatic arthritis/

arthropathy

3

1

3

4

4

Other disease musculo-

skeletal system

Disease of neurological

system

Elevated blood

pressure

Cystitis/other urinary

infections, non veneral 4

Uterovaginal prolaps 1

Other disease urinary

system

The specialist in internal medicine diagnosed, in all, 112 physical diseases. Circulatory diseases were most frequently found, followed by endocrine and metabolic diseases (Table 1). On 53 (47\%) of the diseases, an approximate duration could be given. Nine diseases (17\%) lasted less than 1 year, $10(18.9 \%)$ lasted between 1 and 3 years, and 34 (64.1\%) lasted longer than 3 years.

Applying the earlier definition of severity, the specialist in internal medicine rated 13 physical diseases in 1.1 patients (7\%) as "severe" and 87 as "not severe". For 8 diseases, no definite conclusion could be given as to the severity.

Fifty-six diseases (50\%) were rated as "certainly present". Thirteen diseases were rated both "severe" and "certainly present"; seven of these were circulatory diseases, three were endocrine and three were other diseases.

Of the 63 newly diagnosed physical diseases, only three were rated "severe"; in five cases, no severity indication could be given. Twenty-five of the newly diagnosed diseases were rated "certainly present". 


\section{Agrement on the presence of a physical disease}

In 55 patients $(35 \%)$, all four participants agreed on the absence of one or more defined physical diseases. In the other patients $(65 \%)$, at least one of the participants described one or more physical diseases.

The factual agreement on the absence or presence of one or more defined physical diserases per patient between the specialist in internal medicine and the CPU therapist, GP, and patient was moderate (Table 5), with Cohen's kappa not exceeding 0.35 .

Table 5

\section{Agreement on the presence of one or more diseases per patient}

\begin{tabular}{lrrr}
\hline $\begin{array}{l}\text { Specialist in } \\
\text { internal medicine }\end{array}$ & $\begin{array}{l}\text { GP } \\
\text { Disease }\end{array}$ & No disease & Total number \\
& & & \\
\hline Disease & 40 & 42 & 82 \\
No disease & 9 & 65 & 74 \\
\hline Total number & 49 & 107 & 156 \\
\hline
\end{tabular}

Kappa $\approx 0.35$

\begin{tabular}{llrr}
\hline $\begin{array}{l}\text { Special ist in } \\
\text { internal medicine }\end{array}$ & $\begin{array}{l}\text { CPU } \\
\text { Disease }\end{array}$ & No disease & Total number \\
& & & \\
\hline Disease & 41 & 41 & 82 \\
No disease & 10 & 64 & 74 \\
\hline Total number & 51 & 105 & 156 \\
\hline
\end{tabular}

$\mathrm{Kapp} a=0.35$

\begin{tabular}{lrrr}
\hline $\begin{array}{l}\text { Specialist in } \\
\text { internal medicine }\end{array}$ & $\begin{array}{l}\text { Patient } \\
\text { Disease }\end{array}$ & No disease & Total number \\
& & & \\
\hline disease & 36 & 46 & 82 \\
No disease & 7 & 67 & 74 \\
\hline Total number & 43 & 113 & 156 \\
\hline
\end{tabular}

Kappa $=0.33$

On the presence or absence of one or more severe, certainly present physical diseases, as diagnosed by the specialist in internal medicine, agreement was even less with the GP and CPU therapist (Table 6). For clinical reasons, no severity ratings were asked of the patient himself. 
Table 6

Agreement on the presence of one or more severe and certaln diseases per patient

\begin{tabular}{|c|c|c|c|}
\hline $\begin{array}{l}\text { Specialist in } \\
\text { internal medicine }\end{array}$ & $\begin{array}{l}\text { GP } \\
S+C \text { disease }\end{array}$ & Non $\mathrm{S}+\mathrm{C}$ disease & Total number \\
\hline $\mathrm{S}+\mathrm{C}$ disease & 3 & 8 & 11 \\
\hline Non $S+C$ disease & 3 & 142 & 145 \\
\hline Total number & 6 & 150 & 156 \\
\hline
\end{tabular}

Kappa $=0.29$

\begin{tabular}{llrr}
\hline $\begin{array}{l}\text { Specialist in } \\
\text { internal medicine }\end{array}$ & CPU & & \\
& & & \\
& & & \\
\hline S+C disease & 3 & 8 & 11 \\
Non $S+C$ disease & 6 & 139 & 145 \\
\hline Total number & 9 & 147 & 156 \\
\hline
\end{tabular}

Kappa $=0.22$

$\mathrm{S}+\mathrm{C}=$ severe and certainly present

Of the 13 severe and certain physical diseases, diagnosed by the specialist in internal medicine, $9(70 \%)$ were known to the GP and CPU together, although they were not always rated as severe and certainly present.

\section{Functional illness}

Physical complaints for which no organic abnormal functioning could be detected were rated "aspecific"; of the three main physical complaints, one or more aspecific physical complaints was present in 136 patients ( $87 \%$ ). One hundred and fourteen patients ( $73 \%$ ) were diagnosed by the specialist in internal medicine as having one or more functional illnesses, ranging from irritable bowel syndrome to tension headache. By comparison, in only 47 patients (20\%) were physical complaints for which an organic cause could be detected present. 


\section{Non-respondents}

Sixty-two patients (28\%) did not participate in the project. Of the whole research population only 30 patients (14\%) declined the medical evaluation. For half of the group of non-respondents, the CPU therapist advised against an evaluation for one reason or another. In 13 cases, there was either no contact with the patient or the patient could not be traced (no fixed residence). The CPU therapist collected the same demographic and diagnostic data from both the respondents and non-respondents. There were no statistical differences in demographic data. As for diagnosis according to the DSM III, personality disorder, substance abuse, and psycho-organic disorders were over-represented in the latter group.

The CPU therapist noted considerably fewer physical complaints in the non-respondent group: $52 \%$ as compared with $82 \%$ in the respondent group. The number of physical diseases was equal in both groups.

\section{Patients' behavior}

In the present study only 30 patients (14\%) refused to cooperate in the project. The ratings on a 5-point scale by the specialist in internal medicine on communicativeness, ability to recall medical and psychiatric history, physical hygiene, degree and quality of activity, cooperation and global impression were compared with those of 60 matched, new patients attending an internal medicine outpatient clinic. The ratings on all of these items showed no significant differences.

\section{DISCUSSION}

Somatic complaints and symptoms were almost invariably present in this sample of chronic community psychiatric patients. Almost three-quarters of the patients were diagnosed as having a functional disorder; nearly half of the patients were medically ill, but hardly any severe physical diseases were found. The bulk of the physical diseases that were detected could easily be dealt with by the GP.

Although the results of a longer term follow-up is still in progress, it seems that medical treatment of the diagnosed diseases does not change the chronic psychiatric problems 
dramatically. Certainly no mimicks (i.e. organic conditions erroneously taken for psychiatric diseases) were found. Our data confirm Maricle's indings (1987) in a similar setting with a smaller and diagnostically less diverse sample of chronic community psychiatric patients than ours. It seems safe to say that, at least in our local health care system, no medical attention is witheld from our sample of chronic community psychiatric patients. More specifically, our group of chronic community psychiatric patients is, in general, very capable of making use of available ambulatory health care services. During a physical screening procedure, they do not significantly differ in behavior from a non-psychiatric ambulatory population, and they are, in the majority of cases, prepared to cooperate in a 2 -hour physical screening procedure.

Agreement on the part of all participants regarding the physical health of this patient population is scarce. This does not, as such, mean a high percentage of "misdiagnosing", but could be interpreted as a trait inherent to the interaction between the patient and the specific health care therapist (GP, CPU therapist, or specialist in internal medicine).

Somewhat alarming however, was the high percentage of newly diagnosed diseases induced by psychotropic medication. More than half of the patients $(57 \%)$ used some prescribed psychotropic medication. Fourteen of these patients were taking Lithium carbonate at the time of the study. Of these 14 patients, 6 were diagnosed by the specialist in internal medicine as suffering adverse effects of this medication. Five of these patients were possibly mildly hypothyroid. This was, in all five cases, unknown to the prescribing CPU therapist. Evaluation of laboratory thyroid functioning is very likely hampered by the absence of direct access to laboratory facilities in Dutch community psychiatric units.

Perhaps the most important finding to come out of this study is the need for close cooperation between the GP and CPU therapist. This is true, in the first place, in order to distinguish those patients who do not make adequate use of health care services and who thereby form a potential medical risk. Secondly, when working together, GP and CPU therapist can more adequately screen and diagnose severe physical diseases, $70 \%$ of the diseases that the specialist in internal medicine rates as "severe" and "certainly present". This cooperation with the GP could well be executed by a CPU therapist of any discipline. This consultation could result in a referral to a CPU psychiatrist or to a GP for further evaluation. Whenever a physical screening is carried out history-taking and the performance of a routine, standardized physical examination (Summers et al., 1981) seem to be most valuable in the entire diagnostic procedure. 
Somatic fixation or denial, on the part of both CPU therapist and patient, could be prevented by the above recommended physical screening procedures.

\section{REFERENCES}

Adler, $\mathbf{G}_{*}, 1972$, Helplessness in the helpers, British Joumal of Psychology, 45, 315326

Ananth, J., 1984, Physical Ilness and Psychiatric Disorders, Comprehensive Psychiatry, 25, 586-593

Barnes, F.B., Mason, J.C., Greer, C., Ray, F.T., 1983, Medical illness in chronic psychiatric out-patients, General Hospital Psychiatry, 5, 191-195

Beresford, T.P., Hall, R.C.W., Wilson, F.C., Blow, F., 1985, Clinical laboratory data in psychiatric out-patients, Psychosomatics, 26, 9, 731-744

Clare, A., 1976, Pswchiatry in dissent, Trawistock Publications London

Davidson, R.E., Factor, R., Grundlack, E., Adler, K., 1988, Psychiatric nursing roles in a community mental health center, Community Mental Health Journal, 24, 83-86

Dubos, R., 1968, Man, medicine and environment, Pall Mall Press London

Eastwood, M.R. \& Trevelyan, M.H., 1972, Relationship between physical and psychiatric disorder, Psychological Medicine, 2, 363-372

Hall, R.C.W., Gardner, E.R., Stickney, S.K., LeCann, A.F., Popkin, M.K., 1980, Physical illness manifesting as psychiatric disease, Archives of General Psychiatry, 37, 989-995

Hoffman, R.S. \& Koran, L.M., 1984, Detecting physical illness in patients with mental disorder, Psychosomatics, 25, 9, 654-660

Hoogduin, C.A.L., Haan, E. de, Terluin, B., 1985, Somatische aandoeningen bij opgenomen psychiatrische patiënten, (Somatic illness in psychiatric in-patients), Tijdschrift voor psychiatrie, $27,105-114$

Kampmeier, M.H., 1977, Diagnosis and treatment of physical disease in the mentally ill, Annals Internal Medicine, 86, 637-645

Koranyi, E.K., 1979, Morbidity and rate of undiagnosed physical illnesses in a psychiatric clinic population, Archives of General Psychiatry, 36, 414-419

Kreitman, N., Pearce, K.I., Ryle, A., 1966* The relationship of psychiatric, psychosomatic and organic illness in a general practice, British Journal of Psychiatry, $112,569-579$

Maricle, R.A., Hoffman, W.F., Bloom, J.D., Faulkner, L.R., Keepers, G.A., 1987, The prevalence and significance of medical illness among chronically mentally ill out-patients, Community Mental Health Journal. 23, 2, 81-90

Ramsay, R.A., Krakowski, A.J., Rydzynski, Z., Jarosz, M., Engelsmann, F., Ananth, J., 1982a, International comparison of the prevalence of psychosomatic disorders in schizophrenic patients, Psychotherapy and Psychosomatics, $38,206-220$

Ramsay, R.A., Ananth, J., Engelsmann, F., Krakwoski, A.J., Wittkower, E.D., Ghadirian, A.M., 1982b, Schizophrenia and psychosomatic illness, Journal of Psychosomatic Research, 26, 33-42

Ramsay, R.A. \& Engelsmann, F., 1983, Epidemiology of psychosomatic disorders in schizophrenic patients: methodological issues, Psychotherapy and Psychosomatics, $40,148-157$

Summers, W.K., Munoz, R.A., Read, M.R., 1981, The psychiatric physical examination - Part I: Methodology, Joumal of Clinical Psychiatry, 42, $95-98$ 


\title{
DETECTING PHYSICAL DISEASE BY QUESTIONNAIRE IN CHRONIC COMMUNITY PSYCHIATRIC PATIENTS
}

Herkenning van lichamelijke ziekten bij ambulante chronische psychiatrische patiënten met behulp van een klachtenlijst

\author{
A. Honig, E.S. Tan, A. Weenink, P. Pop, H. Philipsen \\ Hospital and Community Psychiatry (in press)
}

\section{SUMMARY}

Somatic screening procedures in community psychiatry, especially for chronic patients, is only in its infancy. Many community psychiatric centers still lack sufficient facilities and medical manpower to carry out a routine physical screening. Most patients only have access to a psychiatrist via non-medical personnel or a community psychiatric nurse at best.

Surveys show that, on the average, haif of the patients under psychiatric care suffer from a physical disease. The vast majority of psychiatric patients have somatic complaints. In community psychiatry there is a clear need for an instrument that is able to screen physical disease and that can be used by non-medical personnel .

The Hopkins Symptom Checklist (HSCL), a self report scoring list for physical symptoms, was tested as such an instrument in 156 chronic community psychiatric patients who were screened for physical disease. Demographic, social, and psychological traits affecting the HSCL scores were analyzed. The HSCL was not able to discriminate physical disease in this population. Physical complaints in this patientgroup are nearly always present but do not seem to refer specifically to physical disease. 


\section{INTRODUCTION}

With the increasing popularity of community psychiatric care of chronic patients, management problems in the organization of care have arisen and been discussed (1). One of these organizational problems, the focus of this article is the monitoring of physical health.

Community psychiatry, unlike clinical inpatient psychiatry, has no routine protocol for the screening of physical disease. Continuity of care, regular and easy access to care are essential, and so the day-to- day management of these patients is most often carried out by therapists other than psychiatrists. Thus, the only access many chronic community psychiatric patients have to a psychiatrist is via their community psychiatric nurse, social worker, or psychologist.

Physical disease is an important issue. Half of the patients under psychiatric care suffer from a physical disease; in $25 \%$ of these cases, this physical disease is thought to have a causal or contributory relationship to the presenting psychiatric disease. The referring agent or therapist involved is, in the majority of these cases, unaware of coexisting physical illness. This is the alarming conclusion of virtually all researchers in the field (25).

More recent research in the United States (6) has confirmed the presence of physical. disease in half of a chronic ambulatory population, but has noted at the same time that the bulk of the diseases were minor and could easily be dealt with by a general practitioner (GP) These findings have been replicated in the very same population we are now reporting on (7).

Although these two studies have put physical disease somewhat more into perspective, they support the need for a simple screening instrument in the monitoring of physical disease. This should be an instrument that can also be applied and interpreted by non medical personnel. An obvious choice for such an instrument is a physical complaint questionnaire.

The 58-item version of the Hopkins Symptom Check List (HSCL), was chosen for the purpose of our physical screening; HSCL-scores were related to the presence of physical disease as diagnosed by a specialist in internal medicine, who was not otherwise involved in the community psychiatric unit (CPU), and as diagnosed bij the patients' own GP. 


\section{THE HSCL}

This self-report scoring list measures physical discomfort and bas a state rather than trat character (8). The HSCL was selected because of its reliability (internal and test-retest consistency), its extensive use as monitoring instrument, and the avallability of a validated Dutch version of it (9).

The value of the HSCL as a diagnostic instrument is apparent from its ability to discriminate between various patient populations, and between patients and non-patients, from consensus with clinical judgment on the increase in pathology, and from its sensitivity in the measurement of change in psychophamacotherapy and psychotherapy (9).

The validation and evaluation of the Dutch version of the HSCL has only partly confirmed these promising results (9). While somatization, obsessive-compulsiveness, interpersonal sensitivity, depression, and anxiety are the five most distinguishable dimensions of the HSCL (8), the Dutch validated version only discriminates two scales, namely those involving psychiatric and somatic complaints. The reliability of these scales, in comparison with scales from the original version, is similar and satisfactory (9).

\section{METHOD}

From November 1986 until November 1987, all patients with a prolonged psychiatric history and psychosocial dysfunctioning in addition to their chronic psychiatric disease, who had been under continuous treatment for at least one year at our community CPU were asked to participate in a routine physical screening.

Of a total of 218 potential patients, $156(72 \%)$ participated in the screening, 56 men (36\%) and 100 women (64\%). Their average age was 45.5 years (range: $23-62$ years; mode: 42 years). The main diagnostic categories were: psychotic disorder in 48 patients, affective disorder in 50 , anxiety disorders in 24 patients and in 53 patients a personality disorder. Thirty-three patients $(21 \%)$ were also known to have only bordlerline intelligence (IQ 74-84); 89 patients ( $57 \%$ ) were being treated with psychotropic medication at the time the screening was done. The average duration of psychiatric treatment to date was 4 years (range: $1-31$ years). Of the 62 non-participating patients 30 declined the medical evaluation themselves; 13 could not be traced (no fixed residence); for half of the group non-participants, the CPU therapist advised against an evaluation for one reason or another.

A comparison of respondents and the whole population showed no statistically significant differences in demographic data. As for the DSM-III diagnosis, personality disorder, substance abuse, and psycho-organic disorders were overrepresented in the nonresponents. The number of patients with a physical disease, as diagnosed by the CPU therapist, was equal $(33 \%)$ in both groups.

According to the National Health Service in The Netherlands all patients are entitled to primary medical care as provided by a GP. This enabled us to seek the medical opinions of a number of GPs on our patients' physical health. A routine physical screening of all participating patients by a specialist in internal medicine served as a second medical opinion. 
The routine physucal check-up was perfomed at an outpatient clinic of the local university hospital (Acaderisich Ziekenhuis Maastricht) by one and the same specialist in intemal medicine. The physical screening consisted of a brief interview regarding past and current history and symptoms, a standardized physical examination (10), a standard battery of Jaboratory blood and urine tests, and an electrocardiogram (ECG). Following this routine procedure, the specialist determined the presence or absence of a physical disease.

The opinions of the patients GP and the CPU therapists were obtained by means of a questionatre. All observers used the same definition of physical disease, which was defined as those mamifestations for which a patient needs medical treatment and/or further medical investigation.

The $\mathrm{HSCL}$ was completed either prior vo or after the physical check-up depending on when the patient seemed at ease, and often as a way of minimizing waiting time during the screening procedure.

\section{RESULTS}

According to the CPU therapists, GPs, and specialist the number of patients with one or more physical diseases was 51,49 and 82 respectively. The degree of agreement between GP, specialist and CPU therapists on the presence of one or more severe and certain diseases was moderate with Cohen's Kappa not exceeding 0.35 .

The scores on the total-, psychiatric- and somatic scales did not differ significantly from the scores of a reference group of psychiatric patients (9).

The sensitivity and specificity of the scales with respect to the presence or absence of physical disease were low. A cut-off point of 7 or more on the somatic scale resulted in $a$ predictive value of $50 \%$ on the presence of a physical disease according to the specialist and of $33 \%$ according to the GP (see also table 1). Any change in this cut-off point did not improve the a posteriori chance with respect to the prior chance. 
Table 1 Somatic scalle scores on patlents diagnosed on the presence of physical disease by GP and speciallist

\begin{tabular}{|c|c|c|c|c|c|c|c|c|}
\hline & \multicolumn{4}{|c|}{+8} & \multirow{2}{*}{\multicolumn{2}{|c|}{ agreement }} & \multirow{2}{*}{\multicolumn{2}{|c|}{$\begin{array}{l}\text { disagreement } \\
\text { specialist specialist }\end{array}$}} \\
\hline & \multicolumn{2}{|c|}{ specialist } & \multicolumn{2}{|c|}{$\Phi$} & & & & \\
\hline somatic score: & N.D & $\mathrm{D}$ & N.D. & $\mathbb{D}$ & $\mathrm{N}: \mathrm{D}$. & $\mathrm{D}$ & N.D. & 0 \\
\hline low $(0-1)$ & 16 & 15 & 25 & 6 & 14 & 4 & 2 & 11 \\
\hline below average $(2-4)$ & 10 & 14 & 14 & 10 & 10 & 10 & $\therefore$ & 4 \\
\hline average $(5-8)$ & 25 & 22 & 28 & 16 & 22 & 13 & 3 & 9 \\
\hline above average $(9-10)$ & 7 & 12 & 12 & 6 & 5 & 4 & 2 & 8 \\
\hline high $(11-14)$ & 11 & 10 & 13 & 7 & 10 & 6 & 1 & 4 \\
\hline extremely high $(>14)$ & 5 & 9 & 10 & 4 & 5 & 4 & $-\infty$ & 5 \\
\hline mean & 3.6 & 3.2 & 3.8 & 2.5 & 3.8 & 2.5 & 2.8 & 37 \\
\hline S.D. & 4.7 & 4.4 & 4.7 & 4.1 & 4.8 & 4.1 & 4.5 & 4.5 \\
\hline
\end{tabular}
N.D. $=$ no disease
D. = disease

A sensitivity analysis using the numerical values did not change the sensitivity based on dichotomized values, not even when demographic, psychological, and social trats were taken into account.

The HSCL did not discriminate between those patients diagnosed by both specialist and GP as having a physical disease and others.

Multiple regression analysis on demographic, psychological and social traits which have been reported to influence physical health and, thereby, possibly the scoring on the HSCL, accounted for only $36 \%$ of the variance. Gender, psychotic state, taking psychotropic medication, educational level and age did affect the scoring.

\section{CONCLUSIONS}

The HSCL was not able to discriminate physical disease in this population. Physical complaints in this sample were nearly always present but do not seem to refer specifically to physical disease.

The sensitivity and specificity of the HSCL were low. The predictive value of the HSCL. scales is not more than chance. These results lead us to conclude that the HSCL, did not discriminate physical disease in this relatively small patient population and that it cannot be recommended as a screening instrument in the monitoring of the physical health of chronic community psychiatric patients. The HSCL in our sample did discriminate 
subgroups: psychotic patients scored slightly lower, higher educated patients scored lower than lower educated patients and scores increased with age.

Perhaps the fact that this questionnaire "invites" patients to complain, while they have persistent and multiple complaints of varying origin, is the very reason for the absence of a relationship between the HSCL and physical disease. In other words, the complaint behavior of this population is unpredictable and not specific with respect to physical disease. One will need to examine parameters other than patients' physical complaints in order to determine whether or not physical disease is present in this population.

\section{REFERENCES}

1. Bachrach LL: Defining chronic mental illness: a concept paper. Hospital and Community Psychiatry 39: 383-388, 1988

2. Koranyi EK: Morbidity and rate of undiagnosed physical illness in a psychiatric clinic population. Archives of General Psychiarry 36: 414-419, 1979

3. Hall RCW, Gardner ER, Stickney SK, et al: Physical illness manifesting as psychiatric disease. Archives of General Psychiatry 37: 989-995, 1980

4. Hoffman RS, Koran LM: Detecting physical illness in patients with mental disorders. Psychosomatics 25: 654-660, 1984

5. Ananth J: Physical illness and psychiatric disorders. Comprehensive Psychiatry 25: 586-593, 1984

6. Maricle RA, Hoffman WF, Bloom JD, et al: The prevalence and significance of medical illness among chronically mentally ill outpatients. Community Mental Health Journal 23: 81-90, 1987

7. Honig A, Pop P, Tan ES, et al: Physical illness in chronic psychiatric patients from a community psychiatric unit: the implications for daily practice. British Journal of Psychiatry 155: 58-64, 1989

8. Derogatis LR, Lipman RS, Rickels K, et al: The Hopkins Symptom Checklist, A self-report symptom inventory. Behavioral Sciences 19: 1-15, 1974

9. Luteijn F, Hamel LF, Bouwman TK, Kok AR: HSCL The Hopkins Symptom Checklist Manual, Lisse, Swets \& Zeitlinger, 1984

10. Summers WK, Munoz RA, Read MR: The psychiatric physical examination. Part I: methodology. Journal of clinical psychiatry 42: 95-98, 1981 


\title{
THE INFLUENCE OF CONSENSUS ON THE ASSESSMENT OF PHYSICAL DISEASE IN CHRONIC COMMUNITY PSYCHIATRIC PATIENTS
}

De waarde van overeenstemming in het herkennen van lichamelijke ziekten bij ambulante chronische psychiatrische patiënten

\author{
A. Honig, E.S. Tan, P. Pop, H. Philipsen, R. de Wit, P. van Pelt \\ Psychotherapy and Psychosomatics, in press
}

\section{ABSTRACT}

Physical disease is a frequent concomitant of mental disease. The majority of chronic psychiatric patients have physical complaints. Screening physical disease on a regular basis in an ambulatory setting for chronic psychiatric patients is often impossible if only for lack of medical manpower and facilities. Especially for the non-medical personnel of a community psychiatric unit (CPU) for chronic patients, approaching and handling physical complaints and diseases poses a formidable problem.

This paper addresses the issue of screening physical disease from a completely different viewpoint than that of the often advocated but just as often infeasible rontine physical examination and laboratory work-up. It is argued that consensus (i.e., agreement and mutual understanding) between patient and therapist on the physical well-being of the patient may increase the accuracy with which a CPU therapist, irrespective of his/her discipline assesses physical disease. This hypothesis was tested in a sample of 156 chronic ambulatory psychiatric patients. Consensus between patient and CPU therapist was measured by means of a questionnaire. The CPU therapist assessment on physical disease in both the consensus and no consensus group was compared with those of two external medical observers: the patients GP and a specialist in internal medicine, who followed a protocolized physical screening procedure.

The results tend to support the proposed hypothesis. Replication of this study using a larger sample is recommended in order to confirm the value of consensus in the assessment of physical disease in at least some subgroups of chronic ambulatory psychiatric patients and for the implications that consensus could have for daily community psychiatric practice. 


\section{INTRODUCTION}

The concurrence of physical and mental disease is a well-known phenomenon $(12,15)$. Less well known is the high finding of $30 \%-50 \%$ physical disease in chronic community psychiatric patients $(2,7,10)$.

A practical problem in the screening of physical disease is the multidisciplinary team approach used in community psychiatry. Within such a team, individual members assume more responsibility for direct patient care and management than their clinical counterparts. Physical examinations are performed only when indicated, and not as a routine procedure. A lack of medical manpower and -facilities often hampers such a procedure. As a result, a community psychiatric nurse, social worker or psychologist of a community psychiatric unit (CPU) normally has to first perceive signals of somatic dysfunctioning and then decide whether or not to consult the CPU psychiatrist or the patient's general practitioner (GP). Just how these community psychiatric workers should handle the physical complaints and symptoms of their patients remains an open and relevant question, as nearly all patients have physical complaints $(7,10)$.

Research in this area stops with the advise of a regular and protocolized physical screening which for various reasons, has not been implemented. Some states in the U.S. have even taken legal measures to make routine physical examinations mandatory.

In this article we report on a new, interpersonal approach to helping community psychiatric therapists, irrespective of their discipline, screen physical disease more adequately.

We started off with the notion that a therapeutic alliance between patient and therapist is a basic qualitative element of any successful therapeutic relationship. A therapeutic alliance is independent of the form of therapy offered to the patient and can be defined, on the one hand, as a non-neurotic, rational, reasonable relationship that enables both patient and therapist to cooperate and, on the other hand, as a relationship built on mutual respect, agreement, and understanding (6). The importance of a therapeutic alliance thas been stressed by various authors from various psychotherapeutic origins $(5,8)$.

A therapeutic alliance proves to be a significant and powerful predictor of psycho-therapy outcome (3). In order to be able to cooperate, the patient and therapist need a certain degree of mutual understanding or consensus, with respect to the problem(s) the patient is faced with. 
If one adopts the holistic view which stresses that man in health and disease functions as a psychosomatic unit (WHO Expert Committee on Psychosomatic Disorders, 1964), one could therefore argue that the effect of consensus also extends to physical processes. Therefore one could argue that consensus between patient and therapist has a favorable effect on the assessment of physical disease.

On this presumption we have formulated and tested the hypothesis that the assessment of physical disease in chronic ambulatory psychiatric patients changes in the direction of that of an external medical observer when patient and CPU therapist have consensus on the physical well-being of the patient. If this hypothesis would prove to be correct, it would not imply a direct relationship between consensus and an adequate physical assessment. It would however certainly justify more research in this area in order to prove such a direct relationship. This would have practical consequences, as CPU therapists whould then have to invest more time and energy into reaching consensus on the physical well-being of their patients in order to be able to assess their patients" physical condition more accurately.

\section{CONSENSUS}

Many models and definitions of consensus have been applied in the past. Our purpose was to find an operational concept that would be indicative of the quality of a patienttherapist relationship. Our concept of consensus is derived from the sociological model of consensus, one that is interactional rather than individual in character and that describes different levels of consensus (1.2).

Within the sociological model, consensus is linked to the degree of coordination or coorientation between members of a group (i.e., patient and therapist). Various levels of coorientation can be discriminated and operationalized (9). Agreement has been called the first level of co-orientation and it is defined as the degree of consensus with respect to a statement $X$.

Let us take, for example, the following statement: "This patient is physically healthy". If the patient and therapist agree with this statement independently, they are in agreement.

A second level of co-orientation is understanding. The question that is asked is how the other person would respond to the statement. If the therapist says that the patient will agree, and in fact the patient does agree, the therapist understands the patient.

Although higher levels of co-orientation have been operationalized, the questions involved are complex and could easily produce unreliable responses. 
The definition of consensus applied in this paper is the degree to which participants (mostly patient-therapist dyads) agree on a certain topic (i.e., the physical condition of the patient) and, at the same time, have a perception of the opinion of the other participant similar to the opinion of that other participant. This concept of consensus, consisting of the first two levels of coordination (agreement and mutual understanding) has been operationalized in a 22-statement questionnaire on physical well-being. Figure 1 shows some sample statements.

Figure 1: Some sample statements from the consensus questionnaire.

\section{Patient version}

\begin{tabular}{|c|c|c|}
\hline Statement & My opinion & $\begin{array}{l}\text { How I think } \\
\text { my therapist } \\
\text { will answer } \\
\text { this question }\end{array}$ \\
\hline I am physically healthy & 123 & 123 \\
\hline $\begin{array}{l}\text { My physical complaint(s) is/are troubling } \\
\text { me. }\end{array}$ & 123 & 123 \\
\hline
\end{tabular}

Therapist version

\begin{tabular}{|c|c|c|}
\hline Statement & My opinion & $\begin{array}{l}\text { How I think } \\
\text { my patient } \\
\text { will answer } \\
\text { this } \\
\text { question. }\end{array}$ \\
\hline This patient is physically healthy & 123 & 123 \\
\hline $\begin{array}{l}\text { This patient is troubled by his/her } \\
\text { physical complaint(s). }\end{array}$ & 123 & 123 \\
\hline
\end{tabular}

Key: $\quad 1$ = agreement

$2=$ no opinion/neither agreement nor disagreement

$3=$ disagreement 


\section{METHOD}

\section{Materiall}

From November 1986 untill November 1987, all of the patients who had been attending a CPU of an urban community psychiatric service (RIAGG Maastricht) continuously for one year or more were asked to participate in a routine physical screening by a specialist in internal medicine who was not otherwise affiliated with the CPU.

Only patients with a prolonged psychiatric history and psychosocial dysfunctioning, in addition to their chronic psychiatric disease are admitted to this unit.

Both patient and therapist were asked separately to complete their version of the consensus questionnaire.

That of the CPU therapist was completed at the time the patient was referred for screening.

The patient completed his/her version either prior to or after the physical check-up, depending on when the patient seemed at ease, and often as a way of minimizing waiting time during the screening procedure.

All observers applied the same definition of physical disease, namely those manifestations for which a patient needs medical treatment and/or further medical investigation. This definition was chosen to exclude physical handicaps and medical conditions of no direct medical consequence.

Because the National Health Service of The Netherlands claims that all inhabitants are entitled to primary medical care as provided by a GP, the patients' GP was the first person who, by means of a questionnaire, was aksed to give an opinion as to the presence of physical disease.

A specialist in internal medicine was the second to give a medical opinion, this by means of a routine physical screening of all participating patients. This screening consisted of:

1. a brief interview regarding past and current history and symptoms,

2. a standardized physical examination (13),

3. a fixed set of laboratory studies, including a 20-item automated chemistry panel (SMA-20), a complete blood count (CBC) with differential, an erythrocyte sedimentation rate, a serological test for syphilis (TPHA), a thyroid stimulating hormone level (TSH), a serum-free thyroxine, a urine analysis and an electrocardiogram (ECG). Following this routine procedure, the specialist in internal medicine decided on the presence or absence of physical disease. The routine physical check-up was performed in an outpatient clinic of the local university hospital. (Academisch Ziekenhuis Maastricht) by one and the same experienced specialist in internal medicine.

\section{Statistical analysis}

The 22 questions of the consensus questionnaire were submitted to factor analysis. Factor analysis is a muitivariate statistical method of interpreting a pattern of intercorrelations, in this case between statements on the consensus questionnaire. Using this technique, the 22 statements referring to physical health were transformed into smaller clusters of interpretable and relatively independent variables. The factor analysis and rotation according to the varimax principle resulted in three factors. The strongest factor, relating most closely to physical well-being consisted of 7 of the 22 questions. Further analysis of data refer to these 7 questions. Agreement and understanding were dichotomized with a cut-off point of three or more similarly answered questions. The consequent agreement/no agreement and understanding/no understanding groups were compared with respect to the similarity of opinion between the CPU therapist and the two external medical opinions on 
the presence of physical disease by means of the odds ratio (4). The odds ratio is a measure of association, quantifying the odds of similar opinion in case of agreement and understanding relative to the odds of a similar opinion in case of no agreement or no understanding. Factors which might influence complaint behavior physical health and consensus were accounted for by means of a logistic regression analysis.

\section{RESULTS}

Of the 218 eligible patients, $156(72 \%)$ participated in the screening; in the other cases either the patient and/or therapist actively or passively declined the medical evaluation over the 12 month study period. The average age of the participants was 45.5 years (range 23 62 years; mode 42 years). The group consisted of 56 men (36\%) and 100 women (64\%). All patients were known to have a DSM III axis I and/or axis II diagnosis. Forty-eight of them (30\%) had a psychotic disorder, $50(32 \%)$ had an affective disorder, and $53(34 \%)$ had a personality disorder. Thirty-three patients $(21 \%)$ were noted to have a borderline intellectual functioning (IQ 74-84). The average duration of psychiatric treatment to date was 4 years (range 1 - 31 years). Eighty-nine patients (57\%) were currently being treated with psychotropic medication.

Sixty-two patients (28\%) did not participate in the project. Of the whole research population only 30 patients (14\%) declined the medical evaluation. For half of the group of non-respondents, the CPU therapist advised against an evaluation for one reason or another. In 13 cases, there was either no contact with the patient or the patient could not be traced (no fixed residence).

The CPU therapist collected the same demographic and diagnostic data from both the respondents and the non-respondents. A comparison of respondents and non respondents showed no statistical differences in demographic data. As for diagnosis according to the DSM III, personality disorder, substance abuse, and psycho-organic disorders were overrepresented in the latter group.

The CPU therapist noted considerably fewer physical complaints in the non-respondent group: $52 \%$ as compared with $82 \%$ in the respondent group. The number of physical diseases, as diagnosed by the CPU therapist, was equal in both groups (33\%).

Physical complaints were present in the vast majority of the patients and were noted by all CPU therapists; a physical disease was reported by 43 patients (28\%). According to the CPU therapists and GPs, the number of patients with one or more physical diseases was $51(33 \%)$ and $49(31 \%)$, respectively. The specialist in internal medicine diagnosed 
physical disease in 82 patients $(53 \%)$. Further, and more detalled, epidemiological data are being published elsewhere (7).

In 68 patients $(37 \%)$ the patient and/or therapist version of the consensus questionnaire could not be completed. As Table 1 indicates, agreement and understanding of the therapists opinion remained most frequently unanswered, especially in patients with a psychotic, affective, or panic disorder. In about half of the psychotic and three-quarters of the panic disordered patients, the therapist could not form an opimion as to what he thought the patient would answer. Only for the group of 88 patients with a complete set of both versions of questionnaire consensus was measured.

Table 1 Complete versus incomplete consensus questionnaires per psychiatric diagnosis

\begin{tabular}{|c|c|c|c|c|c|c|}
\hline & \multicolumn{2}{|l|}{ Agreement } & \multicolumn{2}{|c|}{ Understanding $1 *$} & \multicolumn{2}{|c|}{ Understanding $\|^{* *}$} \\
\hline DSM $1 / 1$ disorders & complete & incomplete & complete & incomplete & complete & incomplele \\
\hline psychotic & 36 & 12 & 25 & 23 & 33 & 15 \\
\hline affective & 41 & 9 & 28 & 22 & 42 & $B$ \\
\hline panic & 17 & 7 & 14 & 10 & 14 & 10 \\
\hline personality & 46 & 7 & 37 & 16 & 45 & 8 \\
\hline substance abuse & 7 & - & 7 & - & 7 & 0 \\
\hline psycho-organic & 2 & 2 & 2 & 2 & 1 & 3 \\
\hline other & 11 & 1 & 10 & 2 & 11 & 1 \\
\hline deferred & 6 & - & 5 & 1 & 5 & 1 \\
\hline $\begin{array}{l}\text { borderline } \\
\text { intelligence }\end{array}$ & 26 & 7 & 22 & 11 & 26 & 7 \\
\hline $\begin{array}{l}\text { number of } \\
\text { patients }\end{array}$ & 125 & $\begin{array}{r}31 \\
{[20 \% 1]}\end{array}$ & $9 \overline{6}$ & $\begin{array}{r}60 \\
{[39 \%]}\end{array}$ & 122 & $\begin{array}{r}34 \\
{[22 \%]}\end{array}$ \\
\hline
\end{tabular}

* Understanding I: My opinion/how I think my therapist will answer this question.

** Understanding II: my opinion/how I think my patient will answer this question.

In the analysis, factors that might interact with complaint behavior, and consensus should be accounted for. Sociodemographic factors such as age, gender identity, and educational level have been reported to play an important role on complaint behavior (15). Psychiatric conditions are also known to play an important role.

Talbott and Linn (14) reported different reaction patterns of psychotic patients to lifethreatening disease than other patients. The obvious limitations in thought coordination and volition of many chronic psychotic patients in our chronic ambulatory population 
could seriously endanger the validity of consensus in this context and should therefore be waken into accownt when the data are analyzed and interpreted.

Finally complain behaviour as well as consensus will very likely be influenced by the medical of unmedical background of the CPU therapist.

In order to account for factors that most likely influence consensus, agistic regression analysis was applied to the data. Age below or abowe 40 years, gender identity, low or high eductional level psychotic, affective, panic, personality and psycho-organic disorders, as well as borderline intellectual functioning and discipline of the CPU therapist (psychiatrist, community psychiatric nurse, or social worker) were included in the logistic regression analysis.

Table 2 shows the estimated probabilities of a similar opinion between the CPU therapist and two external observers irrespective of consensus. For instance, the chance that CPU therapist and GP agree on the absence of physical disease is only $30 \%$. Only the probability of a similar opinion of CPU therapist and specialist for both the presence and absence of physical disease is statistically significant from what can be expected on the basis of random fluctuation.

Table 2 Estimated probabilities of a similar opinion between CPU therapist and two external observers adjusted for personal characteristics only.

\begin{tabular}{|l|l|l|l|l|l|l|r|}
\cline { 2 - 8 } \multicolumn{1}{c|}{$n=88$} & \multicolumn{3}{|l|}{ Speciallst } & \multicolumn{3}{l|}{} \\
\cline { 2 - 8 } & ND & D & total & ND & D & total \\
\hline CPU therapist & 27 & 69 & 89 & (S) & 30 & 30 & 63 \\
\hline
\end{tabular}

$N D=$ no physical disease

$D=$ physical disease

$S=$ signiflicant at 0,1 level

In Table 3 the influence of consensus on the odds of a similar opinion is given. For instance the chance that CPU therapist and GP agree on the absence of physical disease in case of consensus between patient and CPU therapist is $50 \%$. Understanding of the patients opinion as well as overall consensus did change the CPU therapists opinion towards that of the patients GP at a significance level of 0.1 . Consensus did not result in a change of opinion in the direction of that of the screening specialist in internal medicine. Thus agreement and understanding of the therapists' opinion seem to be less powerful opinion-changing factors than understanding of the patients' opinion. 
Table 3 Odds ratio's on physical wellbelng accounting for both consensus and personal characteristics; comparison between CPU therapist and two external observers.

\begin{tabular}{|c|c|c|c|c|c|c|c|}
\hline \multirow[t]{2}{*}{$n=88$} & & \multicolumn{3}{|c|}{ Specialist } & \multicolumn{3}{|l|}{$\Phi$} \\
\hline & & ND & $1 \mathrm{D}$ & total & ND & D & total \\
\hline \multirow{4}{*}{$\begin{array}{l}\text { CPU } \\
\text { therapist }\end{array}$} & agreement & 1,0 & 1,3 & 1,3 & 0,6 & 4,2 & 1,4 \\
\hline & understanding I & 1.8 & 0.7 & 1.4 & 1,3 & 1,2 & 1,5 \\
\hline & understanding \|I & 1,3 & 1,2 & 1.4 & 0,7 & $5,0 \quad(S)$ & 1,5 \\
\hline & consensus & 1,5 & 1.3 & 1,9 & 1,0 & 2,8 & 1,9 \\
\hline
\end{tabular}

ND $=$ no physical disease

$\mathrm{D}=$ physical disease

understanding | = my opinion/how | think my therapist will answer this question understanding $\|=$ my opinion/how $\mid$ think my patient will answer this question $S=$ significant at 0,1 level

\section{DISCUSSION}

The results of the analysis in this study provide some support for the hypothesis that the assessment of physical disease in chronic ambulatory psychiatric patients changes in the direction of that of the patients' GP when the patient and CPU therapist are more in consent on the presence of physical disease in the patient. Some support only, as the statistical significance reaches only as far as the 0.1 level. A much larger sample size is necessary to give more solid ground to our hypothesis, as chronic psychiatric patients are a heterogeneous group, and vary widely in both psychiatric diagnosis and sociodemographic variables (1). Our hypothesis will therefore not be true for all groups of psychiatric patients, especially for those who are sewerely limited in coordinating and in expressing their thoughts and feelings, a well-known phenomenon in psychotic disorders. These disorders make mutual understanding an often unattainable goal as table 1 illustrates. In our relatively small sample, this phenomenon was not limited to psychotic disorders; as Table 1 suggests, it also extended to affective and panic disorders. This could possibly be explained for affective disordered patients as they might also have been diagnosed with a psychotic disorder. In panic disordered patients one could speculate that an abundance of physical symptoms related to the autonomous nervous system unfavourably influences agreement and understanding. 
The concept of consensus as defined in this paper is a rather unusual one in medicine. The outcome of this study needs confimation by means of further research on a larger and/or more homogeneous sample size, as consensus could have implications for daily practice in community care for chronic psychiatric patients. A routine physical screening procedure should then be indicated for some groups of chronic patients whilst for other groups consensus might form a reasonable and practical solution as a means of physical screening.

\section{REFERENCES}

1. Bachrach LL: Defining chronic mental illness: a concept paper. Hospital and Community Psychiatry 39: 383-388, 1988

2. Koranyi EK: Morbidity and rate of undiagnosed physical illness in a psychiatric clinic population. Archives of General Psychiatry 36: 414-419, 1979

3. Hall RCW, Gardner ER, Stickney SK, et al: Physical illness manifesting as psychiatric disease. Archives of General Psychiatry 37: 989-995, 1980

4. Hoffman $\mathbb{R S}$, Koran LM: Detecting physical illmess in patients with mental disorders. Psychosomatics 25: 654-660, 1984

5. Ananth J: Physical illness and psychiatric disorders. Comprehensive Psychiatry 25: $586-593,1984$

6. Maricle RA, Hoffman WF, Bloom JD, et al: The prevalence and significance of medical illness among chronically mentally ill outpatients. Community Mental Health Journal 23: 81-90, 1987

7. Honig A, Pop P, Tan ES, et al: Physical illness in a chronic psychiatric patients from a community psychiatric unit: the implications for daily practice. British Journal of Psychiatry 155: 58-64, 1989

8. Derogatis LR, Lipman RS, Rickels $\mathrm{K}$, et al: The Hopkins Symptom Checklist, A self-report symptom inventory. Behawioral Sciences 19: 1-15, 1974

9. Luteijn F, Hamel LF, Bouwman TK, Kok AR: HSCL The Hopkins Symptom Checklist Manual, Lisse, Swets \& Zeitlinger, 1984

10. Summers WK, Munoz RA, Read MR: The psychiatric physical examinations. Part I: methodology. Journal of clinical psychiatry 42: 95-98, 1981 


\section{UITLEIDING}

Deze titel zal U misschien enigszins bevreemden en behoeft enige uitleg. Bij de voorbereiding van dit manuscript drukte een van mijn promotoren mij op het hart: "Neem ruim de tijd voor het schrijven van de in-en uitleiding". Een bundel artikelen met een nietje erdoor vond hij toch wat slordig. Hoewel ik het met deze laatste opmerking zeker eens was, begreep ik niet geheel wat hij met "uitleiding" bedoelde; het gaf me prettige associaties met: eindelijk uit mijn lijden te worden verlost. Zoveel mededogen had ik zelfs van mijn promotor niet verwacht. Ik zocht het op in Van Dale, Groot Woordenboek der Nederlandse Taal (1985) en zie daar, weer kon ik van zijn wijsheid genieten.

Uitteiden, het nest is uitgeleid, de jongen zijn uitgevlogen.

Dit hoofdstuk had geen symbolischer titel kunnen dragen; het beoefenen van de wetenschap staat immers in het teken van de overdracht van kennis ("de jongen" ${ }^{\text {") }}$. Zeker als lezing van een proefschrift beperkt blijft tot het lezen van de conclusie of samenvatting is het schrijven van deze twee hoofdstukken van vitale betekenis.

Ik betrap me erop dat ik nu toch iemand citeer aan het begin van mijn betoog, terwijl ik in de inleiding juist de reden aangaf om dit niet te doen. Gelukkig kan dit citaat van een weerwoord voorzien worden en mij ongetwijfeld definitief doen besluiten nooit meer te citeren.

Aan het begin van dit proefschrift heb ik een aantal onderzoeksvragen geformuleerd die nu elk afzonderlijk een antwoord behoeven. Vervolgens zou ik enige aanbevelingen willen doen aan collegae hulpverleners in de ambulante geestelijke gezondheidszorg om de omgang met lichamelijke klachten en afwijkingen bij de chronische psychiatrische patiènt te bevorderen.

In de inleiding heb ik beloofd hier terug te zullen komen op de geschetste ziektegeschiedenis. lk zal dat doen middels een systemische analyse zoals aangegeven in hoofdstuk twee. De praktische consequenties van mijn aanbevelingen in de omgang met somatiek zullen toegelicht worden met behulp van deze ziektegeschiedenis. 


\subsection{Ordewing in de chaos}

Hoe kan lichamelijk onwelbevinden worden onderkend uit de vele problemen van de ambulante chronische psychiatristsche patientu?

Als antwoord op de wraag werd in hoofdstuk 2 een hulpinstrument, de probleemanalyse, aangereikt. Deze wijze van inventarisatie geeft structuur aan in de omstandigheden van en rondom de patiěnt. In de probleemanallyse worden vier probleemgebieden onderscheiden, die elk afzonderlijk beschouwd kuninen worden (zie paragraaf 1.2). De probleemanalyse wordt gebruikt om een werkhypothese te ontwerpen waarin verschillende gegevens en gebeurtenissen van en rond de patiënt een plaats krijgen. De rol van deze anamnestische en biografische gegevenheden in het ontstaan en verloop van de ziektegeschiedemis kan op deze wijze werduidelijkt worden. De rol van deze gegevens op het eerste nivo (orgaan nivo) zal in paragraaf 8.5 in relatie worden gebracht met patiënte's problemen op andere nivo's van functioneren.

Laten we nu teruggaan naar de ziektegeschiedenis uit de inleiding en hierop retrospectief de probleemanalyse toepassen.

Patiente werd naar onze afdeling verwezen door de polikliniek van het lokale psychiatrische ziekenthuis.

Zij was daar vijfmaal opgenomen geweest; voor het eerst op haar $17 \mathrm{e}$ jaar; de laatste opname dateerde van twee jaar voor aanmelding. Anderhalf jaar verbleef $z i j$ in een therapeutische gemeenschap. Toen liep ze weg en sloeg aan het zwerven. In totaal was zij drie jaar opgenomen geweest. Tot aan haar laatste opname woonde zij in een klein appartement. Patiënte weigerde sinds haar ontslag antipsychotische medicatie en was al ruim drie maanden niet meer op haar poliklinische afspraken verschenen. Nadat patiẻnte enkele weken ook niet meer bij haar ouders verschenen was, werd door haar ouders hulp gezocht bij de psychiatrische polikliniek; deze instantie zorgde voor aanmelding van patiënte bij de Sociaal Psychiatrische Dienst.

\section{Nivo 1, het orgaannivo:}

1. Welke symptomen en/of klachten aijn er op dit nivo?

Rugklachten.

Slechte lichamelijke verzorging.

2. Waaraan wijt de patiënt deze symptomen en/of klachten?

Onbekend, een nadere anamnese is niet af te nemen. 
3. Bestaat er een organische grondslag woor de genoemide verschijuselen?

Zo ja, welke?

Onbekend.

4. Is er sprake wan een Ernstig of Nhet Ernstig lichamelik lijden?

Onbekend.

5. Hoe zeker bent U ervan dat er sprake is van een lichanelijke ziekte?

Niet te beoordelen op dit moment.

6. Indien niet duidelijk is wat de oorzaak is van de lichamelijke werschijnselen, welke stappen gaat $U$ dan ondernemen om duidelijkheid te verkrijgen? (bijv. informatie opuragen, nader onderzoek door $U$ zelf of een ander, etc.)

Haar ouders vertellen dat zij behoudens kinderziekten lichamelijk altijd goed gezond is geweest en dat zij niet bekend is met medicijn- of drugsgebruik.

Patiënte's gedrag belemment verdere evaluatie.

7. Indien één of meerdere verschijnselen wan organische aard zijn, zijn er dan redenen om daaraan in Uw behandeling aandacht te geven?

$Z$ o ja, welke aandacht gaat $U$ geven en wat denkt U daarmee te bereiken?

Zo nee, waarom niet?

Deze vragen zijn niet te beantwoorden wegens gebrek aan medewerking van patiënte.

8. Zijn er aanwijzingen, dat de lichamelijke verschijnselen van funktionele aard zijn en zo ja welke argumenten bestaan daarvoor?

Patiênte's ouders vertellen dat hun dochter waak lichamelijke klachten heeft op momenten dat zij wil dat anderen wat woor haar doen, zoals boodschappen. Ze laat zich alle zorgen dan goed welgevallen.

9. Welke positieve entof negatieve konsekwenties hebben de genoemde lichamelijke klachten of ziekten op de verschillende nivo"s?

Dit is op dit moment niet te beoordelen.

10. Indien er sprake is van funktionele klachten, bent $U$ dan van plan op dat nivo re behandelen (bijv. ontspanningsoefeningen, psychofarmaca).

Geef aan wat $U$ daarmee denkt te bereiken.

Indien $U$ miet op dit nivo wilt behandelen, waarom dan niet? 
Hoewel er hetroanamnestisch aanwijzingen zijn die pleiten voor een functionele verklaring wan de rugklachten kan dit niet nader geobjectiveerd worden wegens gebrek aan medewerking van patiënte.

\section{Nivo 2, nivo van het individu:}

1. Welke klachten enlof verschijnselen vindt $U$ dat een aanwijzing vormen voor mentale funktiestoornissen bij deze patiënt?

Patiënte converseert hardop met mensen die ik niet kan waarnemen. Patiënte leeft temidden van kapot geslagen meubelen, is slecht verzorgd. $\mathrm{Zij}$ is niet in staat enige sociale contacten te maken of te handhaven; zij gedraagt zich agressief ten aanzien van medebewoners.

Recidiverende exacerbaties van psychotische episodes sinds $17 \mathrm{e}$ jaar, gepaard gaande met geleidelijk toenemende sociale desintegratie. Tijdens derde opname werd diagnose schizofrenie gesteld.

2. Is er sprake van zwakbegaafdheid? Op grond van welke argumenten konstateert $U$ dat er sprake is van zwakbegaafdheid (doublures, abstractienivo, psychologische test, etc.). Zo ja, denk aan de $V$-code onder vraag 3 . Indien er psychodiagnostische gegevens beschikbaar zijn, gaarne deze vermelden met de datum van het onderzoek.

Nee, gezien opleidingsnivo en schoolresultaten tot aanvang ziektegeschiedenis.

3. Is er uu sprake van een klinisch syndroom of een toestand die niet toe te schriven is aan een psychische stoornis, maar die een punt van aandacht of behandeling is $(V$ code)?

D.S.M.-III klassificatie volgens As I:

Schizofrenie, paranoide type 295.34 .

4. Is er nu sprake van een persoonliikheidsstoornis of een specifieke ontwikkelingsstoornis?

D.S.M.III klassificarie volgens As II: geen

5. Welke van de bovengenoemde bevindingen komen voor behandeling in aanmerking of beinvloeden de behandeling?

Geef aan warom. 
Welke behandeling staat $U$ voor ogen?

Psychotisch toestandsbeeld, wegens de schade die deze toestand voor patiente en haar omgeving teweegbrengt.

Depot neurolepticum in eerste instantie; daamaast interventies op andere nivo's.

6. Welke van de bovengenoemde bevindingen komen miet in aanmerking voor behandeling en waarom niet?

Geen.

7. Geeft de biografische anamnese bij deze pariënt $U$ redenen om de aanwezigheid van ontwikkelingsstoornissen te veronderstellen zoals die beschreven worden door

\section{Erickson?}

Zo ja, welke ontwikkelingsstoornis acht U aanwezig?

Patiènte groeide op als de middelste van drie dochters. Haar moeder moest vaak meehelpen in de groentezaak van haar man. Daardoor was er weinig tijd voor de kinderen die zichzelf maar bezig moesten houden. Patiënte leerde graag en goed. Ze had een paar goede vriendinnen, met wie ze haar hele middelbare schooltijd heeft opgetrokken. Op de HAVO begon haar gedrag te veranderen. Ze bleef in de derde klas zitten. De straat durfde zij niet meer op, probeerde zich te verbergen en bleef in bed liggen. Ook het contact met haar vriendinnen weerde ze af. De mensen op strat zeiden de vreselijkste dingen over haar, ze dacht dat ze gemarteld zou worden. In die periode werd het groentebedrijf van haar vader failliet verklaard; moeder was definitief thuis. Na haar eerste psychotische periode trad er een gelleidelijke achteruitgang in haar nivo van psychosociaal functioneren in met gebrekkige dagvulling en gebrekkige deelname aan het maatschappelijk verkeer.

Patiënte heeft een normale ontwikkeling doorgemaakt tot aan haar puberteit. Van een ontwikkelingsstoomis in engere zin is geen sprake; veeleer van een ontwikkelingsstagnatie dan wel-regressie in de puberteit.

8. Hebben de door $U$ beschreven ontwikkelingsstoormissen konsekwenties voor $U$ w behandeling/begeleiding?

Zo ja, welke?

Ja, patiënte is niet in staat geweest om los van haar ouders te kunnen functioneren. Ouders fungeren nog als verzorgers van hun dochter, in overeenstemming met hat huidige gestagneerde ontwikkelingsniwo. Gezien het bovenstaande dient deze rol. van de ouders door de hulpverlening op dit moment ondersteund te worden. 
9. Hobt U redenen om aan themen dat er sprake is wan een gestoorde socialisatie.

(Hoe is de losmaking van her thuismilieu verlopen? Hoe is de aansiniting met anderen buiten de kleine groep? etc.).

Welke konsekwenties heeft dit voor Uw handelen?

Ja, er is sprake van een ernstig gestagneerde socialisatie. De losmaking van thuis heeft niet plaatsgevonden. Er is nauwelijks contact met leeftijggenoten of anderen. Dientengevolge zal een vorm wan resocialisatie ter hand genomen moeten worden met in achtneming van de huidige ontwikkelingsbeperkingen van patiënte.

\section{Nivo 3, nivo van de kleine groep}

1. Waaruit bestaat "het gezin"?

Hoe is de ontwikkeling wan dit gezin? (bijw de gezinsachtergronden van de verschillende partners?)

Patiènte is middelste van drie dochters. Tussen elk van de kinderen zit anderhalf tot twee jaar leeftijdsverschil. Haar beide zusters zijn sinds hun $18 \mathrm{e}$ jaar wit huis en gehwwd. Beiden wonen in het westen; patiënte heeft op feestdagen soms wel eens contact met hen.

Vader is nu autorijschoolhouder, 53 jaar oud.

Moeder is huisvrouw, 50 jaar. Zij verzorgt de administratie van het bedrijf van haar man.

Het gezin is het beste te typeren als een typisch hard werkend middenstandsgezin.

Dit is niet verwonderlijk daar ook de ouders uit een middenstandsmilieu voortkomen. Doorzetten en goed je best doen zijn belangrijke begrippen.

\section{Erobleemdefiniëring}

Hoe definiëren de "gezinsleden" de problemen zoals die aan de hulpverlener worden aangeboden, inklusief de rol die de patiënt hierin speelt?

Graag zo letrerlijk mogelijk zonder interpretatie van hulpverlener.

Moeder verwijt zichzelf nu nog steeds te weinig aandacht aan haar dochter te hebben besteed. "Als het fout gaat met je kind, is het eerste wat je denkt dat het aan jou ligt, dat er te veel ruzie is geweest of $\mathrm{zo}^{\prime \prime}$ ",

Vader zegt" "Want dat is het tragische bij mijn dochter: ze weet wat er aan de hand is. Als je nu zwakzinnig bent of een mongooltje ....". "Ze nam ons kwalijk dat we haar stemmen niet geloofden. Dat is het probleem: ze denkt niet dat ze zulke dingen hoort, ze hórt ze gewoon".

Sinds patiẻnte's derde opname hebben haar problemen voor de ouders een naam. 
Kort daarvoor had haar vader in een flits beseft dat ze iets had dat nooit zou overgaan, iets dat inherent was aan haar persoon, haar bestaan. En toen opeens was er een psychiater die het bevestigde: "Uw dochter is schizofreen":

"Onverdraaglijk" zegt moeder. "Die gedachte dat we een kind op de wereld hebben gezet dat het niet...kan".

"Ze kan een eenvoudig, tamelijk beschermd bestaan leiden. Dat is het hoogste wat je kunt bereiken", zegt de vader. "Daar werken we aan", zegt de moeder.

\section{Hiërarchie, flexibiliteit en grenzen}

Iedereen in dit gezin heeft zijn duidelijke taak en rol; deze zijn weinig onderhevig aan verandering. Vader zet het beleid uit ten aanzien van de wijze van omgang met de dochter. Vader nam het initiatief om opnieuw professionele hulp te zoeken voor zijn dochter, zoals hij dat wel vaker heeft gedaan.

Moeder regelt de huishoudelijke en financiële zaken daar ombeen.

De twee andere dochters zijn niet meer betrokken bij dit gezinssysteem.

Patiënte functioneert in dit gezin als de onwolwassen dochter die voor al haar basale behoeften afhankelijk is van haar ouders.

\section{Hypothesevorming}

In de loop der jaren hebben de ouders een wijze van omgang gevonden met hun dochter en haar ziekte. Door deze wijze van omgang hebben de ouders enige zekerheid dat hun dochter onderdak, voeding, kleding en zakgeld heeft. Dit heeft een redelijke stabiliteit bevorderd in het bestaan van de dochter de afgelopen twee jaar.

\section{Konklusie}

Geeft het bovenstaande aanleiding tot het geven wan aandacht hieraan in het verdere algehele behandelingsplan?

Zo ja, welke interventies overweegt U?

Zo nee, waarom niet?

Zoals ook genoemd bij nivo 2 lijkt de verzorgende rol wan de ouders stabiliteit bij patiente te bevorderen en dient deze rol ondersteund te worden door de hulpverlening.

6. Impentarisatie van het sociale netwerk en consequenties voor de behandeling Patiënte heeft een zeer beperkt sociaal netwerk, zowel kwantitatief als kwalitatief. Voor haar affectieve behoeften is patiënte volledig aangewezen op haar ouders en 
in mindere mate op een oude schoolwriendin.

Aansluting by leeftijdsgenoten of medepatienten heeft zij niet. Voor haar materiele behoeften is zij via haar ouders afhankelijk van sociale instanties en de gezondheidszorg. Patiènte is geen lid van verenigingen of belangengroeperingen. Door haar gedrag wordt zij geleidelijk uitgestoten uit haar woonomgeving. De enige contacten met haar buren verlopen conflictueus.

Er dient witgebreid aandacht te worden besteed aan het uitbreiden van patiënte's sociale netwerk, onder andere in de sector vriendschappelijke betrekkingen. Met name het bevorderen van aansluiting bij lotgenoten kan daar een eerste stap in vormen.

\section{Nivo 4 , de organisatie van groepen}

\section{PSYCHOTRAUMA EN MAATSCHAPPELIJKE VERANDERINGEN}

1. Welke belangrijke "life-events" hebben zich in het leven van de patiënt voorgedaan? Welke konsekwenties hebben deze gebeurtenissen gehad? Op het maatschappelijk nivo speelde zich een traumatische gebeurtenis af aan het begin van haar ziektegeschiedenis: het failliet gaan van de groentezaak van vader. De symbolische betekenis van de stemmen die patiënte in die periode waarnam kunnen zeker worden gezien in relatie tot het faillisement van vaders bedrijf. Bedreigd als het gezin zich in deze periode voelde door de buitenwereld kreeg het begrip doorzetten en goed je best doen nog meer betekenis. Patiënte kon hieraan niet meer voldoen. Haar rol als scholiere, haar plaats in het gezin en contact met haar vriendinnen kalfden langzaam maar zeker af. Zij werd in toenemende mate onzelfstandig en werd afhankelijk van verzorging door anderen, met name haar moeder. Haar sociale uitkering wordt beheerd door haar vader. Hij betaalt daarvan haar huur en geeft har weekgeld. Meestal komt patiènte een maal per week thuis; ze brengt dan haar was en eet mee.

2. Welke van de beschreven konsekwenties wilt $U$ beinvloeden?

Denk met name ook aan de mogelijkheid een geleden verlies te kompenseren qua rolvervilling, struktuur en referentiegroep en andere sociale aftakelingsverschijnselen. In welke mate kunt $U$ de maatschappelijke belangen van de patiënt behartigen en de maatschappelijke positie verbeteren? 
Zij zal, evenals haar familie en buren, door de hulpvertening op hele praktische wijze ondersteund moeten worden wil de zelfverwathlozing en verwaarlozing van haar flat niet tot al te grote problemen leiden.

Zoals hierboven wordt geillustreend geeft de probleemanalyse de mogelijkheid om bijvoorbeeld lichamelijke klachten, die ondergesneeuwd dreigen te worden onder problemen op andere nivo's te inventariseren en niet over het hoofd te zien. De probleemanalyse is te hanteren door elke hulpverlener van een sociaal psychiatrische dienst, onafhankelijk van zijn/haar basisdiscipline en toepasbaar voor elke ambulante chronische patiènt en elke soort chronische problematiek of aard van de hulpvraag.

Op het zinvol gebruiken van de probleemanalyse voor zover het de samenhang tussen het orgaannivo en de andere drie nivo's betreft zal nader worden ingegaan in paragraaf 8.5.

Een algehele werkhypothese, nodig voor het opstellen van een revalidatieplan is hier niet aan de orde en zal daarom achterwege worden gelaten. Allereerst zou ik nu cen samenvatting willen geven van de resultaten van het epidemiologische gedeelte van het onderzoek.

\subsection{Het lichamelijk welbevinden van de ambulante chronische psychiatrische patiënt.}

Wat is de aard, ernst en omvang van lichamelijke klachten en ziekte bij de ambulante chronische psychiatrische patient?

In zijn algemeenheid is deze vraag niet te beantwoorden. Het is namelijk de vraag of de resultaten van mijn onderzoek bij onze populatie generaliseerbaar zijn voor andere groepen ambulante chronische psychiatrische patiènten. Waar mogelijk zal ik een vergelijking maken tussen mijn bevindingen en die uit recente onderzoeken bij gelijksoortige populaties.

\subsubsection{Epidemiologische gegevens over frequentie, ard en ernst wan lichamelijke ziekten.}

In mijn onderzoek is niet alleen de mening van de internist als "gouden standaard" genomen, maar ook die van de huisarts van de patiënt. Beiden zijn medici matar beoordelen de patiềnt vanuit een ander perspectief. 
Voor de internist betreft het een eenmalige keuring van een hem voordien onbekende patiênt in een voor de patiënt over het algemeen ongebruikelijke omgeving (een polikliniek); de visie van de internist is een momentopname, die tot stand is gekomen door het initiatief van anderen dan de patiënt zelf; de patiënt is systematisch bevraagd en onderzocht in het kader van een onderzoeksproject.

De huisarts van de patiënt is vaak al lange tijd met diens problematiek en voorgeschiedenis bekend en is ook vaak op de hoogte van diens thuismilieu en familiegeschiedenis. Het initiatief voor consultatie gaat daarbij gewoonlijk van de patiënt uit. Het door de huisarts verrichte onderzoek is vaak probleemgeoriënteerd, ingebed in een hem bekend milieu van en rond de patiểnt.

Een oordeel van de internist en de huisarts van de patiënt tesamen zal daarmee een beter referentiepunt of gouden standaard opleveren dan elk oordeel afzonderlijk. Een voorwaarde daarbij is natuurlijk dat alle betrokkenen dezelfde definitie van lichamelijke ziekte hanteren, namelijk: die klachten, symptomen of bevindingen die een medische behandeling behoeven of waarbij nader medisch onderzoek is geindiceerd ter diagnostisering c.q. uitsluiting van een vermoede ziekte. De huisartsenpraktijk is een, voor de hulpverlener van een Sociaal Psychiatrische Dienst alsook de patiënt, eenvoudig toegankelijke somatische dienstverlening en daarmee in de dagelijkse praktijk het meest haalbare referentiepunt (zie ook paragraaf 1.4.3.2.).

Uit tabel 1 blijken de patiënt, de hulpverlener van de Sociaal Psychiatrische Dienst en de huisarts aan de ene kant en de internist aan de andere kant nogal fors te verschillen wan mening over de aanwezigheid van lichamelijke ziekte bij de patiënt.

Tabel 1 Percentages patiënten met lichamelijke klachten en ziekten volgens de pattënt, de hulpverlener van de Sociaal Psychiatrische Dienst, de huisarts en de internist

\begin{tabular}{|c|c|c|c|c|}
\cline { 2 - 5 } \multicolumn{1}{c|}{$n$ Patiènt } & S.P.D. & \multicolumn{1}{c|}{ huisarts } & internist \\
\hline lichamelijke klachten & $88 \%$ & $83 \%$ & $77 \%$ & $83 \%$ \\
& $n=137$ & $n=130$ & $n=120$ & $n=129$ \\
\hline lichamelijke zlekten & $28 \%$ & $33 \%$ & $31 \%$ & $53 \%$ \\
& $n=43$ & $n=51$ & $n=49$ & $n=82$ \\
\hline ernstige lichamelijke & & $6 \%$ & $4 \%$ & $7 \%$ \\
ziekten & & $n=9$ & $n=6$ & $n=11$ \\
\hline
\end{tabular}

Duidelijk is dat de patiënt zichzelf niet lichamelijk zieker beschouwt dan elk van de andere beoordelaars!

De door ons geconstateerde percentages lichamelijke ziekten zijn moeilijk te vergelijken met die van Barnes e.a. (1983). In 26\% ( $n=38)$ van hun patiënten vonden zij een of meer 
lichamelijke ziekten. De verschillen in gevonden percentages ziekten met die in onze populatie hangt mogelijk samen met selectiecriteria van Barnes. Patienten die het afgelopen jaar om welke reden dan ook al een medisch onderzoek hadden ondergaan werden uitgesioten. In een recenter onderzoek beoordeelden Maricle e.a. (1987) 53 \% wan hun patiënten als "in need of some form of medical attention", overeenkomend met de door ons gevonden percentages.

De grote verschillen in frequentie van onderkende lichamelijke ziekten wordt aanzienlijk minder, althans tussen de hulpverlener van de Sociaal Psychiatrische Dient en internist wanneer er naar ernst van de lichamelijke ziekte (in de zin van het leven bekortend) wordt. gevraagd. Een gradatie naar ernst werd noch vermeld in het onderzoek wan Barns e.a. (1983), noch in dat van Maricle e.a. (1987).

Tabel 2 geeft aan hoeveel van de gevonden somatische aandoeningen als zeker aamwezig. werden beschouwd. Uit deze gegevens kan geconcludeerd worden dat de huisarts en in mindere mate de hulpverlener van de Sociaal Psychiatrische Dienst zekerder zijn van de door hen geconstateerde lichamelijke aandoeningen dan de internist. Wellicht houd dit verband met het feit dat deze hulpverleners de patiënt over langere tijd volgden en de meeste ziekten all langere tijd bestonden. Het eenmalige contact van de internist met de patiënten vormt een verklaring voor het relatief hoge percentage door hem als niet zeker aangemerkte ziekten.

Tabel 2 Aantal zeker en niet zeker aanwezlge lichamelijke ziekten zoals gediagnostiseerd door de hulpverlener van de SPD, de hulsarts en de internist bij de 156 onderzochte sociaal psychiatrische patienten

\begin{tabular}{|l|r|r|r|}
\cline { 2 - 4 } \multicolumn{1}{c|}{} & SPD & hulisarts & internist \\
\hline zeker aanwezig & 39 & 62 & 56 \\
\hline niet zeker aanwezig & 29 & 11 & 56 \\
\hline
\end{tabular}

Over de aard van de gevonden ziekten is opmerkelijke eenduidigheid. Onze bevindingen komen geheel overeen met die van Bames e.a. (1983) en Maricle (1987). De aard van de nieuw gediagnostiseerde ziekten komt overeen met zilekten die dagelijks in elke doorsnee huisartspraktijk worden gezien en door de huisarts zelf worden behandeld (zie voor een gedetailleerde beschrijving van de door de internist gediagnostiseerde ziekten bijlage 1). In de Angelsaksische literatuur worden deze ziekten ook wel aangeduid met de term "minor diseases". Ziekten die behandeling behoeven doch onder normale omstandigheden geen dramatische inwloed hebben op het algehele (on)welbevinden van de patiënt. De gevonden ziekten beperken zich niet tot bepaalde orgaansystemen of groepen stoornissen 
en zyn tiet te concentreren binnen bepaalde medische speciallismen zoals bijvoorbeeld de newrologie. De hechte telatie tussen de neurologie en de psychiatrie zoals die in het werleden vaak werd verondersteld en zich tot woor kort onder andere uitte in een verwevenheid van de opleidingen van beide specialismen wordt ook door deze studie niet bewarheild.

Opmerkelikk is dat alle aandacht van onderzoekers gericht is op die lichamelijke ziekten met een duidelijk antoonbare lichamelijke oorzaak. De functionele stoomissen, dat wil zeggen, stoomissen in het functioneren van een orgaan of orgaansysteem, die klachten veroorzaken, zonder dat daarvoor organische oorzaken aanwijsbaar zijn, (van Es, 1974) blijwen over het algemeen buiten beschouwing.

De internist registreerde bij 129 patiènten $(83 \%)$ spontaan geuitte lichamelijke klachten, bij het afnemen van de tractus anamnese oplopend tot 150 patiënten (96\%). In onze onderzoekspopulatie bleken 136 patiënten $(87 \%)$ een of meer aspecifieke lichamelijke klachten te hebben, dat wil zeggen klachten die niet in verband kunnen worden gebracht met een lichamelijke ziekte. (Fig. 1).Ter vergelijking werden bij slechts 47 patiënten (20\%) lichamelijke klachten gevonden waaraan een lichamelijke ziekte ten grondslag lag. Bij 114 patiënten ( $73 \%$ ) werden door de internist een of meer functionele stoomissen gediagnostiseerd.

Functionele stoormissen blijken althans in onze onderzoekspopulatie veel vaker voor te komen dan lichamelijke ziekten (Fig, 2). 
Figuur 1. Percentages specifieke en aspecifieke klachten bij de an het onderzoek deelnemende patienten, zoals gediagnostiseerd door de internist
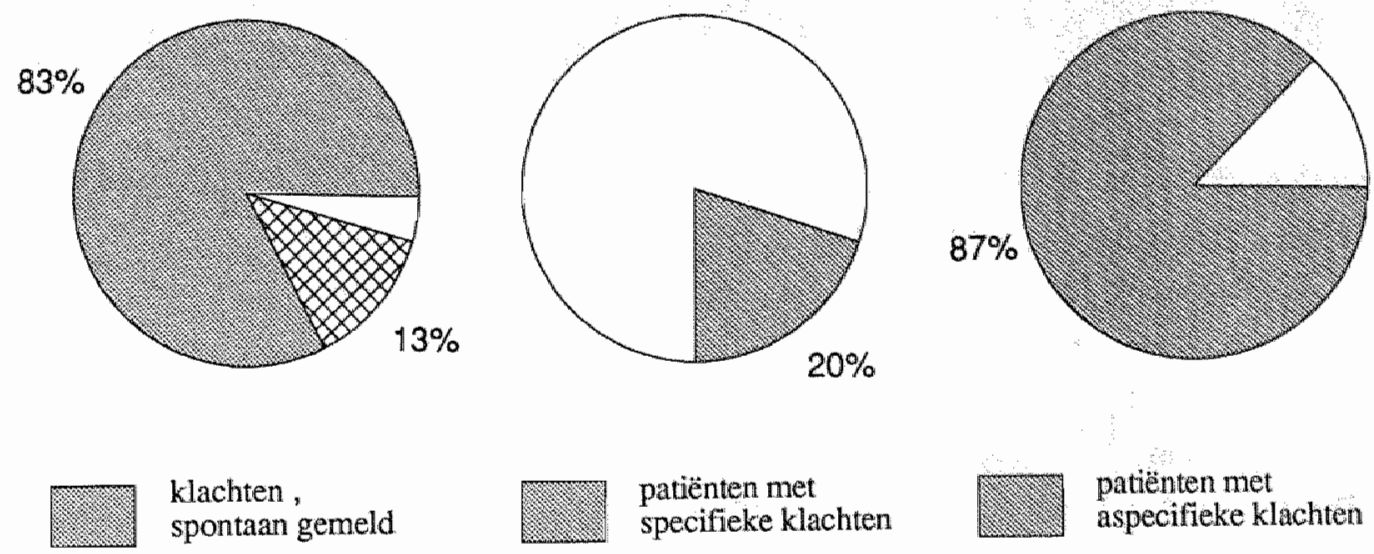

klachten,
spontaan gemeld

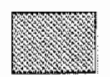

patiënten met

specifieke klachten

patienten met

aspecifieke klachten

klachten gemeld

via oppemen

anamnese

Figuur 2. Percentages lichamelijke ziekten en functionele stoornissen bij de aan het onderzoek deelnemende patiënten, zoals gediagnostiseerd door de internist.

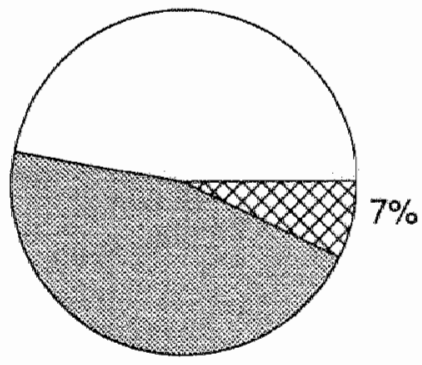

$46 \%$

lichamelijke ziekten

enstige lichamelijke ziekten

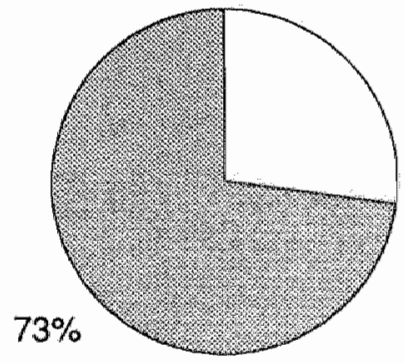

patiënten met

functionele stoornissen 
Bif de gevolgde diagnostische procedure, achtereenvolgens bestaande uit anamnese, fysisch diagnostisch onderzoek en laboratoriumonderzoek, blijkt het afnemen van een anamnese de meeste nieuwe en voor de somatische evaluatie bellangrijke gegevens op te leveren. Deze bevinding is in overeenstemming met eerder onderzoek op dit gebied (Hampton et al., 1975). Fysisch diagnostisch onderzoek blijkt na de anamnese het meest informatief te zijn (zie bijlage 2, tabel 1). Routine laboratoriumonderzoek levert relatief veel aspecifieke afwijkingen op (White en Barraclough, 1989), ook in ons onderzoek (zie bijlage 2, tabel 2 en 3 ). Bijlage 2 tabel 1 en 2 geven aan welke laboratoriumonderzoeken zijn uitgevoerd alsook het gevolg van de testuitslagen voor het medisch handelen .

\subsection{Miskenning van somatiek}

Hoe vaak wordt bij de ambulante chronische psychiatrische patiënt lichamelijke ziekte miskend?"

Zoals in de inleiding (paragraaf 1.4) al werd aangeduid is miskenning van lichamelijke ziekten een probleem dat onlosmakelijk is verbonden met de geneeskunde, zich niet beperkt tot psychiaters, maar ook voorkomt bij vele andere soorten specialisten, zowel in de ambulante sector als intramuraal.

Een viertal factoren die de kwantiteit van de miskende lichamelijke ziekten zou kunnen beinvloeden werden in de inleiding besproken (zie paragraaf 1.4.2 en 1.4.3).

In dit onderzoek werd één van deze factoren à priori uitgeschakeld, door elk van de participanten volgens eenzelfde definitie ziekte te laten beoordelen.

Overeenstemming over de aanwezigheid van éen of meer lichamelijke ziekten tussen de hulpverlener van de Sociaal Psychiatrische Dienst, de huisarts en de internist is constant en laag. Een hogere mate van overeenstemming is er over de groep van lichamelijk niet zieke patiênten (tabel 3). 
Tabel 3 Verschillen en overeenkomsten in beoordeling tussen SPD hulpverleners, huisartsen en internisi over aan- of afwezlgheld van éen of meer lichamelijke zlekten bij de 156 onderzochte patienten

\begin{tabular}{|l|l|l|r|r|}
\hline \multicolumn{2}{|c|}{ hulpverlener } & \multicolumn{3}{c|}{ beoordeling } \\
\hline+ & SPD & huisartsinteris & ziek & ziek \\
\hline & & & 51 & 105 \\
\hline & + & 49 & 107 \\
\hline+ & & + & 82 & 74 \\
\hline & + & + & 27 & 54 \\
\hline+ & + & + & 40 & 64 \\
\hline+ & + & & 29 & 76 \\
\hline
\end{tabular}

De huisarts en de internist diagnostiseerden in de onderzoeksgroep van 156 patienten respectievelijk 46 en 63 lichamelijke ziekten die bij de hulpverlener van de Sociaal Psychiatrische Dienst nog niet bekend waren. Geen van de nieuw gediagnostiseerde ziekten stond in oorzakelijk verband met het huidige psychiatrische ziektebeeld.

Gezien de bevindingen die dit onderzoek heeft opgeleverd rijst de vraag of en in welke mate er sprake is van miskenning van lichamelijke ziekten. De beoordelende medici zijn het in dit onderzoek met name oneens over die stoornissen die door de internist als een al dan niet zekere, het leven niet bekortende ziekte wordt ingeschat. Als medici het onderling bij deze categorie van diagnoses miet eens zijn over de aanwezigheid van ziekte kan mijns insziens niet van miskenning gesproken worden. De gegevens die beide soorten beoordelaars ter beschikking staan zijn blijkbaar voor meerdere interpretaties vatbaar. De huisarts en de internist zien de patiënt vanuit een geheel andere invalshoek (zie ook paragraaf 8.2 .1 ) en zullen daarom ook makkelijk van mening kunnen verschillen. Wie heeft er gelijk, wie heeft het meeste recht van spreken. Miskenning, onachtzaamheid, iets over het hoofd zien, duidt op het niet juist inschatten van, in dit geval, een lichamelijke ziekte; een tekortkoming in de hulpverlening dus. Wanneer deze wijze van definièring van miskenning wordt toegepast op de voorliggende onderzoeksresultaten dan is hiervan sprake bij die voordien niet bekende ziekten die door de internist zijn gediagnostiseerd als zeker aanwezig en her leven bekortend. In deze categorie zijn aanwijzingen van ziekte onomstotelijk aanwezig en ernstig van atard.

Bij 11 van de 156 onderzochte patiënten diagnostiseerde de internist 13 zeker aanwezige, levensbekortende ziekten. Bij acht van deze 11 patiënten was de hulpverlener van de Sociaal Psychiatrische Dienst en/of de huisarts van het bestaan van 9 ziektebeelden op de hoogte. Van de 13 door de internist geconstateerde levensbekortende ziektebeelden worden er door hen 4 miskend. 
Van miskenning kan ook gesproken worden wanneer een voor het psychiatrisch ziektebeel dantoonbare aorzakelijke lichamelijke ziekte is gemist.

Van deze tweede categorie miskende lichamelijke ziekten die bij behandeling ervan het psychiatrische ziektebeeld doen verdwijnen, de zogenaande "mimics", werd er geen enkele gediagnostiseerd. Vele van dergelijke vermoede ziekten bleken waak al meerdere keren uitgebreid onderzocht te zijn.

Voorts is er mijns inzivens een derde categorie van miskenning, namelij| in die gevallen waar lichamelijke stoornisser direct samenhangen met bijwerkingen wan door de betreffende hulpverlener zelf voorgeschreven medicatie. Ziekten als gevolg van bijwerking van door psychiaters van de Sociaal Psychiatrische Dienst voorgeschreven psychofarmaca kwamen voor in zes gevallen.

De wijze waarop de term miskenning in de literatuur wordt gehanteerd (zie paragraaf 1.4) is gezien deze bevinding dan ook overtrokken en leidt mijns insziens tot een ongenuanceerde voorstelling van zaken en wat erger is, ondoelmatig handelen.

Totaal bedraagt het aantal miskende ziekten dan 10, indien de door mij aangehouden definiëring van miskenning wordt gehanteerd, namelijk 4 in de eerste en 6 in de derde categorie van miskenning. Deze getallen zijn zeker geen reden om, waar het miskenning van lichamelijke ziekten betreft, de alarmklok te luiden. Dit ondanks het feit dat er gén routine lichamelijke screening plaatsvindt binnen onze Sociaal Psychiatrische Dienst. Een goede samenwerking tussen de huisarts en de hulpverlener van de Sociaal Psychiatrische Dienst lijkt een zeer redelijk alternatief te zijn, dat echter gezien de matige overeenstemming tussen hulpverlener van de Sociaal Psychiatriche Dienst en huisarts (zie tabel 3) nog meer zou moeten worden bevorderd.

Een uitzondering voor deze wijze van screening dient echter gemaakt te worden voor de groep patiënten die psychotrope medicatie krijgt woorgeschreven. Juist bij deze groep werden direct met deze medicatie samenhangende ziektebeelden, zoals hypothyreoüde bij lithium niet onderkend. Dus niet alleen voor een optimale medicatietrouw van de patiënt is. regelmatige bloedspiegelcontrole alsook biochemische controle van die lichaamsfuncties die sterk beinvloed kunnen worden door de voorgeschrewen medicatie noodzakelijk. De coördinatie dient daarbij in eén hand te worden gehouden. De indicatie voor aanvullend laboratoriumonderzoek en de interpretatie van de verkregen gegevens hangen immers nauw samen met het klinisch beeld en dienen daarom in handen te zijn van de daarin geschoolde hulpverlener, namelijk de voorschrijvende psychiater.

Het was juist en absoluut noodzakelijk dat de overheid in 1986 besloot om RIAGG psychiaters de mogelijkheid te geven medicatie die door de verzekering wordt vergoed, voor te schrijven aan hun patienten. Zeker als de RIAGG's de "grote psychiatrie" en 
daamee het voorschrijven van psychofarmaca tot hun zorggebied willen rekenen (Hoogduin en de Haan, 1979).

De sociaal psychiater dient voor dit onderdeel van zorg rechtstreeks toegang te hebben tot de daarvoor noodzakelijke laboratoriumfaciliteiten zonder tussenkomst van andere hulpverleners en hun instanties zoals tot nu toe noodzakelijk is. Tot op heden is de bovenbeschreven tekortkoming in de hulpverlening helaas niet gesignaleerd an aan de orde gesteld.

\subsubsection{Miskenning bevorderende factoren}

Naar aanleiding van voomamelijk casuistische (voor)oordelen in de literatuur over de mate van zelfverzorging en medewerking aan een somatische evaluatie van de ambulante chronische psychiatrische patiënt (zie paragraaf 1.4.2) werd een observatielijst samengesteld die door de internist werd ingevuld na afloop van elke verrichte lichamelijke screening. Deze lijst bevatte 6 onderdelen die elk beoordeeld werden op een 5 punt schaal. Deze onderdelen waren: mededeelzaamheld bij het afnemen van de anamnese, herinneringsvermogen aangaande eigen ziektegeschiedenis, lichamelijke verzorging, motoriek, mate van medewerking en globale indruk van het contact. Een zelfde lijst vulde de internist in bij 147 voor leeftijd en geslacht gematchte nieuwe patiënten die regulier aan zijn polikliniek werden aangeboden. Bij geen van de scores bleken er significante verschillen te bestaan tussen de beide populaties. Het is niet uit te sluiten dat deze bevinding mede samenhangt met de uitvallers van de onderzoekspopulatie.

Natuurlijk kunnen hier geen absolute uitspraken aan verbonden worden, immers er was slechts éen beoordelaar en de beoordelingslijst was niet gevalideerd. Toch lijkt het gerechtwaardigd te stellen dat de tendens bestaat dat ambulante chronische psychiatrische patiënten zich op ongeveer dezelfde wijze presenteren aan een specialist in een interine polikliniek van een algemeen ziekenhuis als regulier aangeboden patiënten van een interne polikliniek dat doen.

De voorbereiding die nodig was om het contact tussen de internist en onze patient tot stand te brengen was echter aanzienlijk. Zo moest in een aantal gevallen door de betrokken hulpverlener van de Sociaal Psychiatrische Dienst woor vervoer naar en wan het ziekenhuis worden zorggedragen. Voorts was tijdens de polikliniek spreekuren, georganiseerd voor dit onderzoek, een sociaal psychiatrisch verpleegkundige aanwezig die de patiënten ontving en geruststelde, koffie serveerde en patiènten zonodig naar de verschillende laboratoria begeleidde. Dit alles resulteerde in $72 \%$ deelname aan dit 
onderzoek. Ter vergeljking: in her eerder aangehaalde onderzoek van Maricle (1987) weigerde $57 \%$ van de patiénten pasisief dan wel actief hun medewerking.

De zorgwuldige en ook praktische begeleiding vanuit een Social Psychiatrische Dienst zal het hoge percentage deelnemers as de lichamelijke screening in het algemeen ziekenhuis zeker bevorderd hebben. Het lijkt dan ook gerechtwaardigd te stellen dat wanneer men in de dagelijkse sociaal psychilatrische praktijk een somatische ewaluatie in een polikliniek van een algemeen ziekenhuis overweegt van iemand uit deze patiẻntengroep de hierboven beschreven praktische begeleiding een voorwaarde voor het welslagen ervan is.

De onderzochte groep ambulante chronische psychiatrische patiënten blijkt minstens even geregeld gebruik te maken van de huisarts, ja zelfs meer dan de gemiddelde Nederlander. Slechts $16 \%$ van de mannelijke en $13 \%$ van de vrouwelijke patiënten hadden in het jaar van onderzoek geen contact met hun huisarts. Vrouwelijke patiênten bezochten in het jaar van onderzoek hun huisarts gemiddeld $6.6 \mathrm{keer}$, mannen $4.5 \mathrm{keer}$. Deze getallen bedragen voor de gemiddelde volwassen Nederlander respectievelijk 4.1 en 2.9 (Swinkels, 1988). De door de huisarts gerapporteerde percentages lichamelijke ziekten komen ongeveer overeen met die van de hulpverlener van de Sociaal Psychiatrische Dienst.

Concluderend kan gesteld worden dat de onderzochte populatie ambulante chronische psychiatrische patiënten adequaat gebruik maakt van de eerstelijns gezondheidszorg. Immers de hulpverleners van de Sociaal Psychiatrische Dienst en de huisarts van de patient samen zijn op de hoogte van het merendeel van de ernstige somatische ziekten. De resocialisatie en reintegratie van de onderzochte patiëntenpopulatie is wat betreft het gebruik van le lijns gezondheidsvoorzieningen blijkbaar verder dan verwacht. Een intensieve samenwerking tussen de hulpverlener van de Sociaal Psychiatrische Dienst en de huisarts dient nog te worden gestimuleerd om hun overeenstemming over aan- of af wezigheid van lichamelijke ziekten te vergroten. Daamaast dient extra aandacht en zorg te worden gegeven aan bepaalde groepen met een verhoogd risico op een niet onderkende lichamelijke ziekte, zoals bijwoorbeeld patiënten die psychotrope medicatie gebruiken of patiënten die hun huisarts om welke redenen dan ook niet bezoeken.

\subsection{Somatische screeningsinstrumenten}

Is het mogelijk om een eenvoudig hulpinstrument te ontwikkelen om lichamelijke ziekten op te sporen bij ambulante chromische psychiatrische patiënten; een instrument dat gehanteerd kan worden door niet strikt medische disciplines? 
In hoofdstuk 1.5 werden de redenen aangegeven voor het ontwikkelen wan een eenvoudig, ook voor niet medici te hanteren instrument on lichamelijke ziekten op te sporen.

Allereerst werd de Hopkins Symptom Checklist (HSCL), een intemationalal veel gebruikte lichamelijke klachtenlijst, voor dit doel getoetst.

Als tweede werd overeenstemming tussen patient en hulpverlener over lichamelijk welbevinden van de patiënt onderzocht. De wijze van toetsing alsook de resultaten van beide onderzoeken werden uitvoerig besproken in hoofdstuk 6 en 7 . De resultaten zullen in de wolgende twee paragrafen kort worden samengevat.

\subsubsection{Een klachtenlijst als middel om lichamelijke ziekten op te sporen}

Kortweg is de volgende procedure gevolgd. De patiënt vult op de dag dat hij poliklinisch door de internist wordt onderzocht de klachtenlijst in. De HSCL is een klachtenlijst die door de patiënt zelf kan worden ingevuld. De patient geeft aan of, en in welke mate de 58 in deze lijst genoemde klachten voor hem van toepassing zijn gedurende de voorafgaande week. Vervolgens worden de antwoorden gekwantificeerd. Sicores van de HSCL worden daarna gecorreleerd met de inschatting van de huisarts van de patiënt en die van de onderzoeksinternist over aan- of afwezigheid van ziekte bij de patiënt.

De score op de HSCL bleek niet in staat om althans in onze onderzoekspopulatie de aanwezigheid van lichamelijke ziekten te kunnen voorspellen. Wel werd de score beïnvloed door het nivo van de opleiding, het al dan niet behandeld worden met psychotrope medicatie, het al dan niet gediagnostiseerd zijn met een psychotische stoornis, leeftijd en geslacht. Vrouwelijke patiënten gediagnostiseerd met een psychotische stoornis scoorden lager dan niet psychotische vrouwen. Hoger opgeleide patiënten scoorden lager in vergelijking met lager opgeleide patienten. De HSCL scores stegen met het toenemen van de leeftijd van de patienten.

Het was een aanzienlijke hulp geweest indien de score op een klachtenlijst een voorspelling had kunnen geven over de aan- of afwezigheid van lichamelijke ziekten. Gezien de bevindingen van dit onderzoek kan de HSCL althans voor dit doel niet worden geadviseerd. 


\subsubsection{Overeenstemming als middel om lichamelijke ziekten op te sporen}

Overeenstemming, de mate wastin hulpvrager en hulpverlener het eens zijn, kan beschouwd worden als maat voor de kwaliteit van de relatie tussen hulpverlener en patient. De mate van overeenstemming tussen patient en hulpverlener blijkt een voorspellende waarde te hebben voor het effect van psychotheraple. Analoog hieraan formuleerde ik de veronderstelling dat overeenstemming over lichamelijk welbevinden wan de patiënt een voorspellende waarde zou kunnen hebben voor het beter inschatten van lichamelijke ziekten door de hulpverlener. Onder beter inschatten wordt in dit verband verstaan het inschatten wan ziekte zoals een externe medicus (huisarts of keurend specialist) dat zou doen.

Door middel van een overeenstemmingsvragenlijst, (zie ook paragraaf 1.5 ) werd consensus tussen patient en hulpverlener gemeten. Met consensus werd in dit verband zowel inhoudelijke overeenstenming als owereenstemming naar wederzijdse perceptie bedoeld. De somatische inschatting wan de hulpverlener van de Sociaal Psychiatrische Dienst bij zowel de groep waarbij consensus, als bij de groep waarbij geen consensus bestond werd vergeleken met de inschatting van zowel de huisarts van de patiënt als de internist. Allereerst bleek de patiënt en/of de hulpwerlener in $37 \%$ van de gevallen geen antwoord te kunnen geven op de voorgelegde stellingen. Met name betrof dit de vraag hoe de ander de betreffende stelling zou beantwoorden. Uit de overgebleven $63 \%$ volledig ingevulde vragenlijsten werd enige steun gevonden voor de geformuleerde hypothese dat overeenstemming over het lichamelijk welbevinden van de patiënt een aanzienlijke bijdrage zou vormen aan de herkening van lichamelijke ziekten in de dagelijkse sociaal psychiatrische praktijk. De aantallen waren echter te klein om tot een definitieve bevestiging van de hypothese te kunven besluiten. Herhaling van dit onderzoek op een grotere populatie dient dan ook plaats te vinden.

\subsection{Samenhang tussen lichamelijke en andere probleemvelden}

Wat is de samenhang tussen lichamelijk welbevinden en onwelbevinden op andere probleengebieden van de ambulante chronische psychiatrische patiënt?

In paragraaf 8.3 omschreef ik de niet levensbedreigende ziekten of "minor diseases" als die ziekten die wel behandieling behoeven, maar geen dramatische invloed hebben op het algehele onwelbevinden van de patiënt. Ik voegde daaraan toe - onder normale 
omstandigheden -. Welnu de omstandigheder van ambulante chronische psychiatrische patiënten zijn vaak wat dat betreft niet nomaal. Deze patienten kunnen zich soms met slechts grote inspanning van henzelf alsook hun omgeving handhaven in de vrije maatschappij. De draagkracht en draaglast van deze patientengroep staan vaak op gespanmen voet met elkaar. De ziektegeschiedenis die ik $U$ in hoofdstuk 1 beschreven heb is daar een voorbeeld van. De betreffende problematiek heeft een parallel in de

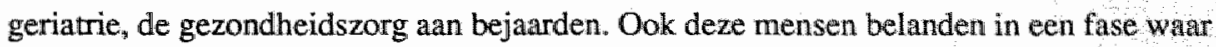
zij met hulp thuis kunnen blijven wonen, maar waar slechts een geringe aanleiding tot ermstige gedragsveranderingen kan leiden, zoals een intercurrente infectie. De optredende nachtelijke onrust of verwardheid kan dan vaak met eenvoudige medische diagnostiek en her behandelen van de infectie worden opgelost. Door de verminderde somatische vitaliteit van bejaarden en de dientengevolge vaak meer medisch gerichte hulpverlening zal een somatische evaluatie van deze populatie niet vaak over het hoofd worden gezien. Bij de ambulante chronische psychiatrische patiënt blijft onder vergelijkbare omstandigheden een somatische evaluatie vaak wel uit. Overleg met de huisarts van de patiënt en het (doen) uitvoeren van eenvoudige diagnostiek kan dan vaak een adequate vorm van crisisinterventie zijn.

In paragraaf 1.6.1 heb ik U een model aangeboden dat de relaties tussen verschillende probleemvelden van chronische psychiatrische patiënten nauwgezetter beschrijft dan het medische model. De samenhang tussen voordien als van elkaar onafhankelijk beschouwde probleemvelden wordt duidelijk met dit model. Een effectief behandelingsplan kan daarna volgen.

Ik zou $U$ nu de casus uit de inleiding weer in herinnering willen roepen door de problemen op elk van de vier nivo"s schematisch weer te geven. Vervolgens zal ik enkele relaties tussen de probleemvelden aangeven.

- rugklachten

- slechte lichamelijke verzorging

nivo 1 - gebruik wan lichamelijke klachten om iets gedaan te krijgen

- weigert antipsychotische medicatie

- normale ontwikkeling tot de vroege adolescentie

- stagnatie van de psychologische ontwikkeling in de puberteit

nivo 2

- chronisch paranoid-hallucinatoir toestandsbeeld in het kader van schizofrenie

- intelligentie boven gemiddeld 
nivo 3

- ouders winden dochter ziek en haar mogelijkheden beperkt

- ouders staan garant voor pariènte's basale levensbehoeften

- regelmatige contacten melt vader en moeder

- vrijwel geen contact met leeftijdsgenoten, lotgenoten of buren

- uitstotingsproces uit woonomgeving in volle gang

- leeft geisoleerd

- rolverlies als schollere en jong volwassen dochter

nivo 4

- geen zinvolle dagbesteding

- weigert contact met hulpverlening

- voorziet marginaal in eigen eerste levensbehoeften

Laat $i k$ U eerst een regelkring beschrijwen die gekenmerkt wordt door positieve (in casu instabiliteilt versterkende) terugkoppeling:

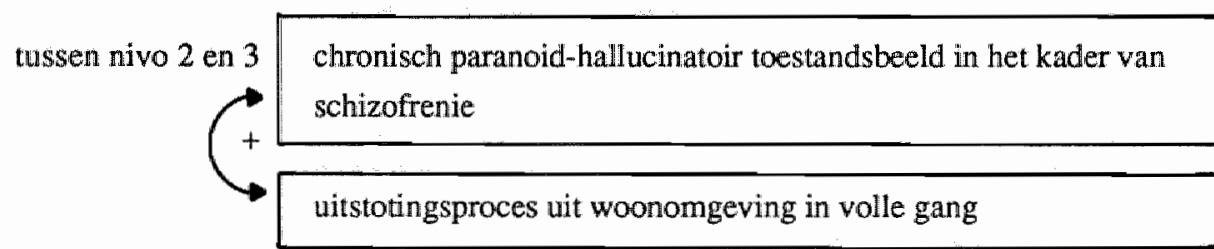

Gevolg: patiënte keent zich steeds meer af van de reeële buitenwereld; zil trekt zich terug in haar eigen droomwereld, overgeleverd aan haar stemmen en waanideeën; haar psychopathologie neemt toe in ernst, en daaraan gekoppeld toenemend controleverlies van patiënte over haar eigen gedachten en gevoelens.

Nu volgt een voorbeeld van een regelkring met een negatieve (in casu stabiliteit bevorderende) terugkoppeling"

tussen nivo 3 en 4: ouders staan garant voor patiënte's basale levens-

behoeften

voorziet marginaal in eigen eerste levensbehoeften

Gevolg: patiënte heeft in elk geval geld, eten, onderdak en schone kleding. Dit geeft stabiliteit aan haar bestaan. Reeds twee jaar verblijft zij op deze manier in een eigen woonongeving. 
Wat was nu de relatie tussen de lichamelijke ziekte en de andere probleemvelden van patiènte?

Hiervoor kan een aantal elkaar versterkende regelmechanusmen met een positieve terugkoppeling worden aangewezen: allereerst komt patiente door de pijn veroorzaakt door hav niersteen steeds minder de stratat op.

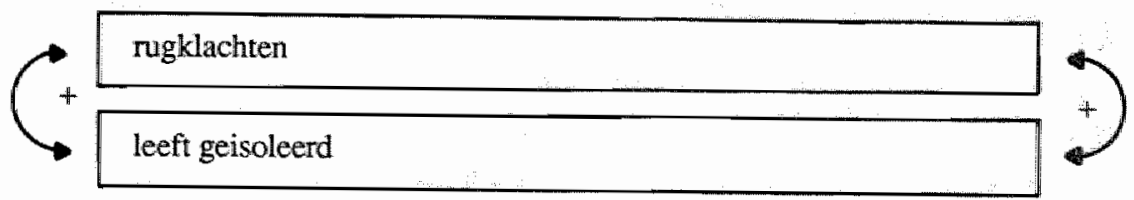

De isolatie neemt toe en zoals $U$ al gezien heeft in het eerdere voorbeeld van positieve terugkoppeling heeft sociale isolatie een versterkend effect op haar psychotische belevingen.

De wijze waarop zij lichamelijke klachten hanteert, leidde bij de ouders en ook bij mij tot de veronderstelling dat haar lichamelijke klachten iets anders uitdrukten dan lichamelijk dysfunctioneren: namelijk als voorwendsel om iets van de ander gedaan te krijgen. Haar klacht werd afgewezen, haar isolement nam toe. Een somatische evaluatie bleef uit, uiteindelijk met ernstige gevolgen.

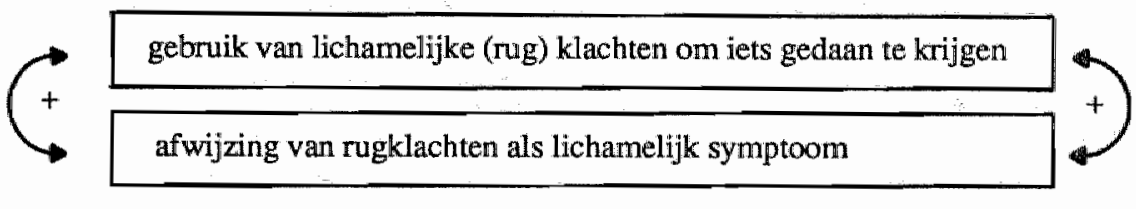

Een dysfunctie in dit geval op lichamelijk nivo heeft een kettingreactie tot gevolg gehad, uitmondend in een gedwongen opname. Ik had een ernstige lichamelijke ziekte miskend. Achteraf is het vaak makkelijk aan te geven hoe een casus wel aangepakt had moeten worden. Deze casus illustreert echter dat dit niet altijd het geval is. Zelfs all was de lichamelijke klacht van patiënte niet afgewezen en niet ondergesneeuwd onder haar evidente en emstige andere problemen, dan nog blijft het de vraag of patiente hulp had aanvaard om somatische diagnostiek en behandeling te kunnen doen plaatsvinden. Patièntes weerstand tegen behandeling had mogelijk doorbroken kunnen worden door haar huisarts in te schakelen. Deze had mogelijk wel toestemming gekregen om lichamelijk onderzoek te verrichten en laboratoriumonderzoek aan te vragen. Het nakijken van een plasje en behandeling van de urinewegontsteking had een verdere escalatie van patiëntes problematiek wellicht kunnen voorkomen. Een goede communicatie en 
samenwerking met degenen die de patient goed kennen is een voorwaarde om een dergelike problematiek te kunnen oplossen.

Ik hoop dat deze gevalsbeschrijving aan theeft kunnen tonen dat het toepassen van de probleemanalyse op patiente's problematiek inzicht geeft in de complexiteit van problemen van ambulante chronische psychiatrische patienten. Met de op deze wijze verkregen inzichten in de voorliggende problematiek kumnen we een revalidatieplan ontwerpen ter vergroting van de dragkracht van het systeem waarwan de patiënte deel witmaakt.

\subsection{Gevolgen voor de dagelijkse sociaal psychiatrische praktijk}

Om overzicht te krijgen over de complexe problematiek van ambulante chronische psychiatrische patienten is het allereerst noodzakelijk om in de eerste drie maanden van de intake-periode de verschillende probleemvelden wan de patiënt systematisch te inventariseren. De eerder beschreven probleemanalyse kan voor dit doel aangewend worden.

Bij de inventarisatie van lichamelijke problemen is het van belang na te gaan of de patiënt staat ingeschreven bij een huisarts en of hij/zij daarvan gebruik maakt. Indien dit het geval is dient de hulpverlener van de Sociaal Psychiatrische Dienst bij het vermoeden van somatische problemen na ruggespraak met en toestemming van de patiënt contact met de huisarts op te nemen woor overleg. Indien de patiënt geen huisarts heeft of geen gebruik wil of kan maken van zijn huisarts dient door de Sociaal Psychiatrische Dienst voor een snelle inschrijwing bij een huisartspraktijk zorg te worden gedragen en een daadwerkelijk contact tussen huisarts en patiënt te worden bewerkstelligd. Is het om welke reden dan ook niet mogelijk om een patiënt ingeschreven te krijgen dan dient de Sociaal Psychiatrische Dienst in de persoon van de behandelend of superviserend psychiater deze functie war te nemen totdat een inschrijwing bij een huisarts is te realiseren. In het algemeen kan daarom gesteld worden dat de huisarts de spil dient te zijn in de somatische zorg aan de ambulante chronische psychiatrische patiënt, in nauwe samenwerking met de hulpverlener van de Sociaal Psychiatrische Dienst.

Een uitzondering hierop vormt de somatische zorg die direct voortwloeit uit het voorschrijven van psychofarmaca door de Sociaal Psychiatrische Dienst. De biochemische controle bij het gebruik van psychofarmaca zoals lithiumcarbonat of carbamazepine dient onder de directe verantwoordelijkheid te vallen van de voorschrijwende psychiater van de Sociaal Psychiatrische Dienst. Hij of zij dient direct toegang te hebben tot de daarvoor noodzakelijke faciliteiten. Ook bij de continuiteit van 
zorg aan de chronische psychiatrische patient dient de huppverlener van de Sociaal Psychiatrische Dienst een open oor te houden woor lichamelijke klachten van de patient en de zorg hieromtrent in nauwe samenhang met de hivisarts van de patient te waarborgen. 


\subsection{Bijlagen}

BIJLAGE 1 Ziekten zoals gediagnostiseerd door de internist bij 83 van de 156 onderzochte patiënten

Ziekten

Totaal

1

2

Algemeen

- infectieuze aandoening met sec. anaemie

- bijwerking van medicatic die voorgeschreven is in de juiste dosering.

- late gevolgen van trauma t.h.v. wervelkolom

Tr. Digest

- coloncarcinoom

- carcinoom regio anus/rectum/sigmoid

- hiatus hernia diafragmatica

- hepatomegalie

- steatosis hepatis

- levercirrhose

- slokdarmpathologie

$\mathrm{Tr}$. Circulatorius

- chronische ischaemie hartspier

- cardiale ritmestoornis

- verhoogde bloeddruk

- ongecompliceerde hypertensie

- hypertensie met sec. pathologie

- atherosclerose

- arteriitis temporalis

- M. Raynaud

- phlebitis

- spataderen aan de benen

Tr. Locomotorius

- botcysten

- verworven afwijkingen aan de wervelkolom

- osteoarthritis

- traumatische arthrosis

- frozen shoulder

- osteoporose

Zenuwstelsel

- M. Parkinson

- epillepsie

- neurologische loopstoornissen

- syringomyelie

- carpal tunnel syndroom

Tr. Respiratorius

- chronische bronchitis 


\section{Endocrinologische stoornis}

- micro-adenoom hypofyse

- morbide obesitas

- hyperthyreoidie

- hypothyreoidie

- diabetes mellitus

- insulinoom

- bijnierpathologie

- M. Cushing

Tr. Urogenitalis

- blaasontsteking

- Grawitztumor

- nierstenen

- syphilis

- urovaginale prolaps

$\begin{array}{llll}1 & 1 & 3 & \\ 3 & 1 & & \\ 1 & 1 & & 1 \\ 1 & 3 & & 1 \\ 6 & & & 1 \\ 1 & & & 1 \\ 1 & & & 1 \\ 1 & & 1 & 1 \\ 4 & 1 & 1 & 1 \\ 1 & & & 1 \\ 1 & & & 1 \\ 1 & & & \end{array}$

Huidziekten

- atopische dermatitis/eczeem

- psoriasis

- jeukende huidziekte

$\begin{array}{ll}1 & 1 \\ 1 & 1 \\ 1 & 1\end{array}$

Oogziekten

- glaucoom

- slechte visus t.g.y. org. pathologie

1

$\mathbf{I}=$ reeds bij patiënt bekende diagnosen

$\mathbf{2}$ = nieuw gestelde diagnosen vanuit anamnese, lichamelijk onderzoek en laboratoriumonderzoek

$\mathbf{3}=$ mogelijke diagnosen op basis van anamnese, lichamelijk onderzoek en laboratoriumonderzoek waarvoor aanvullend onderzoek noodzakelijk is. 
BIJLAGE 2

Tabel 1 Afwjkende bevindingen lichamelijk onderzoek bij 83 patiënten

\begin{tabular}{|l|c|}
\hline Bevinding & Aantal \\
\hline verhoogde bloeddruk & 14 \\
overgewicht & 24 \\
huidafwijking & 22 \\
skelet-/gewrichtsaf wijking & 4 \\
afwijking thw hart/bloedvaten & 4 \\
longafwijking & 3 \\
afwijking thv maagdarm kanaal (o.a. palpabel colon) & 13 \\
endocrinologische afwijking & 5 \\
neurologische afwijking & 8 \\
diversen & 5 \\
\hline Total & 102 \\
\hline
\end{tabular}

Tabel 2 Afwijkende laboratoriumtests in totaal en per patiënt

\begin{tabular}{|c|rc|c|}
\hline $\begin{array}{l}\text { aantal afwijkende tests } \\
\text { per patiënt }\end{array}$ & \multicolumn{2}{|l|}{$\begin{array}{c}\text { aantal patiënten } \\
\text { \% }\end{array}$} & $\begin{array}{l}\text { totaal aantal afwijkende } \\
\text { testresultaten }\end{array}$ \\
\hline 0 & 28 & 18 & 0 \\
1 & 46 & 29 & 46 \\
2 & 32 & 21 & 64 \\
3 & 20 & 13 & 60 \\
4 & 14 & 9 & 56 \\
5 & 8 & 5 & 40 \\
6 tot 10 & 8 & 5 & 57 \\
\hline Totaal & 156 & 100 & 323 \\
\hline
\end{tabular}


Tabel 3 AFWIJKENDE TESTUITSLAGEN IN DE KLINISCHE KONTEKST

\begin{tabular}{|c|c|c|c|c|c|c|c|c|}
\hline $\begin{array}{l}\text { Laboratorium } \\
\text { onderzoek }\end{array}$ & $\begin{array}{l}\text { Referentie } \\
\text { waarden }\end{array}$ & 1 & 2 & 3 & 4 & 5 & 6 & \\
\hline BSE & $\left.\begin{array}{l}\mathrm{m} \text { leeftijd/2 } \\
\mathrm{v} \text { leeftijd }+10 / 2\end{array}\right\}$ & 6 & 1 & & 4 & 1 & & \\
\hline $\mathrm{Hb}$ & $\left.\begin{array}{l}\mathrm{m}: 8.5-11.0 \mathrm{mmol} / \mathrm{h} \\
\mathrm{v}: 7.5-10.0 \mathrm{mmol} / \mathrm{l}\end{array}\right\}$ & 2 & & & 2 & & & \\
\hline Ery & $\left.\begin{array}{l}\mathrm{m}: 4.2-5.6 \times 10^{12} / \\
\mathrm{v}: 3.7-5.0 \times 10^{12} \mathrm{n}\end{array}\right\}$ & 2 & & & 2 & & & \\
\hline $\mathrm{Ht}$ & $\mathrm{m}: 0.41-0.51 \mathrm{l} / 1 / 1\}$ & 0 & & & & & & \\
\hline $\begin{array}{r}\text { Indices } \mathrm{MCV} \\
\mathrm{MCH} \\
\mathrm{MCHC}\end{array}$ & $\left.\begin{array}{l}84-104 \mathrm{fl} \\
1,76-2,22 \mathrm{fmol} \\
19,3-23,0 \mathrm{mmol} / 1\end{array}\right\}$ & 6 & & 6 & & & & \\
\hline Leuco & $4,0-10,0 \times 10^{9} / 1$ & 18 & & 17 & & 1 & & \\
\hline $\begin{array}{l}\text { Diff. St.L } \\
\text { Segm.L. } \\
\text { Baso } \\
\text { Eo } \\
\text { Lymfo } \\
\text { Mono }\end{array}$ & $\left.\begin{array}{l}0-4 \\
40-70 \\
0-2 \\
1-6 \\
20-45 \\
2-10\end{array}\right\}$ & 13 & & 10 & 3 & & & \\
\hline Kreatinine & 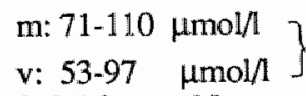 & 4 & 1 & 3 & & & & \\
\hline Kalium & $3,6-5,0 \mathrm{mmol} / \mathrm{l}$ & 6 & & 6 & & & & \\
\hline $\begin{array}{l}\text { Natrium } \\
\text { Chloride }\end{array}$ & $132-142 \mathrm{mmol} / \mathrm{h}$ & 12 & & 11 & & 1 & & \\
\hline $\begin{array}{l}\text { Chloride } \\
\text { Totaal CO2 }\end{array}$ & $96-107 \mathrm{mmol} / \mathrm{i}$ & 8 & & 8 & & & & \\
\hline $\begin{array}{l}\text { Totaal CO2 } \\
\text { Calcium }\end{array}$ & & $\begin{array}{l}9 \\
0\end{array}$ & & 9 & & & & \\
\hline Fosfaat & $\begin{array}{l}2.1-2.6 \mathrm{mmol} / 1 \\
0,90-1,50 \mathrm{mmol} / \mathrm{l}\end{array}$ & 14 & & 13 & & 1 & & \\
\hline Urinezuur & $\left.\begin{array}{l}\mathrm{m}: 0,20-0,42 \mathrm{mmol} / \mathrm{l} \\
\mathrm{v}: 0,12-0,34 \mathrm{mmol} / \mathrm{l}\end{array}\right]$ & $j^{14}$ & & 13 & & & 1 & \\
\hline Alk.fosfatase & $30-125 \mathrm{U} / 1$ & 6 & & 4 & 1 & 1 & & \\
\hline $\begin{array}{l}\text { Y-GT } \\
\text { ASAT (GOT) }\end{array}$ & $\left.\begin{array}{l}<50 \mathrm{U} / 1 \\
\mathrm{~m}:<40 \mathrm{U} / 1 \\
\mathrm{v}:<35 \mathrm{U} /\end{array}\right\}$ & $\begin{array}{r}12 \\
4\end{array}$ & & $\begin{array}{l}8 \\
1\end{array}$ & $\begin{array}{l}2 \\
2\end{array}$ & $\begin{array}{l}1 \\
1\end{array}$ & 1 & \\
\hline ALAT (GPT) & $\left.\begin{array}{l}\mathrm{v}:<35 \mathrm{U} / \mathrm{A} \\
\mathrm{m}:<40 \mathrm{U} / 1 \\
\mathrm{v}:<35 \mathrm{U} / 1\end{array}\right\}$ & 6 & & 3 & 2 & 1 & & \\
\hline $\mathrm{LDH}$ & $200-450 \mathrm{U} / 1$ & 5 & & 4 & 1 & & & \\
\hline Bilirubine (tot) & $<17 \mu \mathrm{mol} / \mathrm{I}$ & $\begin{array}{r}4 \\
54\end{array}$ & & $\begin{array}{c}4 \\
16\end{array}$ & & & & 13 \\
\hline $\begin{array}{l}\text { Cholesterol } \\
\text { Triglyceriden }\end{array}$ & $\begin{array}{l}4,1-6,4 \mathrm{mmol} / \mathrm{l} \\
0,80-1,94 \mathrm{mmol} / 1\end{array}$ & $\begin{array}{l}54 \\
30\end{array}$ & $\begin{array}{l}2 \\
2\end{array}$ & $\begin{array}{l}16 \\
19\end{array}$ & & $\begin{array}{l}1 \\
1\end{array}$ & $\begin{array}{r}22 \\
8\end{array}$ & 13 \\
\hline
\end{tabular}




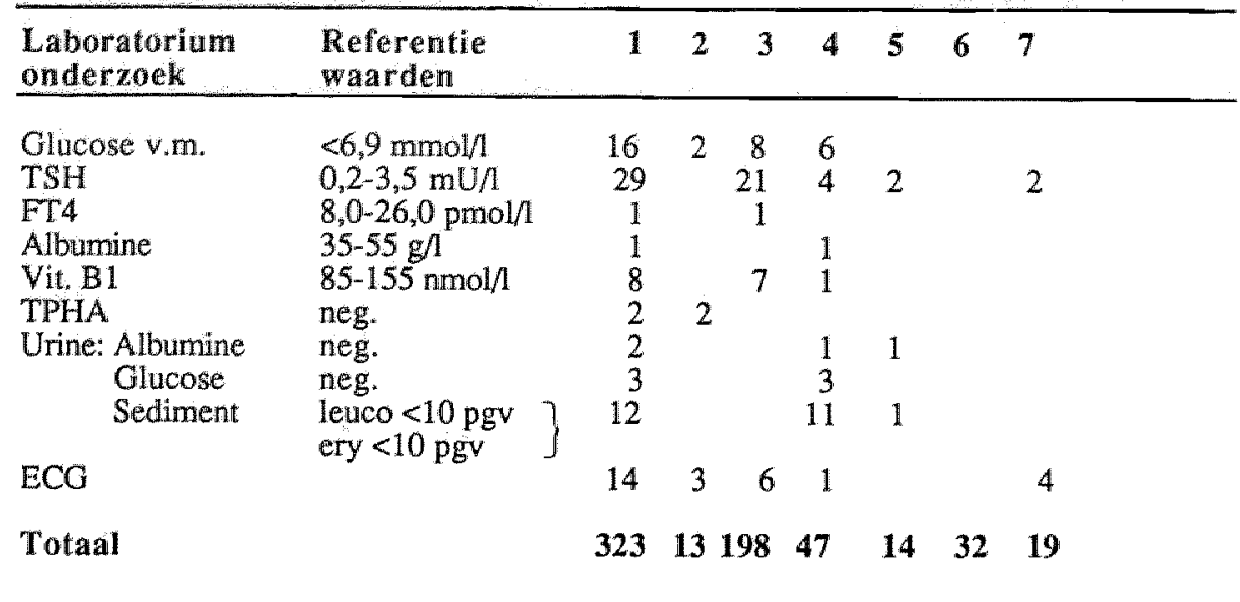

1: In deze kolom zijn alle afwijkingen van de gegeven referentiewaarden, hoe minimaal ook, wermeld.

2: In deze kolom zijn, zover gegevens beschikbaar zijn, de bij de huisarts of specialist reeds bekende afwijkende laboratoriumgegevens weergegeven.

3: In deze kolom zijn klinisch niet relevante afwijkende laboratoriumgegevens vermeld. Het betreft test-uitslagen die minimaal afwijken van de norm, test-uitslagen die tegen de achtergrond van anamnetische gegevens en bevindingen bij lichamelijk onderzoek als niet ter zake doende geinterpreteerd werden.

4: In deze kolom zijn test-uitslagen weergegeven waarvan controle gewenst leek i.v.m. cen mogelijk aanwezige organische aandoening, waarop de kans niet hoog ingeschat werd en de betekenis van de eventuele aandoening als niet van ernstige aard.

5: In deze kolom zijn test-uitslagen weergegeven van 3 patiënten, bij wie met de mogelijkheid van een ernstige organische aandoening duidelijk rekening gehouden werd.

6: In deze kolom zijn laboratoriumuitslagen weergegeven, op grond waarvan aan de patiënten therapeutische adviezen verstrekt werden, met name ten aanzien van dieet en alcoholgebruik.

7: In deze kolom zijn test-uitslagen weergegeven die aanleiding waren tot adviezen voor eventueel medicamenteuze behandeling (hypo- en hyperthyreoïdie, cholesterolverhoging $>8.0 \mathrm{mmol} / \mathrm{l}$, hypertensie). 


\section{ALGEMENE CONCLUSIES EN AANBEVELINGEN}

De studie was gericht op het lichamelijk (on)welbevinden van ambulante chronische psychiatrische patiënten die onder behandeling waren van de Sociaal Psychiatrische Dienst van de RIAGG Maastricht. In totaal waren er 218 patiennten betrokken bij dit onderzoek; 156 patiënten namen uiteindelijk deel aan het gehele onderzoeksprotocol, inclusief een eenmalige lichamelijke keuring door een internist verbonden aan het Academisch Ziekenhuis Maastricht en het opvragen van gegevens over lichamelijke gezondheid bij de eigen huisarts.

Het doel van de studie was de omgang met lichamelijk (on)welbevinden van chronische patiënten door hulpverleners in de ambulante geestelijke gezondheidszorg te verbeteren. Om dit doel te kunnen bereiken werden uit de voornoemde patiëntenpopulatie epidemiologische gegevens verzameld over het vóórkomen, de aard en de miskenning van lichamelijke klachten en ziekten, werden twee methoden onderzocht die het onderkennen van lichamelijke ziekten zouden kunnen vergemakkelijken en werd tenslotte een model ontwikkeld dat zowel de problemen van de patiënt, inclusief het lichamelijk (on)welbevinden ordent, als een samenhang beschrijft tussen de verschillende probleemvelden of nivo's van functioneren van de patiënt.

Op grond van de resultaten uit het epidemiologisch onderzoek bij de beschreven groep ambulante chronische psychiatrische patiënten kan het volgende worden geconcludeerd:

1. De overgrote meerderheid van de patiënten rapporteert lichamelijke klachten.

2. Meer dan driekwart van de patiënten met lichamelijke klachten heeft een functionele stoornis.

3. Afhankelijk van de soort beoordelaar (hulpverlener van de Sociaal Psychiatrische Dienst, huisarts of internist) wordt 30 tot $50 \%$ van de patiënten gediagnostiseerd met een lichamelijke ziekte die of behandeling of verdere medische diagnostiek behoeft. 
4. De overgrote meerderheid zijn eervoudig door de huisarts te behandelen lichamelj]ke ziekten; slechts 4 tot $7 \%$ van de gewonden ziekten wordt beoordeeld als ernstig in de zin van het leven bekortend.

5. De hulpwerlener van de Sociaal Psychiatrische Dienst tesamen met de huisarts van de patient zijn op de hoogte van 9 van de 13 door de internist als levensbekortend gediagnostiseerde ziekten.

6. Geen van de gevonden lifchamelijke ziekten konden als oorzakelijk worden geduid voor her psychiatrisch ziektebeeld.

7. Wanneer miskenning van lichamelijke ziekte wordt gedefinieerd als die niet gediagnostiseerde ziekte waarvan men zeker is dat deze aanwezig is en het leven bekort of een direct corzakelijke relatie heeft met het psychiatrisch ziektebeeld dan wel een direct gevolg is van door de betreffende hulpverlener zelf voorgeschreven medicatie, dan is nosologische miskenning in de onderzochte populatie als gering te beschouwen.

8. De onderzochte groep ambulante chronische psychiatrische patiënten blijkt meer gebruik te maken wan hun huisarts dan de gemiddelde Nederlander.

\section{De relatie tussen lichamelijke klachten van de patiënt en gevonden} lichamelijke ziekten en de relatie tussen overeenstemming van patiënt en hulpverlener over lichamelijk welbevinden van de patiënt en gevonden lichamelijke ziekten:

1. de resultaten van een door de patiënt zelf in te wullen klachtenlijst over lichamelijk onwelbevinden vertonen geen samenhang met ziekten gediagnostiseerd door de huisarts van de patiënt of de internist die een eenmalige keuring verricht;

2. het concept overeenstermming tussen patiënt en hulpverlener over het lichamelijk (on)welbevinden van de patiënt geeft een grotere kans om lichamelijke ziekten in te schatten zoals de huisarts van de patiënt of een internist die een eenmallige keuring verricht dat zou doen, vindt enige steun in het door ons verrichte onderzoek.

\section{Aanbevelingen:}

1. Om overzicht te krijgen over de vaak complexe problematiek van de ambulante chronische psychiatrische patiènt is het noodzakelijk ordening aan te brengen in de aangeboden problemariek en samenhang tussen de verschillende probleemvelden te signaleren. Het klassieke medische model is hiervoor niet geschikt. Het toepassen van een op het systeemmodel geënt model voorziet in de noodzakelijke ordening en samenhang waardoor een rationeel behandelingsplan kan worden opgesteld. 
2. Het verdient aanbeveling om in de dagelijkse social psychiatrische praktijk na te gaan of de patiënt gebruik maakt van de diensten van zijn/haar huisants.

3. In geval een ambulante chronische psychiatrische patient geen gebriik makakt van de diensten van een huisarts of niet ingeschreven staat bij een huisarts dient de hulpverlener van de geestelijke gezondheidszorg te voorzien in deze lacune.

4. Voor een adequate inventarisatie en behandeling van lichamelijke problemen van de patiënt is een nauwe samenwerking tussen de hulpverlener van de Sociaaal Psychiatrische Dienst en de huisarts van de patiënt van doorslaggevende betekenis.

5. Een Sociaal Psychiatrische Dienst dient te beschikken over een goed geoutilleerde onderzoeksruimte om patiënten zo nodig adequaat lichamelijk te kunnen onderzoeken.

6. Psychiaters die psychofarmaca voorschrijven dienen direct toegang te hebben tot die laboratoriumfaciliteiten die noodzakelijk zijn om de werkingen en bijwerkingen van de door hen voorgeschreven medicamenten te kunnen beoordelen.

7. De in het onderzoek gevonden percentages "miskenning" van lichamelijke ziekten vormen geen aanleiding om routinematig elke ambulante chronische psychiatrische patiënt lichamelijk te onderzoeken. 


\section{GENERAL CONCLUSIONS AND IMPLICATIONS}

This thesis is focused on the physical well-being of chronic community psychiatric patients being treated at an urban community psychiatric service (RIAGG-Maastricht) between 1986 and 1987 . A total of 218 patients met the criteria for chronicity as defined in this study. Of these, 156 participated in the complete investigation, which included a physical check-up by a specialist in internal medicine at the local university hospital (Academisch Zuekenhuis Mastricht) and the obtaining of medical information of the patient's own general practitioner.

The aim of this study was to improve the monitoring and care of physical health of chronic patients by therapists working in a community psychiatric setting.

To this end epidemiological data were collected from the above sample on the prevalence, nature, and misdiagnosing of physical complaints and diseases. In addition, two methods were tested for their ability to facilitate the detection of physical disease. Finally, a practical model was developed by which problems of chronic community psychiatric patients, including their physical well-being, can be compiled methodically and relationships between various problem areas of the patient discriminated.

Based on the results of the epidemiological part of the study the following conclusions can be drawn:

1. The overall majority of patients report physical complaints.

2. More than three-quarters of the patients with physical complaints are diagnosed as having a functional disorder.

3. Thirty percent of the patients are diagnosed by the patients community psychiatric unit therapist and general practitioner as having a physical disease that warrants further medical attention; the screening specialist in internal medicine diagnoses $50 \%$ of the patients with one or more physical disease. 
4. The majority of the physical diseases detected can easily be treated by a general practitioner, only $4 \%-7 \%$ of the physical diseases detected are so severe that they may be considered as probably shortening life.

5. The community psychiatric unit therapist, together with the patient's general practitioner, are aware of 9 out of 13 physical diseases labelled by the specialist in internal medicine as probably shortening life.

6. None of the physical diseases diagnosed had a causal relationship to the psychiatric disorder.

7. If one defines missed physical diagnoses as clearly present diseases that have not been noticed and are probably shortening life or are either directly related to the psychiatric disease or a direct consequence of medication prescribed by the therapist of the community psychiatric unit, unnoticed physical disease in our research population is scarce.

8. The population of chronic community psychiatric patients who participated in this study visit their general practitioner more frequently than the average inhabitant of the Netherlands.

The relationship between physical complaints and diagnosed physical diseases and the relationship between patient/therapist consensus regarding the physical health of the patient and diagnosed physical disease reveal that:

1. the results of a self-report questionnaire on physical well-being do not correlate with physical diseases as diagnosed by the patient's general practitioner or the screening specialist in internal medicine, and that

2. the hypothesis that consensus between patient and therapist regarding the physical well-being of the patient increases the therapist's chance of diagnosing physical disease more along the lines of the patient's general practitioner or of the screening specialist in internal medicine is supported by our research data.

\section{Implications}

1. In order to have an overview of the often complex problems of chronic community psychiatric patients, it is neccessary to structure the presenting problems systematically and to discriminate relationships between the various problem areas. The classical medical model falls short in this setting. A systematic model 
provides the necessary structure and cohesion of problem areas upon which a rational rehabilitation plan can be established.

2. In caring for the physical needs of chronic community psychiatric patients, it is important to know whether the patient is availing him/herself of the services of a general practitioner.

3. If a chronic community psychiatric patient is not capable of availing him/herself of the services of a general practitioner, a community psychiatric unit should be able to provide these services.

4. In order to be able to screen and treat physical disease of the patient adequately, close cooperation between the community psychiatric unit therapist and the patient"s general practitioner is essential.

5. Community psychiatric units need to be equipped with adequate physical screening facilities in order to be able to screen physical disease, independent from other services.

6. Psychiatrists who prescribe psychotropic medication should have direct access to laboratory facilities that can monitor the effects of the prescribed medication.

7. The quantity and quality of undiagnosed physical disease in our population does not wartant an extensive routine and standardized physical screening procedure. 


\section{SAMENVATTING}

Dit proefschrift heeft als centraal thema de verbetering van de omgang met lichamelijke klachten en ziekten in de ambulante behandeling van chronische psychiatrische patiënten. Hiertoe wordt allereerst verslag gedaan van een uitgebreid literatururonderzoek. Daarna worden van de populatie ambulante chronische psychiatrische patiënten van de Social Psychiatrische Dienst van de RIAGG Maastricht epidemiologische gegevens verzameld ter bepaling van de omvang en ernst van lichamelijke klachten en ziekten, alsook de mate waarin hulpverleners in de ambulante zorg lichamelijke klachten en ziekten herkennèn. Vervolgens wordt de ontwikkeling van een hulpinstrument beschreven, bestemd om de vaak complexe problemen van chronische psychiatrische patiënten te kunnen inventariseren en ordenen alsook de samenhang tussen de verschillende probleemgebieden te kunnen signaleren. De rol van lichamelijke klachten en ziekten binnen de algehele problematiek van de patiënt kon door middel van dit hulpinstrument onderkend worden en daarmee aanknopingspunten geven voor een ambulant behandelingsplan. Als laatste wordt een tweetal methoden onderzocht die ook niet medisch geschoolde hulpverleners van dienst zouden kunnen zijn bij het herkennen van lichamelijke klachten en ziekten van hun patiënten. Deze methoden hebben betrekking op de hoeveelheid lichamelijke klachten en het eens zijn van hulpvrager en hulpverlener over de lichamelijke gezondheidstoestand van de hulpvrager.

Lichamelijke klachten kunnen door velerlei redenen ontstaan. Een veelheid aan klachten en dysfuncties van veelal psychologische en sociaal maatschappelijke aard kunnen de aandacht voor een adequate evaluatie en behandeling van lichamelijke klachten doen verminderen. Een vroegtijdige herkenning van lichamelijke ziekten kan de stabiliteit van ambulante chronische psychiatrische patiênten bevorderen en daarmee opname voorkomend werken. Een hechte samenwerking van de Sociaal Psychiatrische Dienst met de eerstelijns gezondheidszorg is een onontbeerlijk element in een adequate somatische hulpverlening voor deze patiëntengroep.

De dissertatie is opgebouwd uit twee onderdelen:

naast een inleiding en conclusie (respectievelijk hoofstuk 1 en 8), bestaat dit proefschrift uit een zestal artikelen (hoofdstuk $2 \mathrm{v} / \mathrm{m} 7$ ). 
In de inleiding word het te onderzocken probleemgebied afgebakend en worden het doel van dit promotieonderzoek alsook de middelen om dit doel te bereiken aangegeven. In de uilleilding worden gestelde onderzoeksvragen beantwoord en aanbevelingen gedaan om de omgang met lichamelijke klachten en ziekten te verbeteren.

De zes artikelen zijn het directe product van de in de inleiding opgeworpen onderzoekswragem; in elk artikel wordt de achtergrond van een van de gestelde vragen belicht en een antwoord geformuleerd. Voor deze opzet is gekozen om de bevindingen aan cen zo breed mogelijk forum aan te kunnen bieden.

In hoofdstuk 1 worden aan de hand van een ziektegeschiedenis de problemen in de herkenning en omgang met lichamelijke klachten en ziekten geillustreerd. Een vijftal onderzoeksyragen wordt geformuleerd met als doel de ontwikkeling van een omgang met lichamelijke klachten en ziekten van de chronische psychiatrische patient in de ambulante sociaal psychiatrische praktijk.

De vijf geformuleerde onderzoekswragen zijn:

1. Hoe kan lichamelijk onwelbevinden worden onderkend uit de vele problemen wan de ambulante chronische psychiatrische patiënt?

2. Wat is de aard, ernst en omvang van lichamelijke klachten en ziekten bij ambulante chronische psychiatrische patiënten?

3. Hoe vaak wordt bij de ambulante chronische psychiatrische patiënt lichamelijke ziekte miskend?

4. Is het mogelijk om een eenvoudig hulpinstrument te ontwikkelen om lichamelijke ziekten op te sporen bij ambulante chronische psychiatrische patienten; een instrument dat gehanteerd kan worden door ook niet strikt medische disciplines?

5. Wat is de samenhang tussen lichamelijk onwelbevinden en onwelbevinden op andere probleemgebieden van de ambulante chronische psychiatrische patient?

Elke onderzoekswraag wordt vervolgens uitgewerkt. Relevante theoretische aspecten inclusief literatuur onderzoek worden besproken. Deze gegevens worden zo mogelijk gekoppeld aan de dagelijkse sociaal psychiatrische praktijk door middel van de eerder genoemde ziektegeschiedenis of door middel van een explorerend vooronderzoek. 
Op de eerste onderzoeksvraag. "Hoe kan lichamelijk owwetbewinden worden ondentend wit de vele problemen wan de ambulante chronische psychatrische patent? antwoord een wijze van inventarisatie geformuleerd, genaand de probleemanalyse. Dit hulpinstrument wordt beschreven in hoofdstuk 2: "Probleemanalyse als onderdeel wan de omgang met chronische psychiatrische patièten in de ambulante geestelijke gezondheidszorg". De probleemanalyse is geënt op de systeemtheorie en onderseheidt vier probleemgebieden of nivo's van functioneren van de patiènt. Daamaast wordt in de probleemanalyse de hulpverleningsgeschiedenis en de competentie van de patient en zijn omgeving geinventariseerd. De probleemanalyse is een handleiding voor hulpverleners in de sociaal psychiatrische praktijk om tot een systematische informatieverzameling wan patiëntengegevens te komen. De op deze wijze verkregen ordening biedt de hulpverlener structuur aan in een ogenschijnlijke chaos rond de patiênt. Deze wijze van waamemen stimuleert tot gerichter kijken naar en beoordelen van de aangeboden problematiek, met name ten aanzien van probleemgebieden waar voorheen geen of onvoldoende andacht voor was. Lichamelijke klachten en zieken zijn een voorbeeld van een dergelijk vaak verwaarloosd probleemgebied. Daarnaast levert de probleemanalyse een schat aan informatie op die bruikbaar is om onze kennis over en onze professionele omgang met de chronische psychiatrische patiënt te vergroten.

In hoofdstuk 3, "Miskend of ontkend probleemgebied, somatische aandoeningen bij ambulante chronische psychiatrische patiënten", wordt aan de hand van literatuuronderzoek de incidentie van somatische problematiek in de psychiatrie geschetst alsook de vaak gebrekkige omgang ermee, speciaal in de ambulante geestelijke gezondheidszorg. Aan de hand van een pilotstudy wordt duidelijk dat lichamelijke klachten en ziekten ook in de Maastrichtse Sociaal Psychiatrische Dienst (SPD) in aanzienlijke mate aanwezig zijn. Door middel van een viertal casus word de rol beschreven die lichamelijke klachten en ziekten in het gehele dysfunctioneren van ambulante chronische psychiatrische patiënten kunnen spelen. Tevens wordt een onderzoek aangekondigd dat, door middel van het verzamelen van epidemiologische gegevens over lichamelijke klachten en ziekten nast factoren die miskenning ervan kunnen bevorderen, gericht is op het ontwikkelen van een in de sociaal psychiatrische praktijk bruikbaar protocol voor de omgang met somatische klachten en afwijkingen van chronische patiënten.

In hoofdstuk 4, "Het lichamelijk welbevinden van ambulante chronische psychiatrische patiënten, een onderzoeksprotocol", worden kritische kanttekeningen geplaatst bij de tot op heden gebruikte onderzoeksmethoden ter opsporing en benoeming van lichamelijke 
ziekten bif psychiatrische patuénten. Met name de definiering van wat onder lichamelijk ziek zijn en wat onder miskenning van lichamelijke ziekten kan worden verstaan, wordt hierin axin de orde gesteld. Er wordt beschreven aan welke criteria onderzoek op dit grebied zou moeten voldoen om een zo evenwichtig mogelijk beeld te geven van de omvang en enst van somatiek in de sociale psychiatrie..

In hoofdstuk 5, "Lichamelijke ziekten in een ambulante praktijk voor chronische psychiatrische patięnten: behandelingsconsequenties", worden de uitkomsten van het in de vorige twee hoofdstukken aangekondigde onderzoek beschreven. In dit onderzoek wordt voor eers oordeel over het lichamelijk welbewinden van de patiënten gebruik gemaakt van twee niet bij de Sociaal Psychiatrische Dienst werkzame medici: de huisarts van de participerende patiënt (door middel van een vragenlijst) en een internist die een routine internistisch onderzoek volgens vast protocol witvoent bij alle participerende patiënten.

Met name wordt een antwoord gegeven op de tweede onderzoeksvraag omtrent de aard, ernst en omvang van lichamelijke klachten en ziekten bij ambulante chronische psychiatrische patiënten, in dit geval onder behandeling van een Sociaal Psychiatrische Dienst van een middelgrote stad. De uitkomsten van dit onderzoek bevestigen eerdere publikaties over de aard van lichamelijke ziekten. Slechts $14 \%$ van de voor het onderzoek in aanmerking komende patiënten weigerden hun medewerking; een opvallend laag percentage in vergelijking met eerdere studies. De ernst van de gevonden lichamelijke ziekten blijkt althans in onze populatie mee te vallen. Ook blijkt dat vrijwel alle aan het onderzoek participerende patiënten regelmatig hun huisarts bezoeken. Huisarts en hulpverlener wan een Sociaal Psychiatrische Dienst blijiken gezamenlijk op de hoogte van het merendeel van de door de keurende internist als ernstig gediagnostiseerde ziekten. Gekoppeld aan de uitkomsten van dit onderzoek worden aanbevelingen gedaan voor de accuratere omgang met lichamelijke klachten en ziekten.

In hoofdstuk 6 en 7 worden twee methoden onderzocht om te komen tot een eenvoudige wijze van somatische screening; een screening die ook hanteerbaar is voor niet medisch geschoolde hulpverleners van een Sociaal Psychiatrische Dienst. Het gebruik van een klachtenlijst, de Hopkins Symptom Checklist, blijkt niet te voldoen als een screeningsinstrument voor dit doel; dit in tegenstelling tot overeenstemming tussen patient en hulpverlener.

In hoofdstuk 6 "Herkenning van lichamelijke ziekten bij ambulante chronische psychiatrische patiënten met behulp van klachtenlijst", werd een internationaal 
gebruikelijke en ook in Nederland gevalideerde somatische klachtenlijst, de Hopkins Symptom Check List, woor dit doel onderzocht. Alle participerende patienten vulden deze klachtenlijst in op de dag van de keuring. De scores op deze lijst werden onderzocht op hun voorspellende waarde woor het onderkemnen van lichamelijke zlekten. Als referentie werd de mening hieromtrent van zowel huisarts als keurend internist genomen. Deze lijst bleek geen enkele voorspellende waarde te hebben in het onderkennen van lichamelijke ziekten.

In hoofdstuk 7, " De invloed van overeenstemming op het herkennen van lichamelijke ziekten bij ambulante chronische psychiatrische patiënten", wordt een voor dit doel in de somatische geneeskunde nogal ongebruikelijke variabele onderzocht, namelijk een dynamische component van de therapeut/patiënt relatie. In dit artikel wordt de veronderstelling geponeerd dat overeenstemming (inhoudelijke overeenstemming en wederzijds begrip) tussen patiènt en hulpverlener van de Sociaal Psychiatrische Dienst over de lichamelijke gezondheidstoestand van de patiënt, de kans vergroot dat de hulpverlener lichamelijke ziekten meer in zal schatten zoals een externe medicus dat zal doen. Deze hypothese wordt getoetst in de eerder beschreven onderzoekspopulatie door middel van een speciaal voor dit doel ontworpen vragenlijst. De mening van de hulpverlener van de Sociaal Psychiatrische Dienst over lichamelijke ziekten van de patiënten in zowel de groep met overeenstemming als die waarin geen overeenstemming bestaat wordt vergeleken met de mening van twee externe medici, namelijk de huisarts van de patiënt en de keurende internist.

De uitkomsten van dit onderzoek lijken steun te geven aan de hypothese. Het aantal patiënten was echter te klein om een definitieve relatie tussen overeenstemming en inschatting van lichamelijke ziekten aan te kunnen geven. Ook geven de data aan dat deze methode wan inschatting van lichamelijke ziekten niet voor alle categoriedn chronische psychiatrische patienten van toepassing is. Bevestiging van deze hypothese zou een aanzienijke steun kunnen zijn bij de beoordeling van de aanwezigheid wan somatick in de dagelijkse sociaal psychiatrische praktijk.

In hoofdstuk 8 worden de bevindingen van dit promotieonderzoek geordend en van kommentaar voorzien. De ziektegeschiedenis uit het eerste hoofdstuk wordt daarbij als leidraad gebruikt. Het begrip miskenning van ziekten wordt nader uitgewerkt. Een begrip dat de basis vormt voor de derde onderzoeksvraag naar de frequentie van miskenning van lichamelijke ziekten in de onderzoekspopulatie wordt nader uitgewerkt. Op de eerder genoemde casus wordt de probleemanalyse toegepast en wordt tevens aangegeven hoe 
door middel van de aan de probleemanalyse ten grondslag liggende systeemtheorie een voor de praktijk bruikbaar antwoord te formuleren is op de laatste onderzoeksvraag naar de samenhang tussen lichamelijk welbevinden en onwelbevinden op andere probleerngebieden van de ambulante chronische psychiatrische patiënt.

In hoofdstuk 9 worden de voornaamste conclusies samengevat en aanbevelingen gedaan om tot een rationelere en effectievere omgang van hulpverleners van een Sociaal Psychiatrische Dienst met lichameljike klachten en ziekten te komen in de ambulante hulpverlening aan chronische psychiatrische patiënten. 


\section{SUMMARY}

The central theme of this thesis is the improvement of the monitoring and care of the physical health of chronic psychiatric patients in the community.

First, of all the relevant literature is examined critically. Next, epidemiological data are presented regarding the quantity and severity of physical symptoms and diseases of our own chronic psychiatric patients, as well as the extent to which community psychiatric therapists are aware of physical complaints and diseases of their patients. In a separate chapter, the development of a treatment-oriented instrament that allows one to compile information on chronic patients and their systems, as well as to relate various problems to one another, is described and discussed. The role of physical complaints and diseases within the whole field of signs and symptoms surrounding the identified patient can be outlined using this instrument, leading to a well-documented and rational integration of somatic dysfunction in the form of a rehabilitation plan. Finally, two methods are tested for their ability to discriminate patients with severe physical problems who warrant further medical attention. These tested methods, a physical complaint questionnaire and mutual agreement/understanding between patient and therapist on the presence of physical disease in the patient, may also help non-medical personnel working in a community psychiatric unit to recognize physical complaints and disease in their patients.

Physical complaints may arise for any number of reasons. A multitude of complaints and dysfunction of both psychological and social origin may divert the therapist's attention and result in a less than adequate evaluation of the patient's physical complaints and signs. Early recognition and treatment of physical diseases may well enhance the stability of chronic community psychiatric patients and reduce the need for admission or readmission to the hospital. Close cooperation between community-based psychiatric therapists and such community-based physicians as general practitioners is vital for providing this patient population with adequate somatic care. 
This thesis consists, in essence, of two main parts. The first part uncludes an introduction (chapter 1) and conclusion (chapter 8); the second is made up of six papers (chapters 27). In the introduction, the relevance of ineluding the monitoring of physical health in the care of chronic psychiatric patients in the community is explained. The goals of this thesis, and the means for attaining them, are also presented. In the concluding chapter, the research questions raised in the first chapter are answered, and recommendations for improving the quality of somatic monitoring in community psychiatric care are given.

The six papers included in this dissertation answer the research questions raised in the introduction. As such, each one highlights the reasons for asking one of these questions and formulates an answer to it. In order to make the results of this research available to the widest possible audience, the decision was made to write parts of this thesis in article form. These articles have been accepted by various journals and some have already been publisshed.

In chapter 1, the problems of providing adequate somatic monitoring in daily practice is highlighted by means of a case history. Five research questions are formulated, answers to which are intended to facilitate the development of a monitoring procedure for the physical complaints and diseases of chronic psychiatric patients, specifically in an ambulatory setting.

These questions are:

1. How can physical complaints and diseases be discriminated from the many problems of the chronic community psychiatric patient?

2. What is the nature, severity and prevalence of physical complaints and diseases in chronic community psychiatric patients?

3. How often do physical diseases go undiagnosed in chronic community psychiatric patients?

4. Is it possible to develop a simple screening instrument for physical diseases in chromic community psychiatric patients, an instrument that can also be used by non-medical personnel?

5. What is the relationship between the physical and non-physical well-being of the chronic community psychiatric patien? 
Each of these questions is discussed in detail. Relevant theoretical aspects, including a literature review, are presented and commented on. These comments are either based on current daily community psychiatric care and illustrated by the case history mentioned earlier or based on a pilot study in our own community psychiatric unit.

A systematic problem inventory (problem analysis), developed in response to the first research question, is described in chapter 2, "Problem analysis: an instrument in the rehabilitation of chronic psychiatric patients in the community". The problem analysis is founded on the general system theory and discriminates four problem areas or levels of functioning of the patient. The patient"s previous psychiatric history and coping strategies are also taken in account. For community psychiatric therapists, the problem analysis compiles information on chronic patients and their symptoms in a systemic manner. Order is thereby created in the seeming chaos that surrounds the patient. This systematic approach enables the therapist to focus his/her attention on problem areas of the patient that were previously not recognized, such as physical complaints and diseases. Furthermore, the problem analysis stimulates more professional, rational, and reproducible care for chronic community psychiatric patients.

In chapter 3, "Somatic dysfunctioning of chronic psychiatric patients living in the community", physical problems in psychiatry are presented in the form of a literature review. The often ineffective strategies for dealing with physical complaints and symptoms, especially in community psychiatry, are discussed here. A pilot study in the community psychiatric unit of the Community Psychiatric Service (RIAGG) of Maastricht, the Netherlands indicates the considerable number of physical complaints and diseases in chronic patients. The role that physical complaints and diseases can play in the overall functioning of chronic community psychiatric patients is illustrated in four case histories. The data derived from the pilot study provided the impetus for the development of a research project aimed at developing a protocol for the monitoring of physical health in community psychiatry. To this end, epidemiological data on the presence of plyysical complaints and diseases, as well as factors that contribute to physical diseases going undiagnosed, were studied in chronic patients currently being treated at our local community psychiatric unit.

In chapter 4, "Physical illness in the chronic community psychiatric patient" a critical review", research methods currently used in the detection and definition of physical disease are examined. The absence of a clear definition of physical disease and what a missed diagnosis entails are discussed. Basic research criteria are proposed to relate data 
to current psychatric practice, as is the notion that the high percentages of physical disease that are so often quoted might not only reflect inadequate care but also an attempt to promote the classic medical model in community psychiatry.

In chapter 5, "Physical illness in chronic psychiatric patients from a community psychiatric unit: the implications for daily practice ${ }^{\text {t1 }}$, results of the research protocol and project proposed and described in the previous chapters are discussed. In addition to the physical diagnosis given by the patient's community psychiatric therapist, the opinions of both the patient"s general practitioner and a specialist in internal medicine, who screened all patients using a set protocol, are sought. The research project provided an answer to the second research question on the nature, severity and prevalence of physical complaints and diseases in chronic psychiatric patients currently being treated at an urban community psychiatric unit. These data confirm earlier reports on the nature of physical diseases. Only $14 \%$ of the patients selected declined a medical evaluation; this is a considerably lower percentage than that given in earlier reports. The severity of the detected physical diseases in our population was far less than expected. Eighty-seven percent of the participating patients visited their general practitioner regularly. The patient's general practitioner and the community psychiatric therapist, together, were aware of the majority of severe physical diseases found by the screening specialist in internal medicine. The research data described in this paper imply that there is a need for close cooperation between community psychiatric therapists and primary care physicians. In order to meet the somatic needs of chronic patients in community psychiatric care, a more accurate monitoring of health care-seeking behavior of the patient is neccessary.

In chapter 6 and 7, two methods are tested for their ability to discriminate physical disease. The first variable is a complaint questionnaire, the second, consensus between patient and therapist as to the physical well-being of the patient.

In chapter 6, "Detecting physical disease by questionnaire in chronic community psychiatric patients", the Hopkins Symptom Checklist (HSCL), a self-report scoring list of physical symptoms that is well established internationally and validated in the Netherlands, is tested for its ability to screen physical disease. All participants completed this questionnaire on the day they were physically screened by the specialist in internal medicine. The HSCL scores were analyzed and correlated with the opinion of the patient"s general practitioner as well as with that of the screening specialist on the presence of physical disease. Demographic, social, and psychological traits affecting the HSCL scores were also analyzed. The HSCL was not able to discriminate physical 
disease and should therefore not be used as a routine screening instrument in this population. Physical complaints are nearly always present in this patient group but do not appear to refer specifically to physical disease.

In chapter 7, "The influence of consensus on the assessment of physical disease in chronic community psychiatric patients", a rather unusual variable in screening physical disease is investigated: consensus, a dynamic construct of a patient/therapist relationship. In this chapter, it is argued that consensus (i.e. agreement and mutual understanding) between patient and therapist on the physical well-being of the patient may increase the accuracy with which a community psychiatric therapist, irrespective of his/her discipline, assesses physical disease in the patient. This hypothesis is tested in the patient population described earlier by means of a specially developed set of questionnaires. The community psychiatric therapist's assessment of physical disease in both the consensus and no consensus group is compared with those of two external medical observers, the patient's general practitioner and a screening specialist in internal medicine. The results tend to support the proposed hypothesis. Replication of this study using a larger sample is recommended in order to confirm the value of consensus in the assessment of physical disease in at least some subgroups of chronic ambulatory psychiatric patients, as consensus could have implications for the management of physical signs and symptoms in daily community psychiatric practice.

In chapter 8 , the results of the research project are evaluated and conclusions are drawn. The case history described in the first chapter is used to illustrate the problems of somatic screening in daily practice. In this chapter the definition of a missed physical diagnosis is discussed. Such a discussion is essential in order to answer the third research question on the frequency of a missed physical diagnosis in chronic community psychiatric patients. A community psychiatric assessment is given on the introductory case history using the problem analysis. Special reference is made to the last research question on the relationship of the physical and non-physical well-being of chronic community psychiatric patients.

In chapter 9, general conclusions are drawn and implications are made for a more rational and effective monitoring of physical complaints and diseases in community care of chronic psychiatric patients. 


\section{REFERENTIES}

Adler O., Helplessness in the helpers, Britush Joumal of Psychology, 45, 315-326, 1972

Adler D.A., The medical model and psychiatry's tasks, Hospital and Community Psychiatry, 6, 387-392, 1981

Adlet D.A.* Drake R.E., Stern R., Viewing chronic mental illiness: a conceptual framework, Comprehensive Psychiatry, 25, 2; 192-207, 1984

Ananith J., Physical illness and psychiatric disorders, Comprehensive Psychiatry, 25, 6, 586-593, 1984

Babigian H.M., Odorolf CL., The mortality experience of a population with psychiatric illness, American Journal of Psychiatry, 126,470-480, 1969

Bachrach L.L., Planning services for chronically mentally ill patients, Bulletin of the Menninger Clinic, $47.163-188,1983$

Bachrach L.L., Defining chronic mental illness: a concept paper, Hospital and Community Psychiatry, $39,4,383-388,1988$

Barnes R.F., Mason J.C., Greer C., Ray F.T. "Medicall illness in chronic psychiatric outpatients, General Hospital Psychiatry, 5, 191-195, 1983

Beresford T.P., Hall R.C.W., Wilson F.C., Blow F., Clinical laboratory data in psychiatric outpatients, Psychosomatics, 26, 9, 731-744, 1985

Bertalanffy L. von, An outline of general system theory, British Journal of Philosophy of Science, 134- 165,1950

Boeckhorst $F$., Observatie en analyse van triadische interactiepatronen in gezinnen, Tijdschrift voor Psychotherapie, 6, 3, 140-148, 1980

Brown G.W., Harris T., Social origins of depression, Travistock Publications London, 1978

Clare A., Psychiatry in dissent, Travistock Publications London, 1976

Cleghorn J., Levin S, "Training family therapists by setting learning objectives, American Journal of Orthopsychiatry, 43,3,439-446, 1973

Dalle van, Groot Woordenboek der Nederlandse Taal, lle druk, Utrech//Antwerpen, 1985

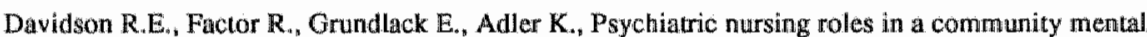
health center, Community Mental Health Journal, 24, 83-86, 1988

Department of Science, Public Health and Culture, Statement on mental health, 1984

Derogatis L.R., Lipman R.S., Rickels K., Uhlenthuth E.H., Covi L., The Hopkins Symptom Checklist, At self-report symptom inventory, Behavioral Sciences, 19, 1-15, 1974

Dingwwall J.M., Psychiatric Rehabilitation, Bulletin of the Royal College of Psychiatrists, 11, 158-160, 1987

Dormaar M., Dijkman C.I.M., de Vries M.W., Psychotherapeutic outcome: measuring reliable clinical change, Psychotherapy and Psychosomatics, 50,95-101, 1988

Dubos R., Man, medicine and environment, Pall Mall Press London, 1968 
Eastwood M.R. Trevelyan M.H., Relationship between physical and psychiatric disorder, Psychological Medicine, 2, 363-372, 1972

Engel G.L., The need for a new medical model: a challenge for biomedicine, Science, 196, 129-136, 1977

Engel G.L., The clinical application of the biopsychosocial model, American Joumal of Psychiatry, 137, $5,535-544,1980$

Erickson G.D., The concept of personal network in clinical practice, Familly Process, $14,4,487-496,1$ 975

Erickson E.H., Childhood and society, W.W. Norton \& Co. New York, 1963

Es J.C. van, Patiënt en huisarts, een leerbnek huisartsgeneeskunde, Oosthoek, Scheltema en Holkema, Utrecht, 1974

Fleiss J.L., Statistical methods for rates and proportions, New York, Wiley, 1973

Freud S., The dynamics of transference, J. Strachey (ed.), Standard Edition of the compllete works of Sigmund Freud, 12, 99-108, London, Hogarth, 1912-1958

Giel R., Dijk S., Weerden-Dijkstra J.R., Mortality of the long-stay population of all Dutch mental hospitals, Acta Psychiatrica Scandinavica, 57, 3611-368, 1978

Greenson R.R., Wexler M., The nontransference relationship in the psychoanalytic situation, In: Explorations in psychoanalysis, 359-386, Incemational Universities Press, New York, 1978

Guze S.B., Nature of psychiatric illness: Why psychiatry is a branch of medicine, Comprehensive Psychiatry, 4, 295-307, 1978

Haley J., Uncommon therapy, In The psychiatric techniques of Milton H. Erickson, New York, Norton \& Cy, 1973

Hall R.C.W., Popkin M.K., Devaul R.A., Faillace L.A., Stickney S.K., Physical illness presenting as psychiatric disease, Archives of General Psychiatry, 35, 1315-1320, 1978

Hall R.C.W., Gardner E.R., Stickney S.K., LeCann A.F., Popkin M.K., Physical illness manifesting as psychiatric disease, Archives of General Psychiatry, 37, 989-995, 1980

Hampton J.R., Harrison M.J.G., Mitchell J.R.A., Prichard J.S., Seymour C., Relative contributions of history-taking, physical examination and laboratory investigation to diagmosis and managernemt. of medical outpatients, British Medical Journal, 2, 486-489, 1975

Horfman R.S., Koran L.M., Detecting physical illness in patients with mental disorders, Psychosomatics, 25: 9, 654-660, 1984.

Honig A., Radistake S., Romme M.A.J., Breuls M.G.G.J., Problem analysis: an instrument in the rehabilitation of chronic Psychiatric patients in the community, The International Journal of Social Psychiatry, 33, 4, 303-311, 1987

Honig A., Escher A.D.M.A.C., Romme M.A.J., Breuls M.G.G.J., Miskend of ontkend probleemgebied. Somatische aandoeningen bij ambulante chronische psychiatrische patienten, Tijdschrift voor Psychiatrie, 28, 10, 676-686, 1986 
Honig A., Pop P. Escher A.D.M.A.C., Philipsen H, Romme M.AJ., Het lichamelijk welbevinden wan ambilante chronische psychiatrische patienten. Een onderateksprotocol, Tijdschrift voor Sociale Gezondheidstorg, $66,181-184,1988$

Honig A. Pop P., Tan E.S., Philipsen H. Romme M.A.J., Physical illness in chronic psychiatric patients from a community psychatric unit: the implications for daily practice, British Journal of Psychiatry, $155,58-64,1989$

Hoogdinin C.A.L en Haan E. de, Ambulante behandeling wan emstige psychiatrische patiẽnten, Maridblad Geestelijke Volksgezondheid, 11, 752-760, 1979

Hoogdwin C.A.L., Haan E. de. Terluin B., Somatische aandoeningen bij opgenomen psychiatrische patienten. Tüjdschrift voor Psychiatrie 27, 2, 105-114, 1985

House of Commons Social Service Committee; Second report from the session 1984/5-Community Care, 1, Lrondon, HMSO, 1985

Intagliated $J_{n}$ Baker $F_{* *}$ Factors affecting case management services for the chronically mentally ill, Administration in Mental Health, 11, 2, 1983

Jansen $A_{u}$, Merkelbach $H_{\text {. }}$, De wens is de vader van de gedachte, De Psycholoog, 23, 41-44, 1988

Kampmeier M.H., Diagnosis and treaument of physical disease in the mentally ill, Annals of Internal Medicine, 86, 637-645, 1977

Keeney B.P. Aesthetics of change, Guildford Press, New York, 1983

Kenny D.A., Albright L. Accuracy in interpersonal perception: a social relation analysis, Psychological Bullletin, 102, 390-402, 1987

Knotunerus J.A., Dialectiek van het onderzoek in de huisartsgeneeskunde, Inaugurale rede aan de Rijksuniversiteit Limburg, 1988

Kohle K., Gaus E., Simons C., Westphale C., Integration of the psychosomatic approach with internal medicine: development of concepts and preliminary results of evaluation of doctor-patient interaction, Psychotherapy and Psychosomatics, 38, 221-230, 1982

Koranyi E.K. Morbidity and rate of undiagnosed physical illness in a psychiatric clinic population, Archives of General Psychiatry, 36, 414-419, 1979

Krebber Th.F.W.A., Acute buikpijn in de eerste en tweede lijn, Proefschrift Rijksuniwersiteit Limburg, 1988

Kreitman N., Pearce K.I., Ryle A., The relationship of psychiauric, psychosomatic and organic illness in a generail practice, British Joumal of Psychiaatry, 112, 569-579, 1966

Laing R., Phillipson H., Lee A.L., Interpersonal perception: a theory and a method of research, New York: Springer, 1966

Leff J. et al., A controlled trial of social intervention in the families of schizophrenic patients, British Journal of Psychintry, 141, 121-134, 1982

Lipowski Z.J, Rewiew of consultation psychiatry and psychosomatic medicine: II, clinical aspects, Psychosomatic Medicine, 29, 201-244, 1967 
Lutein F, Kok A.R., Hamel L.F., Poiesz A., Some experiences with a complaint list (HSCL), Nederlands Tijdschrift voor Psychologic, 34, 167-179, 1979

Luteijn F., Hamel L.F., Bouwman T.K. Kok A.R., HSCL The Hopkins Symptom Checklist Manual, Lisse, Swets \& Zeillinger, 1984

Maricle R.A., Hoffman W.F., Bloom J.D., Faulkner L.R., Keepers G.A., The prevalence an significance of medical illness among chronically mentally ill outpatients, Community Mental flealth Journal, $23,2,81-90,1987$

Mcintyre J.S., Romano J. Is there a stethoscope in the house (and is it used)? Archives of General Psychiatry, 34, 1147-1151, 1977

Milders C.F.A., van Tilburg W. (redaktie), Systeemdenken en psychiatrie, Hfdst. 2, 3-19, van Gorcum, Assen, 1988

Patterson C.W., Psychiatrists and physical examinations: a survey, American Journal of Psychiatry, 1.35, $967-968,1978$

Pérez E.L., Rassell J., Extent of teaching of psychosocial medicine in Canadian medical schools, Psychosomatics, 26, 10, 820-822, 1985

Ramsay R.A., Krakowski A.J., Rydzynski Z., Jarosz M. Engelsmann F., Ananth J., International comparison of the prevalence of psychosomatic disorders in schizophrenic patients,

Psychotherapy and Psychosomatics, 38, 206-220, 1982a

Ramsay R.A., Ananth J., Engelsmann F., Krakowski A.J., Wittkower E.D. Ghadirian, Schizophrenia and psychosomatic illness, Journal of Psychosomatic Research, 26, 1, 33-42, 1982b

Ramsay R.A., Engelsman F., Epidemiology of psychosomatic disorders in schizophrenic patients: methodological issues, Psychotherapy, Psychosomatics, 40, 148-157, 1983

Rigby J.C., Oswald A.G., An evaluation of the performing and recording of physical examinations by psychiatric trainces, British Journal of Psychiatry, 150, 533-535, 1987

Roessler R., Greenfield N.S., Incidence of somatic disease in psychiatric patients, Psychosomatic Medicine, $23,413-419,1961$

Romme M.A.J., Kraan H. Rotteveel R., Wat is sociale psychiatrie? Samson, Alphen aan de Rijn, 1981

Romme M.A.J., Escher A.D.M.A.C., Radstake D.W.S., Breuls, M.G.G.J., Een indeling in groepen van patienten met cen langdiurige psychiatrische patientencarrière, Tijdschrift voor Psychiatrie, $4,197$. 211,1987

Romme M.A.J. (ed), Research to practice in community psychiatry, Van Gorcum, Assen/Maastrich, 1988

Rooymans H.G.M., Het begrip "specificiteit" in de psychosomatische geneeskunde, Nederlands Tijdschrift voor Geneeskunde, 118-121, 1974

Rooymans H.G.M., Psychiairie als medisch specialisme I, Nederlands Tijdschrift voor Geneeskunde, 123, $10,380-383,1979 \mathrm{a}$ 
Rooymans H.M.M., Psychiatre als medisch specialisme II; Mederlands Tijaschrift woor Geneeskunde, 123, 11, 411-416, 19796

Rooymans HG.M.s De verwevenheid van somatische en psychische ziekten I Sonatische ziektebeelden bif psiychiatrische patienten, Nederlands Tijdschrift woor Geneeskunde, 127, 51, 2323-2327, 1983

Rotter $3 . B$. Generalised expectancies for internal vs. external control of reinforcement. Psychological Monographs, $80,7-28,1966$

Rotteveel $R_{n}$ Uffing J.T.F., Vries N. de, Romme M.A.J., Valkuilen bij de ambulante hulpverlening aan chronische patienten, Maandblad Geestelijke Volksgezondheid, 9, 954-967, 1988

Ruiter B. dc , Henkelman L., Een onderzoek naar chronische psychiatrische patiënten en hun omgeving, Tijdschrift voor Psychiatrie, 31, 1, 29-37, 1989

Ruiter $\mathrm{C}$. de, Cohen $\mathrm{L}$. De therapeutische alliantie en therapieresultaat, Tijdschrift voor Psychotherapie, $13,255-265,1987$

Sandifer M.G., The education of the psychiatrist as a physician, American Journal of Psychiatry, 1, 5053,1977

Scheff T.J., Toward a sociological model of consensus, American Sociological Rewiew, 12, 32-46, 1967 Shinozaki $\mathbb{H}_{\text {, An }}$ epidemiologicall study of deaths of psychiatric inpatients, Comprehensive Psychiatry, $17,425-436,1976$

Siegler M., Osmond H., Models of madness, models of medicine, MacMillan, New York City " 1974 Sims A., Why the excess mortality from psychiatric intness? British Medical Journal, 412 I-412 II, 1987 Speck $R_{\text {. }}$ V., Attneave $C$. L., Family networks; a new approach to familly problems, New York: Vintage Books, 1973

Strauss J.S., Carpenter W.T., The prediction of outcome in schizophrenia III, Archives of General Psychiatry, 34, 159-163, 1977

Summers W.K., Munoz R.A., Read M.R., The psychiatric physical examination-Part I: methodology, Journal of Clinical Psychiatry, 42, 3, 95-98, 1981

Swinkels H., Gezondheidsenquëtes, trendcijfers gezondheidsenquête, 1981-1987, Maandbericht Gezondheidsstatistiek, 8, 14-28, 1988

White $A_{n} I_{n}$, Barraclough $B_{* 0}$ Benifits and problems of routine laboratory investigation in adult psychiatric admissions ${ }_{n}$ British Journal of Psychiatry, 155, 65-72, 1989

Talbout J.A., Linn L., Renctions of schizophrenics to life-threatening disease, Psychiatric Quarterly, 50 , 218-227, 1978

Test M.A. Stein L.I., Community treatment of the chronic patient" a research overview, Schizophrenia Bulletin, 4, 3, 350-364, 1978

Vazquez-Barquero J.L., Pena C., Diez Manrique J.F., Arenal A., Quinkanal R.G., Samaniego C., The influence of sociocultural factors on the interaction between physical and mental disturbances in a rural community, Social Psychiatry and Psychiatric Epidemiology, 23, 195-201, 1988 
Willson W.H. Jefferson J.W., Thyroid disease, behavior and psychopharmacology, Psychosomatics; 6, 481-493, 1985

Wing IK. Morris B. (eds), Clinical basis of rehabilitation, Handbook of psychiatric rehabilitation practice, England, Oxford University Press, 1981 


\section{DANKWOORD}

Allereerst zou ik mijn promotores willen danken, die bereid zijn geweest gedurende de afgelopen vier jaar een relatie met mij aan te gaan die wel eens is aangeduid als een academisch huwelijk.

Hooggeleerde Philipsen, beste Hans, het begrip continuiteit van zorg heb jij voor wat het tot stand komen van dit proefschrift betreft letterlijk genomen. Vanaf het begin tot aan het einde was je nauwkeurig luisterend en lezend, geduldig de beginselen der statistiek uitleggend aanwezig. Je goed gedoseerde aandacht stimuleerde me tot productief gedrag.

Hooggeleerde Romme, best Marius, $\mathrm{jij}$ gaf me de mogelijkheid onderzoek te doen in de Sociale Psychiatrie door mijn aanstelling bij de RIAGG te bevorderen en mij in jouw lopende onderzoek te betrekken. Met grote voortvarendheid en op jouw karakteristieke flamboyante wijze hielp je mij de vele obstakels die de uitvoering van dit onderzoek in de weg stonden te nemen. Je opstelling als promotor prikkelde me mijn eigen weg te zoeken en te vinden.

Waarde Pomerantz, beste Harry, jij kreeg meestal de financiële academiseringsbrokken van mijn onderzoek onvrijwillig in je schoot geworpen. Je hebt dit lijden grootmoedig en solidair gedragen. Telkens wist je de gepresenteerde stapel rekeningen te voldoen door een afschrijving op het vorige boekjaar. Een onder curatele stelling heb je misschien overwogen, maar gelukkig is het bij een RIAGG salaris inschaling gebleven.

Dit onderzoek had nooit plaats kunnen vinden zonder de medewerking van mijn S.P.D.teamgenoten. Zij vulden stapels vragenlijsten in en ondersteunden en moedigden de deelnemende patiënten aan in het volvoeren van de lichamelijke keuringsprocedure. Enkele teamleden die ik speciaal zou willen noemen zijn Steven Radstake, die aan de basis stond van de academisering van de S.P.D. en de probleemanalyse en voorts Claar Pelzer en Leny Vallenga die als sociaal psychiatrische verpleegkundigen de patienten in het academisch ziekenhuis ontvingen en wegwijs maakten.

Geleerde Weenink en de Wit, beste Anke en Rianne, jullie hebben als student-assistent verbonden aan mijn onderzoeksproject vaak lange uren gemaakt. Jullie wisten mijn bij tijd en wijle wat al te divergente en soms chaotische denken om te zetten in codeboeken en verifieerbare data. Van harte wil ik jullie bedanken voor de geboden hulp.

Zeergeleerde Pop, beste Peter, je kwaliteiten als internist en geroutineerd onderzoeker hebben hun uitwerking op dit onderzoek niet gemist. Je onderzoeksverslagen muntten uit in overzichtelijkheid en helderheid en je conclusies ten aanzien van de geconstateerde pathologie waren slechts voor én uitleg vatbaar. Voor je collegiale opstelling ben ik je dankbaar.

Geleerde Tan, beste Frans, menig uurtje hebben wij samen zitten zweten in jouw werkkamer van $2 \times 2$ meter. Niet alleen om mij de beginsellen van de statistiek bij te brengen maar vaak op een nog basaler nivo om te komen tot een toetsbare onderzoekshypothese. Mijn dank voor jouw geduld.

Beste Mevrouw de Monchy, lieve Jocy, ik zou jou willen bedanken voor de zeer persoonlijke inzet bij het typen en de lay-out van dit manuscript.

Lieve Hanneke, Cees, Piet en Toon, ik ben me ervan bewust dat het niet altijd een feest is geweest om met een promovendus te moeten leven. Door jullie opstelling heb ik er nooit aan getwijfeld dat ons gezin moeiteloos af zou rekenen met het eerder genoemde academische huwelijk. Een goede reden om feest te vieren.

Lieve ouders, het laatste woord is voor jullie. Mijn dank aan jullie kan ik het beste omschrijven met een gedicht van Herman van Veen: "In het bed van mijn ouders zit een kuil en dat ben ik". 


\section{CURRICULUM VITAE}

De schrijver van dit proefschrift werd geboren te Utrecht op 11 oktober 1952 Hij behaalde het HBS-B diploma in 1971. In dat zelfde jaar begon hij zijn studie in de Geneeskunde aan de Rijksuniversiteit te Utrecht, alwaar hij in 1979 werd beedigd tot arts. In het kader wan zijn opleiding tot psychiater was hij gedurende raim een jaar werkzam als arts-assistent in de Neurologie in het Wilhelmina Gasthus te Amsterdam, Universiteit van Amsterdam, gevolgd door drie jaar opleiding in de Psychiatrie in Guy's Hospital Medical School te London, Engeland en een jaar opleiding Psychiatrie in de Psychiatrische Universiteitskliniek te Utrecht.

Tijdens zijn opleiding in London behaalde hij het Membership of the Royal College of Psychiatrists. In 1984 werd hij ingeschreven in het specialistenregister van de Psychiatrie in Nederland.

In dat zelfide jaar trad hij als sociaal psychiater in dienst bij de Sociaal Psychiatrische Dienst van de RIAGG te Maastricht. Sinds 1986 is hij tevens als universitair docent verbonden aan de vakgroep Geestelijke Gezondheidkunde i.o. van de Rijksuniversiteit Limburg.

Behoudens de publikaties voortvloeiend uit dit proefschrift publiceerde hij of was betrokken bij de publikatie van:

A neuroendocrine study of stereotactic sub-caudate tractotomy, T.H. Corn, A. Honig, C. Thompson, P.K. Bridges, J.R. Bartlett, S.A. Checkley British Journal of Psychiatry, 1984, 144, 417-420

Ventricular size, the dexamethasone suppression test and outcome of severe endogenous depression following psychosurgery, H.M.A.S Standish-Barry, A.S Hale, A. Honig, N. Bouras, P.K. Bridges, J.R. Bartlett Acta Psychiatrica Scandinavica, 1985, 72, 166-171

The stalemate position; rehabilitation problems after psychosurgery, A. Honig, P. K. Bridges, J.R. Bartlett The International Journal of Social Psychiatry, 1987, 33, 3, 195-203

Amino acid levels in depression: a preliminary investigation, A. Honig, J.R. Bartlett, N. Bouras, P.K. Bridges Journal of Psychiatric Research, 1988, 22, 3, 159-164 